
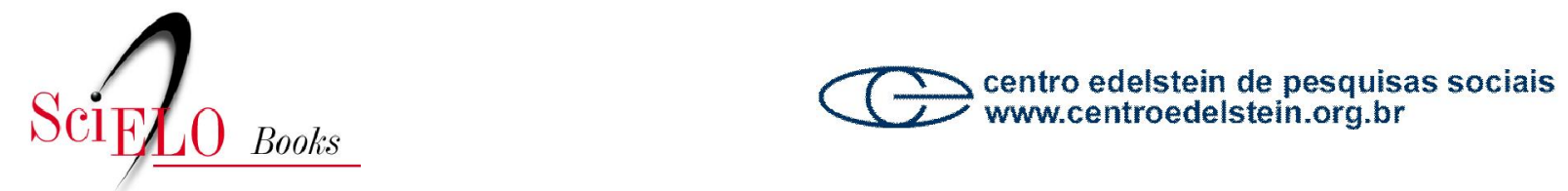

\title{
La democracia inesperada
}

\author{
Bernardo Sorj
}

SORJ, B. La democracia inesperada [online]. Rio de Janeiro: Centro Edelstein de Pesquisa Social, 2008, 94p. ISBN 978-85-99662-56-4. Available from SciELO Books <http://books.scielo.org>.

\section{(1) (1)(2)}

All the contents of this chapter, except where otherwise noted, is licensed under a Creative Commons Attribution-Non Commercial-ShareAlike 3.0 Unported.

Todo o conteúdo deste capítulo, exceto quando houver ressalva, é publicado sob a licença Creative Commons Atribuição Uso Não Comercial - Partilha nos Mesmos Termos 3.0 Não adaptada.

Todo el contenido de este capítulo, excepto donde se indique lo contrario, está bajo licencia de la licencia Creative Commons Reconocimento-NoComercial-CompartirIgual 3.0 Unported. 


\section{LA DEMOCRACIA INESPERADA}

Bernardo Sorj 
Esta publicación es parte de la Biblioteca Virtual de Ciencias Humanas del Centro Edelstein de Investigaciones Socialies - www.bvce.org

Copyright (c) 2008, Bernardo Sorj

Copyright (c) 2008 de esta edición on-line: Centro Edelstein de Investigaciones Sociales

Año de la última edición: 2005

Ninguna parte de esta publicación puede ser reproducida o transmitida por cualquier medio de comunicación para uso comercial sin el permiso escrito de los propietarios de los derechos de autor. La publicación en su conjunto o en parte puede ser reproducida para fines no comerciales a condición de que el origen de la publicación y autor sea debidamente reconocida.

ISBN 978-85-99662-56-4

Centro Edelstein de Investigaciones Sociales www.centroedelstein.org.br/espanol/index.asp Rua Visconde de Pirajá, 330/1205

Ipanema - Rio de Janeiro - RJ

CEP: 22410-000. Brasil

Contacto: bvce@centroedelstein.org.br 


\section{ÍNDICE}

Prólogo

Guillermo O'Donnell

\section{Introducción}

La Paradoja Democrática

\section{Capitulo I}

Ciudadanía y Derechos Humanos

Las diversas ciudadanías

Ciudadanía y las antinomias de los derechos humanos

\section{Capitulo II}

De los Derechos laborales al derecho de las minorías

El pasaje del contrato de trabajo alos derechos sociales

Desigualdad social, mercado y Estado

De la dominación anónima a la fragmentación de los derechos

El nuevo individualismo e identidades colectivas

36

La crísis de representación política y el papel del Poder Judicial

\section{Capitulo III}

La "sociedad civil", las ONGs y la globalización de las agendas sociales 46

La "sociedad civil"

El mundo de las ONGs 54

¿La reconstrucción del mundo por los derechos humanos o por el mercado?

La opinión pública global y los Estados Nacionales

\section{Capitulo IV}

Transformaciones sociales y juridicionalización del conflicto social en América Latina

Ciudadanía en América Latina: variaciones de la modemidad

Individualismo a la latinoamericana

Conclusiones: Política sin moral y moral sin política?

Los desafíos a la democracia

Nota sobre interdisciplinariedad 


\section{Prólogo}

Guillermo O'Donnell

Este es un libro refrescante: no tiene nada trillado, rechaza con fundamento diversos convencionalismos y modas académicas, y no vacila en tomar clara posición en temas espinosos. Con este libro Bernardo Sorj muestra una vez más lo que ya sabíamos los que hemos seguido su trayectoria: no es sólo un excelente sociólogo profesional, es también y sobre todo un verdadero intelectual, un pensador crítico de las grandes cuestiones de nuestro mundo especialmente el Latinoamericano.

Sorj comienza su libro con la pregunta típica de este tipo de íntelectual: “¿Qué tiempos son estos?" Esta pregunta, claro está, dispara el pensamiento en varias direcciones. Pero la búsqueda de Sorj está disciplinada por una tesis principal, que da sentido al título dellibro: "La democracia se consolidó, pero no es Ia democracia esperada." Aunque no creo estar de acuerdo con el concepto de "consolidación", esta tesis marca un desafío que comparto plenamente: para entender nuestros países y con ellos sus democracias hay, primero, que entender los cambios globales y, segundo, detectar la especificidad que ellos adquieren en nuestros países y su pesada herencia de pobreza, desigualdad y autoritarismo socialmente implantado. Vasta tarea, que Sorj emprende con lucidez y a la que hace importantes contribuciones.

A lo largo de esta tarea Sorj desbroza temas que no voy a resumir aquí porque ellos están claramente enunciados en este libro que el autor ha tenido la buena idea de hacer breve. Destaco sin embargo algunos puntos. Uno es la reflexión acerca de la "doble dificultad" que presenta el estudio de la ciudadanía en el contexto latinoamericano, y la acertada crítica que hace a las numerosas obras que (no sólo respecto de la ciudadanía, agrego) sólo pueden concebi $r$ ese estudio como el de una carencia respecto de la imagen (idealizada, por atiadidura) de la ciudadanía en las países capitalistas avanzados. En este plano, Sorj acierta (nuevamente, contra buena parte de la literatura en baga) al afirmar el estrecho vínculo, analítico e histórico, entre por un lado la ciudadanía y, por el otro, el pueblo-nación.

Un segundo punto es que la noción de ciudadanía conduce inexorablemente a la de derechos, pero Sorj argumenta con buenas razones que las derechos no deben ser entendidos sólo en su abstracción sino también, y sobre todo, en su imbricación con las características específicas de nuestras sociedades. Son estas características, como Sorj va a seguir argumentando a lo largo dellibra, las que permiten entender la actual hipertrafia de algunos derechos, la gravosa caducidad de otras y, en general, a través de la evaporación de las funciones prapiamente representativas de 
los partidos políticos, el desmesurado papel del poder judicial en la adjudicación de algunos de esos derechos.

El tercer punto que quiera destacar es que para hacer estas análisis hay que hacer-y hacer muy bien-dos tareas per se complicadas: conocer las teorías relevantes a los respectivos temas y además, conocer las especificidades históricas y sociales de los casos que interesan, para desde allí reconstituir adecuadamente esas teorías. Todo este libra muestra esta, pero setialo el capítulo II ("De los derechos del trabajo al derecho de Ia minorías") como una magistral aplicación de ello.

Mi cuarto comentaria es que, como insinúo arriba, debemos agradecer a Sorj que haya querido lanzar una mirada ponderadamente crítica a diversas versiones idealizadoras de la sociedad civil, de las ONGs y de los derechos humanos; nuestro autor no niega Ia importancia y contribuciones de estas esferas pero no vacila en apuntar los errores-prácticos y teóricos-resultantes de las idealizaciones y moralismos que suelen acompatiar esas versiones. Asimismo, con especial y en mi opinión muy justificado filo crítico, Sorj examina las concepciones (especialmente Ias del Banco Mundial) sobre capital social.

Estas posiciones son abiertamente polémicas. Las comparta uno o no (y yo comparto casi todas ellas), este libra pane e intenta abrir discusión el dominio de la teoría y el informado buceo en la realidad de nuestros países (no sólo Brasil, aunque éste sea el principal referente de este uruguayo y rioplatense al que los vientos de la represión desembarcaron en Brasil hace ya unos veinte atios) permite revelar las numerosas mistificaciones que nublan la percepción de la realidad, y de las posibilidades, de nuestros países.

Por eso digo al comienzo de este breve Prólogo que éste es un libro refrescante. Espero se entienda ahora que he usado este término como un tremendo elogio-que sólo puede culminar en recomendar una lectura tan abierta como la del vigoroso pensamiento de nuestro autor.

Enero 2005 


\section{Introdución}

\section{La paradoja democrática}

Este libro trata del fin de un período histórico y el comienzo de una nueva época, en la que estamos aún dando los primeras pasos y, por tanto, no es fácil capturar sus padrones dominantes. La época que ahora está terminando coincide en buena medida con el siglo XX y fue dominada por el lugar central que en ella ocuparon las clases sociales como factor estructurante de la vida política e ideológica, a partir de los embates entre la burguesía y el proletariado o entre propietarios de tierras y campesinos, desdoblados en sindicatos, partidos socialistas y revoluciones. Se trata de un período donde las reivindicaciones sociales se organizaron como derechos colectivos en tomo al mundo del trabajo, y que se expandieron a través del Estado de bienestar, a otros sectores de la sociedad.

Visión del mundo sustentada en un trípode en cuyo vértice se encontraban las clases sociales como organizadoras de la estructura social, el sindicato como principal estructurador de los intereses de los trabajadores y el partido político como formulador de las utopías sociales ha perdido su actualidad. Las transformaciones del capitalismo y la derrota del comunismo diluyeron el papel estructurador de las clases sociales, disminuyeron la importancia de los sindicatos y fragilizaron los partidos políticos en general y los de izquierda en particular.

El anti-liberalismo no puede ser un alibi intelectual para dejar de responder a Ia cuestión: tqué nuevos tiempos son estos? La respuesta de este ensayo es que vivimos en sociedades cada vez más democráticas, en las que los valores igualitarios se profundizan al tiempo que avanza la desigualdad social. La democratización de los valores y expectativas a través de la expansión de los sistemas de comunicación, la consolidación del individualismo y de la sociedad de consumo, el debilitamiento de las jerarquías sociales, el fortalecimiento de la llamada "sociedad civil" y la diseminación del discurso de los derechos humanos han venido fomentando el sentimiento compartido de interdependencia y de común humanidad entre todos los habitantes del planeta. Sin embargo, aumentan también las dificultades de los regímenes democráticos para dar cuenta de la creciente desigualdad socioeconómica y enfrentar la multiplicación de los problemas sociales, en particular, de la violencia. En América Latina, esa contradicción adquiere una magnitud particular en razón de las expectativas desencadenadas por el proceso de democratización.

La democracia se consolidó, pero no es la democracia esperada. Este ensayo busca explorar los por qué de la democracia inesperada, centrándose en el análisis de cómo ella se construyó en relación a la dinámica social, a la individualización, a la democratización de las relaciones sociales 
y a la transformación de los mecanismos de representación política.

Para entender las tendencias del presente, es necesario, antes que nada, comprender qué es lo que cambió. La situación actual es el resultado fundamentalmente de una nueva dinámica de individualización y de constitución de identidades colectivas y de participación política, tendiente a fragmentar la representación social y a limitar la capacidad de elaboración de propu estas para la transformación del conjunto de la sociedad. A partir de estos procesos debemos entonces de analizar las relaciones entre el nuevo asociativismo y el surgimiento de nuevos actores colectivos en un contexto de refiujo del movimiento obrero y de los ideales socialistas. Se trata de reconocer la complejidad de los procesos históricos, mostrando las consecuencias imprevisibles y no intencionales de la acción social, sin caer en una visión maniqueísta y conspirativade la historia, donde todos los caminos conducen a Washington y todas las nuevas formas de creatividad y acción social son reducidas a factores funcionalizados por el poder hegemónico. ${ }^{1}$

La actual crisis de representación política es producto del creciente distanciamiento entre Ios partidos políticos y las ONGs -los nuevos vectores de demandas solidarias-, de la valoración del discurso de los derechos humanos (acompafiada por la perspectiva simplificadora de los medios de comunicación de masas), de la afirmación moralista de valores disociados de intereses y, finalmente, del discurso que solo valoriza al mercado. Tanto este último, como el discurso centrado en los derechos humanos, excluyen de la vida política la explicitación de los intereses socioeconómicos y su lugar en Ias estructuras de poder.

La "sociedad civil" y los nuevos actores sociales construyen sus identidades en torno a reivindicaciones referidas alos derechos humanos vehiculados por el sistema constitucional, por Ias ONGs y por organizaciones internacionales-, al margen, en general, de las instituciones políticopartidarias. Aunque la acumulación de derechos fortalezca el sentimiento de dignidad de diversos grupos, el resultado de las demandas realizadas por los nuevos actores sociales se ha revelado extremadamente ineficaz en términos de la disminución de la desigualdad socioeconómica del conjunto de Ia sociedad.

El pasaje del mundo de los derechos al mundo de la política implica negociaciones y elecciones, supone movilización de intereses conflictivos, acuerdos y administración de recursos escasos. En suma, se trata del pasaje del mundo ideal al mundo de la necesidad. A medida que las nuevas formas de acción colectiva se sustentan o bien en el discurso de los derechos humanos o

\footnotetext{
${ }^{1}$ Como es el caso, por ejemplo, de muchos científicos sociales, algunos de los cuales inspirados en Pierre Bourdieu, que reducen toda nueva forma acción social a un proceso de eterno retorno de elites cooptadas por el sistema de poder. Se trata de cierta forma de una visión pareteana de la historia presentada con un lenguaje crítico pero no por eso menos reaccionaria, pues incapaz de captar los cambios históricos. Dentro de esta perspectiva, sobre el tema de los s derechos humanos y América Latina ver Yvez Dezalay, Bryant G. Garth, The Internationalization of Palace Wars -Lawyers, Economists, and the Contest to Transform Latin American States, The University of Chicago Press, Chicago, 2002.
} 
bien en fundamentalismos religiosos -cuyas demandas, en ambos casos, son de carácter moral, esto es, contienen reivindicaciones de valor absoluto y no negociables- ellas dificultan la cristalización de proyectos político-partidarios, provocando así un distanciamiento entre moral y política, entre derechos e intereses.

El proceso de creación de nuevos derechos y de nuevos sujetos de derecho vino a transferir hacia el orden jurídico y al Poder Judicial demandas y expectativas de distribución de riqueza y de reconocimiento social. Los nuevos derechos funcionan, ocasionalmente, como derechos por default; o sea, en vez de ser efectivamente acumulativos, son utilizados por los actores sociales para suplir carencias producidas por las insuficiencias y a veces, por la mera supresión- de los "antiguos" derechos sociales.

Así la juridicionalización del conflicto social y los nuevos actores sociales tienen una limitada eficacia como instrumento de disminución de la desigualdad social, pues fragmentan la representación de intereses a nichos, sin disponer de una visión de conjunto de la sociedad, fragilizando la política partidaria, substitui da por nuevos actores, especialmente ONGs, cuyas reivindicaciones alcanzan, en general, un impacto mas simbólico que práctico, sustrayéndole a los partidos políticos la representación del discurso moral y la elaboración de nuevas utopías sociales. Las presiones y expectativas crecientes transferidas al Poder judicial dejan al descubierto los límites de dicho poder para resolver problemas que exigen respuestas ejecutivas o administrativas; respuestas que, en una sociedad democrática, están fuera de su alcance y de sus posibilidades funcionales. La explicitación de tales limitaciones desestabiliza al Poder judicial, que tiende a dividirse en razón de su identificación con los diversos grupos sociales cuyos intereses dependen de sus decisiones. A su vez, las ONGs, aun teniendo un creciente poder de movilización de Ia opinión pública, son bastante limitadas como instrumento de presión política, evidenciando un déficit de legitimidad al no poseer ni mandato ni representación social definida.

El lugar que los derechos humanos ocupan como ideología común, en torno al cual se organizan los diversos discursos políticos contemporáneos, la transformación creciente del Poder Judicial en árbitro de conflictos sociales y el papel de un sistema de regulación de derechos que trasciende las fronteras nacionales, exigen repensar el sistema de instituciones sobre las cuales ser erigió el Estado Nacional, con una división más o menos definida de poderes y de mecanismos de resolución de conflictos. En el nuevo contexto, la política se juridicionaliza, el Poder judicial se constitucionaliza y las constituciones se construyen en torno a valores sustentados por una opinión pública crecientemente globalizada no enmarcada por las fronteras nacionales.

Las nuevas formas de participación social en torno a causas "inmateriales" (esto es, no referidas a relaciones de poder ni a intereses socioeconómicos precisos), como, por ejemplo, la 
ecología, el feminismo, la raza o la etnia, fragmentan la participación social y colaboran al distanciamiento de una visión de la sociedad nacional. Lo cual disminuye el papel de la representación partidaria pues las políticas públicas pasan a apuntar a blancos cada vez más fragmentados.

Eldesarrollo de la "paradoja democrática" - crecimiento de la expectativas igualitarias junto con el aumento simultáneo de la desigualdad social - está asociado, como veremos, más que a un programa específico de políticas económicas, al contexto de transformación de las sociedades, los procesos de globalización y a la influencia creciente del modelo societario norteamericano. Tal influencia, con todo, se construyó a partir de afinidades electivas y de acomodamientos entre los procesos sociales e institucionales internos a cada sociedad nacional y los modelos disponibles de construcción institucional en el plano global. En ese contexto es indudable la capacidad política de los Estados Unidos, y en menor medida Europa, para imponer modelos institucionales, directa o indirectamente, a través de organismos financieros internacionales o de fundaciones privadas.

Pero es en el interior de las sociedades nacionales que se deben capturar los mecanismos por los cuales la desigualdad se reproduce, pues las fuerzas externas o las tendencias globalizantes son absorbidas por el sistema institucional nacional. Sin dejar de contemplar la relevancia, ciertamente diversa en cada caso concreto, de la acción de factores ligados a la globalización y a la implantación del modelo económico neoliberal, no podemos olvidar que los niveles de desigualdad social de los países de la América Latina presentan una impresionante estabilidad a lo largo del tiempo. Así, la globalización no puede ser una justificación para abandonar el estudio de la dinámica institucional de las sociedades nacionales, que siguen siendo el principal espacio de sociabilidad, de las oportunidades de vida y de destino personal de la mayoría de la población.

La legitimidad de la acción pública en los sistemas políticos contemporáneos, sean nacionales o internacionales, se sustenta en el discurso de los derechos humanos. Una vez que dicho discurso representa el horizonte normativo del pensamiento democrático actual, la crítica a sus fundamentos se ha limitado, al interior de la tradición moderna, a una relativización del mundo de los derechos humanos como un sistema cultural entre otros posibles. No es, con todo, una discusión filosófica la que nos interesa desarrollar en este libro. Nuestra problemática remite más bien a la apropiación política de los derechos humanos por las organizaciones e instituciones sociales. La cuestión sociológica levantada por el discurso de los derechos humanos no se refiere, por tanto, a sus eventuales limitaciones epistemológicas o a sus contradicciones internas, sino a los usos que diferentes actores sociales hacen de él y a sus consecuencias políticas.

A partir de la especialidad del autor, la sociología, estimamos pertinente vincular dos disciplinas: la sociología y los estudios jurídicos. Mi búsqueda de diálogo interdisciplinario ha sido 
construida, en buena medida, a partir de un concepto central tanto para el sentido común como para la sociología y las ciencias jurídicas: el de ciudadanía. Así, este libro puede ser leído como un esfuerzo de reconstrucción crítica de tal concepto, destinado a mostrar las razones y las consecuencias de su asociación con, prácticamente, todos los movimientos reivindicativos a punto de banalizarse. Entender la ciudadanía, sus fundamentos y límites, como mecanismo central de auto-representación de los individuos en la sociedad moderna deberá permitir no sólo su uso más riguroso en las ciencias sociales -de suyo tendientes a mimetizarse con el sentido común- sino también indicar las problemáticas consecuencias de la extensión de la "ciudadanía" a cualquier reivindicación de derechos, extensión que destruye su sentido específico, esto es, su significado como derechos básicos que aseguran la vida democrática. Esa banalización está enralzada, como veremos, en los procesos sociales de fragmentación de Ia vida política y en Ia pérdida de horizonte de los proyectos societarios inclusivos.

La América latina debe ser vista como un laboratorio para la teoría social, pues los procesos aquí analizados están presentes en todas las sociedades capitalistas democráticas. En el caso latino americano, dichos procesos son conducidos al paroxismo por su articulación con una tendencia enralzada históricamente en diversas corrientes ideológicas del continente, tanto de derecha como de izquierda, a saber: la desvalorización del orden jurídico y del poder judicial. La novedad es que esta crítica hoy en día ya no es realizada, como antiguamente se hacía, en nombre de otras ideologías, ya sea de corte autoritario o de modelos alternativos de sociedad, sino en nombre de los propios derechos humanos, consubstanciados con el orden jurídico. Hasta aquéllos que critican la globalización y el "neoliberalismo" lo hacen en nombre del mismo repertorio de derechos humanos compartido por los defensores de la llamada globalización neoliberal.

Somos concientes de los riesgos que corremos al hacer generaliza ciones sobre América latina y otros continentes, aunque no dejamos de seflalar, en Ia medida de lo posible, la diversidad de las situaciones nacionales. Esperamos que las hipótesis presentadas — a partir de un recorte de la realidad que, haciendo honor al destino del análisis social, está llamado a explicar sólo una parte de la dinámica de la sociedad, dejando en penumbra otros fenómenos igualmente fundam entales puedan abrir paso a futuros estudios de caso.

Finalmente nos gustaría seflalar que las ideas aquí presentadas son producto de discusiones desarrolladas en los seminarios ofrecidos con Jean Michel Blanquer en el Institut des Hautes Études de l'Amérique Latine (IHEAL) y com Daniel Pécaut na École des Hautes Études en Sciences Sociales. A ambos agradezco su amistad y su apoyo intelectual. 


\section{Capitulo I}

\section{Ciudadanía y Derechos Humanos}

El estudio de la ciudadanía revela, en el contexto latinoamericano, una doble dificultad. La primera, a la cual están some tidos todos aque1los que trabajan con ese concepto, es de carácter general, ya que el mismo contiene una referencia tanto empírica como normativa. la referencia empírica com prende la ciudadanía tal como ella se manifiesta en cada contexto histórico o social; la referencia normativa remite, en cambio, a la ciudadanía como ideal, tal como ella es explicitada generalmente en las constituciones, y representada en los sentimientos, expectativas y valores, más o menos difusos, de los agentes sociales. La segunda dificultad es que, en el contexto latinoamericano, esa "bi-valencia" (muchas veces fuente de ambivalencia y de confusión analítica) acumula un segundo registro de referencias empíricas y normativas. Cuando las ciencias sociales en América latina (así como las ideologías políticas o el sentido común) se refieren a una ciudadanía ideal, lo hacen teniendo como trasfondo mental, implícita o explícitamente, las experiencias concretas de ciudadanía de los países avanzados, transformándolas de un mundo empírico en un mundo idealizado.

Al tomar como referencia ideal la ciudadanía real que existe o existió en Europa o en Estados Unidos, el análisis social entra en un juego de espejos, del cual es difícil liberarse, pues genera múltiples confusiones entre lo ideal y lo real, entre lo normativo y lo empírico, ya que mezcla el ideal con realidades históricas complejas y en plena mutación. Así, los científicos sociales son llevados a explicar — según una visión idealizada y homogenizadora de esos países, desconocedora de la diversidad y los percances de las trayectorias nacionales — por qué no llegamos a tener ciertas características que serían típicas de los países desarrollados ${ }^{2}$.

Si modelos institucionales de América latina fueron, en general, importados, los modelos "originales", a su vez, fueron influenciados por varias experiencias nacionales habiendo sufrido permanentes procesos de transformación. La construcción de la ciudadanía, ya sea en Francia o en los Estados Unidos, en Japón o en Alemania, fue, y continúa siendo, un proceso complejo, sufrido, zigzagueante, irreductible a una perspectiva estática y estilizada de cómo se presentó en las últimas décadas del siglo xx. Todo lo cual no autoriza, en definitiva, una simple contraposición entre una relativa homogeneidad de las instituciones democráticas de los países centrales (vista desde la periferia) y las dificultades vividas por los países en desarrollo. Además, junto a la errónea

\footnotetext{
${ }^{2}$ Para una discución más detallada de esta problemática, ver Bernardo Sorj, "Crises e horizontes das ciências socials na América Latina".
} 
utilización de las experiencias históricas concretas, las ciencias sociales de América Latina también tienden a movilizar modelos teóricos normativos de ciudadanía, elaborados en los países desarrollados, acudiendo a construcciones abstractas, desconectadas de las fuentes históricas y culturales originarias.

La consecuencia más nociva de la representación de la ciudadanía de los países desarrollados como un mundo ideal y deseable, es su contraposición a una imagen de la ciudadanía de los países latinoamericanos como un mundo de carencias y mistificaciones, como un reino de desigualdad y de arbitrariedad. Ese maniqueísmo analítico contribuyó a construir así una doble imagen irreal: la de los países avanzados y la de los países en desarrollo; en lugar de mostrar contrastes y complejidades, el análisis social se metamorfosea en denuncia y demonización. Muchos estudios en ciencias sociales, en lugar de descubrir las formas y los sentidos de la construcción social de la ciudadanía, a partir de los propios agentes sociales, reflejan las frustraciones de la intelectualidad y de las clases medias locales con sus propias sociedades. Tal actitud, aunque comprensible, alimenta una secular tendencia a la desmoralización de Ias instituciones democráticas existentes, mientras las ciencias sociales pierden la oportunidad de mostrar que América Latina es una cantera de experiencias sociales que, considerada con los debidos cuidados, plantea problemas teóricos y prácticos igualmente relevantes para los países capitalistas avanzados.

\section{Las diversas ciudadanias}

El desafio que el concepto de ciudadanía presenta para las ciencias sociales es el de distinguir entre el significado que le asignara el sentido común, con una 'fuerte carga normativa, y una noción más rigurosa, provista de un valor empírico-analítico. Se trata de un problema particularmente agudo en América Latina, donde, en las últimas décadas, la ciudadanía o el "acceso a la ciudadanía" se transformó en "acceso al mundo ideal", siendo utilizado en ese sentido por la generalidad de los movimientos sociales, por las ONGs, así como por empresas ("empresas-ciudadanas"), organismos internacionales y políticas públicas. La ciudadanía, en consecuencia, pasó a ser polisémica y a tener connotaciones fundamentalmente normativas.

El primer paso a dar para deslindar el concepto de ciudadanía consiste en insertarlo en la dinámica de cada sociedad históricamente determinada, dentro de la cual dicho concepto adquiere características específicas. Aquí nos interesa caracterizar la ciudadanía en las sociedades modernas. Ahora bien; en el mundo moderno, la ciudadanía siempre estuvo asociada a diferentes formas de sociedad y de régimen político (por ejemplo, fascista, comunista o religioso integrista). Una segunda especificación consiste entonces en indicar que 
nuestro análisis se centra en la ciudadanía de los países capitalistas de democracia liberal. Como aún en estos países la ciudadanía presenta una diversidad histórica y nacional muy grande, es necesario identificar la variedad de mecanismos institucionales que ella contiene, así como las formas propias que ella exhibe en la América Latina contemporánea.

El peligro de este procedimiento es el de caer en un relativismo, según el cual existiría una infinidad de "ciudadanías". Se trata por lo tanto de distinguir, mediante el análisis teórico y comparativo, cuáles son, en cada momento histórico y en cada cuadro societario, los componentes básicos comunes que constituyen las precondiciones de la existencia de una ciudadanía democrático-liberal, sin los cuales sería inimaginable la posibilidad de la ciudadanía en una sociedad capitalista democrática.

La ciudadanía en el mundo moderno es, en primer lugar, un mecanismo de inclusión/exclusión, una forma de delimitación de quién es parte integrante de una comunidad nacional. Por lo tanto, la ciudadanía es expresión de una construcción colectiva que organiza las relaciones entre los sujetos sociales, formados en el propio proceso de definición de quién es, y quién no es, miembro pleno de una sociedad políticamente organizada. Ese carácter adscriptivo de la ciudadanía es generalmente ignorado toda vez que ella es definida en términos de derechos individuales. La ciudadanía es una institución que ofrece un título de propiedad particular; un boleto de entrada para una comunidad nacional, el cual da acceso a un conjunto de derechos - boleto que se obtiene, por cierto, mediante un sistema de criterios (por ejemplo, lugar de nacimiento y nacionalidad de los progenitores) distribuidos por el poder constituido. Así, el acceso a la ciudadanía es el filtro que define quién puede participar del sistema de derechos políticos y sociales de cada nación.

En segundo lugar, la ciudadanía supone la existencia de una comunidad cultural y social asociada a una identidad nacional. O sea, la ciudadanía está asociada a la expectativa de compartir la(s) lengua(s), los usos y costumbres de la nación (en sus diversas variaciones regionales o sociales) así como el sentimiento de un destino común. La expresión clásica de tal sentimiento es el servicio militar basado en un reclutamiento universal, ligado a la disposición de morir por la patria. Esa innovación surgió con la Revolución Francesa y permitió transformar, a partir del inventor de las guerras patrióticas imperialistas, Napoleón Bonaparte, el conjunto de los ciudadanos en carne de cafión para aventuras militares, que culminaran en dos guerras mundiales.

Aunque la dimensión nacional de la ciudadanía se encuentre, como veremos, crecientemente cuestionada y en crisis -baste sefialar, como sefial de los tiempos, la profesionalización de los ejércitos y el fin del reclutamiento obligatorio-, lo cual genera tensiones entre la ciudadanía y la comunidad nacional, la ciudadanía como identidad construida sobre una comunidad histórico- 
cultural es todavía una constante de los tiempos modernos ${ }^{3}$.

Allado de la família, la ciudadanía es el punto de filiación inicial del hombre-mujer modernos, define las coordenadas básicas de su identidad, su origen y su lugar en el mundo. Durante largo tiempo la nacionalidad fue tomada como un dato natural, y el cuestionamiento que introdujeran las ideologías igualitarias se centró en la distribución desigual de la riqueza familiar entre aquellos que nacían dentro de cada sociedad nacional. En el actual mundo globalizado, la percepción del origen de la desigualdad social se asocia cada vez más al destino arbitrario de haber nacido en un país y no en otro, y no tanto a las diferentes posibilidades de acceso a la riqueza social, determinadas por el destino, igualmente arbitraria, de haber nacido en el seno de una determinada família. Por lo tanto, en la nueva percepción del mundo globalizado, la ciudadanía es una propiedad desigualmente distribuida y el principal elemento estratificador de las oportunidades de vida de kas habitantes del mundo globalizado contemporáneo. El meta fundamento social de la ciudadania moderna es la dupla individuo-nación o individuo-pueblo. El ciudadano se constituyó como individuo en tanto parte de una comunidad dentro de la cual se reconoce y es reconocido como un igual. Entre los polos individuo-comunidad discurre una tensión -ya expresada en los ajetreos de la Revolución Francesa ${ }^{4}$ - desdoblada constantemente en el conflicto entre los que priorizan Ia libertad individual y aquéllos que sustentan el valor de la igualdad y o de la fraternidad.

Los componentes de la dupla individuo-nación no mantienen entre si una relación de exterioridad. El individuo es, simultáneamente, una singularidad -tendi ente a maximizar sus intereses personales mediante el uso de su racionalidad instrumental- y parte también de una comunidad sociocultural dotada de un sistema de valores y de sentido de pertenencia, en la que encuentra las motivaciones y el contexto social sobre el cual ejerce su capacidad reflexiva y sus estrategias de inserción social. O sea, autonomia y libertad individual adquieren sentido y pueden existir a partir de un sustrato comunitario, el cual implica valores comunes. Si el individuo presupone la comunidad, a su vez la comunidad moderna en sociedades democráticas. Sólo puede existir como expresión de la voluntad de individuos libres.

La formación de la "comunidad nacional" fue un proceso múltiple, en el cuallas lenguas, los dialectos y las lealtades transnacionales fueron reprimidas, modificadas o substituidas por una cultura homogénea, en la que figuraba, en primer lugar, la "lealtad a la patria". Instituciones asociadas al Antiguo Régimen adquirieron nuevo significado y fueron integradas a la lógica de la nueva sociedad. Uno de los ejemplos más expresivos de esto último fue la redefinición de la

\footnotetext{
${ }^{3}$ Ver Dominique Schnapper, La communauté des citoyens. Ver también, en el capítulo 5 de Phillip Bobbit, The Shield of Achilles, un cuestionamiento de la actualidad de ese tipo de análisis.

4 Ver, por ejemplo, Ladan Boroumand, La Guerre des príncipes.
} 
institución matrimonial y del lugar de la mujer. Los principios del liberalismo no se avenían bien con un contrato vitalicio y con el papel subordinado de la mujer. La Revolución Francesa y el Código Napoleónico resolvieron el problema al transformar a la familia y a la mujer en soporte de la comunidad nacional, cuya responsabilidad sería engendrar los futuros ciudadanos-soldados y ciudadanas-madres $^{5}$, así como cuidar de ellos. La subordinación de la mujer a las necesidades de la comunidad nacional la transformó en Marianne, símbolo de la nación: la figura femenina se convirtió en la principal forma de representación visual de la patria. Sólo mediante un largo proceso de luchas sociales las mujeres consiguieron constituirse en individuos y disociarse del papel de reproductoras al servicio de la nación.

La ciudadanía es, por tanto, un concepto resbaladizo, una especie de "bisagra", que se sitúa en el punto de encuentro entre el individuo y la comunidad, siendo el mecanismo que permite al individuo reivindicar su condición singular o su libertad personal y a la vez afirmar su pertenencia al grupo. La pertenencia implica reconocer que su individualidad depende de los rumbos de la comunidad (o de la sociedad nacional), ya que el destino del conjunto afectará su propio destino y Ia ciudadanía no puede ser pasiva o auto-referente, aún en el caso de limitarse a la defensa de la libertad individual. En las sociedades democráticas, la esfera pública es el espacio político en el que se produce el pasaje de la voluntad individual a la voluntad colectiva, el lugar donde los individuos negocian sus intereses personales y sus representaciones del bien común.

La dupla individuo-nación nos remite también a diferentes tradiciones de construcción de la ciudadanía, en particular, a dos grandes vertientes: la Revolución Norteamericana y la Revolución Francesa. Mientras la primera postula un carácter fundamentalmente político -ya que su objetivo central fue asegurar alos ciudadanos la protección frente al Estado, para que cada individuo usufructuase al máximo de su libertad" la segunda procuró reconstruir el orden social, confiriéndole al Estado un papel activo en la realización de los valores comunes de la sociedad ${ }^{6}$. La Revolución Norteamericana está asociada a la tradición liberal, a un especial énfasis en el individuo y a una desconfianza hacia el Estado, mientras que la Revolución Francesa nos remite a la tradición republicana, en la cual son fundamentales la participación política y el papel activo del Estado como expresión de la voluntad del pueblo y como garante de los valores de solidaridad y fraternidad, vehiculados por un conjunto de instituciones sociales (en particular la escuela). A esas dos visiones se agregó posteriormente el socialismo-republicano, cuyos valores de igualdad tuvieron como principal promotor y sustentación a la clase obrera.

\footnotetext{
${ }^{5}$ Ver Ignacio Terradas, "Familia y ciudadanla en la Revolución Francesa".

${ }^{6}$ Un interesante análisis comparativo de las revoluciones de 1776 y 1989, en el que se confrontan las posiciones de Hannah Arendt y de Habermas, puede encontrarse en Antonio Negri" O poder constituinte, cap. 1, p. 24-41.
} 
Los dos principios entrelazados — el de la comunidad y el del individuo — sostienen las dos ideas fundadoras de la ciudadanía moderna: la soberanía del pueblo y la igualdad de los ciudadanos ante la ley. El principio de comunidad implicó una ruptura radical con la tradición según la cual el poder temporal sería expresión de la voluntad divina o de algún otro fundamento trascendental. ${ }^{7}$ En la visión moderna, el poder y las leyes son representados como emanación de la propia sociedad, y sus eventuales representantes ejercen el poder por delegación del pueblo. El principio del individuo significó que la nueva entidad soberana, el pueblo, se apoyara en individuos iguales ante la ley, provistos con la misma parcela de derechos y obligaciones.

La ciudadanía es una realidad histórica y, como tal, fue transformándose con el correr del tiempo, a medida que fuera absorbida por sociedades con tradiciones y estructuras sociales diversas. A pesar de la gran variedad de experiencias concretas, o a causa de ellas, se desarrollaron modelos teóricos que buscan sintetizar la trayectoria de la ciudadanía. El modelo de T.H. Marshall ${ }^{8}$, el más difundido, continúa siendo, pese a las innumerables críticas que padeciera, una referencia para buena parte de la bibliografía especializada, en particular, para la de origen anglosajón, razón por la cualle dispensaremos un tratamiento más detallado.

Según Marshall, la ciudadanía tuvo como motor la expansión del ideal de igualdad de Ia esfera jurídica hacia la esfera política y social. La igualdad ante la ley habría promovido la lucha por la igualdad en las condiciones de participación política (el voto uníversal), y ésta habría permitido el avance de los derechos sociales. Para Marshall, la ciudadanía social en el capitalismo se fundamenta a partir de la contradicción entre el sistema legal y político, llamado a asegurar la igualdad entre los ciudadanos, y el sistema económico, fundado en la desigualdad de acceso a la propiedad. Los derechos políticos, y posteriormente los derechos sociales, permitirían compensar el defasaje entre los dos sistemas, objetivando no tanto la igualación socioeconómica de los ciudadanos, sino la igualdad de oportunidades, la seguridad mínima y la protección alos sectores más frágiles de la sociedad (ninos, deficientes mentales, enfermos, desempleados).

El modelo de Marshall fue criticado por considerarlo como una generalización abusiva de una experiencia particular — la británica —, por su visión evolucionista unilineal, por su optimismo ingenuo y por su fatalismo histórico (téngase en cuenta que, si bien alternativas al modelo liberalsocial-democrático, como el nazismo y el comunismo, fueron derrotadas, ese destino, como indica Mann", no estaba predeterminado). Marshall no previó igualmente otros tipos de derechos (como los ecológicos, los culturales y los de las minorías sexuales), ni la crisis del Estado de bienestar que

\footnotetext{
${ }^{7}$ Como lo muestra Marcel Gauehet en La religion dan la démocratie: parcours de la la cité. 8 Ver T.H. Marshall, Citizenship and Social Class and Other Essays.

${ }^{9}$ Michael Mann, "Rulling Class Strategies and Citizenship". Ver también, entre atras, Martin Bulmer y Anthany Ress (eds.), Citizenship Today; Bryan Turner, "Outline af a Theary af Citizenship".
} 
se desencadenaría dos décadas después de la divulgación de su famosa conferencia.

El trabajo de Marshall es ampliamente utilizado en los estudios sobre la ciudadanía en América Latina para mostrar que los procesos de formación de los derechos en el continente fueron totalmente distintos alos europeos. El problema es que el modelo estilizado de Marshall no puede ser reproducido, en la práctica, en ningún país europeo, no sólo en los países mediterráneos (en Espana, Italia, y Portugal buena parte de los "derechos sociales" fueron implantados por regímenes autoritarios), sino tampoco en Alemania, donde los derechos sociales fueron la invención de un sistema político que no había universalizado aún los derechos civiles. Incluso en el Reino Unido, el avance de los derechos no fue un proceso endógeno natural, sino que estuvo asociado a las transformaciones sociales producidas por su participación en las dos guerras mundiales y al prestigio que la Unión Soviética le transfiriera al Partido Laborista, en las elecciones de 1944. En Estados Unidos, la plena integración civil de los negros fue posterior a la implantación de las políticas sociales del gobierno de Franklin Roosvelt.

Por lo tanto, si la experiencia de América Latina no concuerda con el modelo ideado por Marshall, ello no representa una anomalía que necesite ser explicada como tal todos los procesos de formación de ciudadanía son particulares, así como la estructura económica del capitalismo de cada país presenta sus propios matices.

El principal problema teórico que Marshall, por cierto, no enfrentó, fue el de la compleja relación entre los diferentes derechos. En lugar de un proceso de armonización de valores igualitarios, la historia de los derechos del ciudadano presenta, desde sus orígenes, una constante tensión en torno a la posibilidad de armonizar los variados tipos de reivindicaciones, surgi das permanentemente a partir de las transformaciones sociales y de las nuevas apropiaciones e interpretaciones del discurso de los derechos humanos.

\section{Ciudadania y las antinomias de los derechos humanos}

Como indica Bobbio ${ }^{10}$, los diversos tipos de derechos (legales, políticos, sociales) expresan diferentes tipos de relación entre el ciudadano y el Estado. Mientras que los derechos civiles se desarrollaron fundamentalmente como mecanismos de defensa del ciudadano contra el poder discrecional del Estado, los derechos políticos son expresión de la integración/participación del ciudadano dentro del Estado, y los derechos sociales contienen finalmente demandas del ciudadano al Estado. Desde el punto de vista sociológico, esa dinámica de formación de derechos revela un proceso de institucionalización de mecanismos de integración de aquellos grupos sociales que el

\footnotetext{
${ }^{10}$ Norberto Bobbio, A era dos direitos.
} 
capitalismo, inicialmente, condenara a la subordinación y/o a la pobreza.

Diferentes derechos están asociados a diferentes valores, y su implementación puede significar, nuevamente siguiendo a Bobbio, antinomias. Por ejemplo, el derecho de propiedad puede entrar en contradicción con derechos distributivos, el derecho de fumar o de drogarse puede estar en desacuerdo con políticas de salud pública, el derecho a la información puede divergir del derecho a la privacidad y así sucesivamente. El carácter antinómico de los derechos debió encontrar una solución coherente en el plano del ordenamiento jurídico, en particular en las sociedades modernas regi das por el Código Napoleónico, en las cuales la voluntad de monopolización del Derecho por parte del Estado estuvo asociada a una sistematización y completud del ordenamiento jurídico, en el que al juez apenas le cabe la función de aplicar las leyes. Ocurre que, como veremos, a medida que los derechos se fueron diversificando, aumentó el espacio discrecional del juez o de las cortes constitucionales como última línea de interpretación y de decisión en cuanto al orden de prioridades de los valores expresados por la legislación.

Es importante senalar que el carácter antinómico de los derechos se manifiesta en los problemas de aplicación de valores considerados como absolutos. Lo cual debe distinguirse de las antinomias políticas, esto es, del juego de intereses y de la percepción que los actores tienen del impacto de esos valores. Así, tanto el pasaje de la ciudadanía civil a la política como de la ciudadanía política a la social sembraron el pánico entre una parte de las clases dominantes, temerosas de que el voto universal o de que los nuevos derechos sociales significasen el fin de la propiedad privada. La historia del capitalismo liberal, y en particular, aunque no solamente, de América Latina, está llena de tentativas por limitar el acceso universal al voto y de golpes de Estado desconocedores de la voluntad de las urnas.

El reconocimiento de las consecuencias antinómicas de la aplicación de valores que sustentan los diferentes derechos es fundamental para com prender la dinámica política, social e ideológica de la modernidad; indica la necesidad de no confundir derechos (como sistema de valores) con Derecho (como ordenamiento jurídico). Este último siempre representará una solución, de carácter práctico y más bien precaria, de armonización de valores antinómicos y, por tanto, consistirá en un esfuerzo por delimitar y jerarquizar valores expresados en los "derechos", en sentido genérico, valores que poseen, cada uno de ellos, un carácter absoluto desde el punto de vista ético.

En la base de la antinomia de valores de los derechos humanos se encuentra una doble reivindicación fundadora de la modernidad: la del pleno ejercicio de la libertad individual y la de igualdad entre todos los ciudadanos dentro de una comunidad nacional. La primera supone valores individualistas, mientras la segunda implica valores supra-individuales solidarios; la primera supone 
un Estado que vele por asegurar la libertad de cada uno, y la segunda, un Estado que garantice el acceso de los más desfavorecidos a las condiciones mínimas de integración en la vida social.

Históricamente, fueron las clases propietarias las que procuraron limitar el programa de la modernidad capitalista a la defensa de la libertad individual, mientras las clases populares levantaron la bandera de la igualdad y de la justicia social. Cómo ampliar los intereses com unes sin disminuir ni destruir las libertades individuales es el dilema constitutivo de la modernidad liberal, dilema para el cuallos filósofos, cientistas políticos e ideólogos han buscado respuestas definitivas, pero cuya solución será siempre precaria y cambiante. Y si bien ese dilema no admite una respuesta consensual y definitiva, la historia presenta, en cambio, una lección negativa: todo esfuerzo por eliminar un derecho en nombre de otro, por construir una sociedad igualitaria sin individuos libres o por afirmar la libertad individual pero sin sentido de solidaridad, transforma a la sociedad o bien en una prisión o bien en una selva.

El conflicto, en general violento (por lo menos en la percepción de las actores sociales), entre libertad individual e igualdad social — o según los términos de Luc Ferry y Alaln Renault, ${ }^{11}$ entre derechos-libertades y derechos-créditos (esto es, créditos ante el Estado), también denominados derechos materiales —, recorrió la historia política moderna y cobró su expresión clásica en la confrontación delliberalismo con el socialismo y el comunismo. Los diversos esfuerzos de creación de modelos societarios navegaron, y todavía navegan, entre aquellos que, en nombre de los derechos individuales, se niegan a aceptar que el Estado garantice una mayor igualdad, y aquellos que, en nombre de la igualdad, se disponen a delimitar, o incluso a eliminar, las libertades individuales. Pero los términos de esa síntesis cambian a medida que, como veremos, se rede finen los actores sociales y los tipos de igualdad demandada.

En la tradición socialista clásica, en particular la asociada a la obra de Marx, las críticas a las libertades civiles y políticas fueron formuladas en nombre de una realidad social encarnada por el proletariado de la Europa de mediados del siglo XIX. Para Marx, la igualdad ante la ley, era una mistificación que enmascaraba la efectiva desigualdad de las condiciones de vida. El "hombre" al que se refiere el discurso de los derechos humanos, según Marx, es el individuo egoísta, aislado y separado de la colectividad. El movimiento comunista - y también parte del movimiento socialista - nunca consiguieron separarse completamente de la idea de que los derechos individuales y el sistema jurídico moderno estaban al servicio de las clases dominantes.

En América Latina, la versión local de esa perspectiva, hasta los afios 70, incluía la visión de que el Poder Judicial (y, en general, también el Legislativo) estaba al servicio de la oligarquia y

\footnotetext{
${ }^{11}$ Luc Ferry y Alain Renault, Philosophie Politique.
} 
del imperialismo, y de que las reformas necesarias para asegurar tanto el desarrollo económico como las políticas distributivas exigían gobiernos fuertes así como la destrucción de las instituciones liberales "burguesas".

Como lo mostró Claude Lefort, ${ }^{12}$ la perspectiva marxista se sustenta en una visión del mundo que reduce la sociedad a relaciones de explotación y dominación. En ese universo no habría lugar para la política, a no ser bajo una súbita explosión revolucionaria, pues son precondiciones de la vida política la libertad de pensamiento, de expresión y de asociación, la autonomía individual y la existencia de un espacio público así como formas civilizadas de oposición. En suma, una esfera jurídica autónoma es la condición de la reinvención constante de lo social, incluso de la defensa, de la expansión y creación de nuevos derechos.

Aunque en los países latinoamericanos la experiencia de las dictaduras militares de los afios 70 y 80 y la caída del comunismo hayan motivado la conversión de los intelectuales de izquierda hacia una ideología centrada en los derechos humanos, todavía existe una amplia zona obscura en cuanto a la relación entre derechos humanos y las instituciones que deben sustentarlos, zona alimentada por la extrema desigualdad social y por la brutal diferencia en el acceso alos cuerpos de justicia, así como por la corrupción y la desmoralización de la vida política. También persiste un anticuado marxismo antiliberal, así como una asociación de la democracia liberal con la hegemonía de los Estados Unidos y la fascinación por regímenes autoritarios que desarrollan políticas sociales igualitarias y/o presentan un discurso de confrontación con la globalización económica y cultural, aunque ello envuelva la supresión de las libertades individuales, de expresión, de organización política y sindical, así como de creación cultural.

Si en nombre de la igualdad, parte de la "izquierda" estuvo dispu esta a sacrificar las libertades individuales, parte de la "derecha", atemorizada con el avance de las reivindicaciones de los sectores populares, procuró limitar, primero, el acceso al voto, después la organización sindical $\mathrm{y}$, finalmente, la formación de partidos políticos de base obrera.

Con todo, aunque los argumentos de la izquierda y la derecha puedan asociarse a visiones unilaterales, los problemas teóricos y prácticos presentados por ambas partes son legítimos: ide qué vale la libertad civil y política sin un mínimo de condiciones de acceso alos bienes de la civilización y sin oportunidades efectivas de competir en el mercado de trabajo? Por otro lado, la solidaridad no puede ser una justificación para que el Estado concentre un enorme poder discrecional y expanda su área de actuación en campos que afectan la libertad individual.

La creciente complejidad del ordenamiento jurídico desde los inicios del siglo $\mathrm{XX}$,

\footnotetext{
${ }^{12}$ Claude Lefort, L'invention démocratique, cap. 1, "Droit de L'hornne et politique".
} 
incluyendo la absorción de nuevos derechos sociales, dio lugar a una reacción liberal a partir de la dificultad del Poder Judicial por mantener su lugar específico en el sistema político. A medida que el ordenamiento jurídico pasó a ser depositario de derechos materiales, el Poder Judicial se distanció de la defensa de valores básicos y universales de la sociedad para transformarse en un actor político más. Bajo una perspectiva conservadora, Max Weber ya se lamentaba de esta "substanciación" del Derecho, retomada casi un siglo después, desde un ángulo diferente, por Habermas en su crítica a la colonización de la sociedad por el Estado ${ }^{13}$.

En este inicio de siglo XXI, en lugar del modelo de Marshall, es decir, de un conjunto de formas de ciudadanía que se van acumulando, lo que se manifiesta es un proceso bastante diferente, de implosión de derechos, una transformación de los derechos civiles y políticos a través de la inclusión de nuevos sujetos sociales (de género, ninos, minorías sexuales), junto al surgimiento de nuevas esferas de derecho (como la ecología, la reproducción, la información) y una mutación (en general declinación) de derechos sociales aparentemente consolidados, en particular, los ligados al mundo del trabajo.

El marco propuesto por Marshall, de un concepto de ciudadanía civil y política completada por la ciudadanía social, tuvo sentido en tanto esta última se refería a un conjunto de derechos que podían ser vistos, de cierta forma, como una ampliación de éstos, ya que el derecho de propiedad es un componente central de acceso a la vida civil. Efectivamente, los derechos sociales relacionados con el mundo del trabajo, constituían una manera de permitir la socialización de la propiedad, a través de lo que Robert Castels denominara el acceso a la "propiedad social"14.

Así, si retomamos la problemática inicial de los mecanismos fundamentales que operan como precondiciones de la existencia de la ciudadanía, por lo menos en la actual fase de la crisis de la "síntesis socialdemocrática" de pos-guerra, ${ }^{15}$ en que los propios derechos laborales se fragmentaron y ocupan un lugar cada vez menor en relación con una miríada de nuevos derechos, tal vez sea necesario recuperar la distinción entre los derechos fundamentales, que permiten el ejercicio de la ciudadanía, y aquellos asociados a grupos y a reivindicaciones específicas.

Ante la multiplicación de derechos, o bien se acompana el sentido común — y se pasa a definir cada uno de ellos como una nueva "dimensión" de la ciudadanía, transformándola en sinónimo de "derechos" —, o bien se les atribuye un sentido teórico y político preciso. Sin llegar a cuestionar la legitimidad de cualquier connotación que el sentido común le atribuya a la noción de ciudadanía (y el análisis de los diversos usos y formas de apropiación de ese término es un

\footnotetext{
${ }^{13}$ Ver Jürgen Habermas, The Theory of Communicative Action.

${ }^{14}$ Ver Robert Castel y Claudine Haroche, Proprieté privée, proprieté sociale, proprieté de soi.

${ }^{15}$ Ver Pierre Rosanvallon, La crise de l'état-providence.
} 
importante campo de investigación para la ciencia social), desde el punto de vista analítico podemos identificar en tomo de Ia ciudadanía dos conjuntos bastante diferentes de derechos.

El primer núcleo está constituido por los derechos civiles y políticos, que afectan de forma universal a todos los ciudadanos. En tanto afirman la igualdad de todos los individuos, esos derechos son precondiciones de la vida democrática y de la lucha por derechos específicos. El segundo núcleo se refiere a las demandas de grupos sociales específicos, generalmente derechos créditos, que muchas veces operan como precondiciones del usufructo efectivo de los derechos civiles y políticos.

Tal distinción posibilita analizar la tensión sistémica que se establece entre los mecanismos básicos que aseguran la existencia de la ciudadanía en las sociedades capitalistas liberales y los nuevos derechos que surgen y se legitiman en nombre de los derechos fundamentales. Igualmente permite estudiar la dinámica de la transformación generada a medida que el sistema jurídico absorbe nuevos derechos. En las sociedades capitalistas democráticas, limitar la ciudadania alos derechos civiles y políticos no implica negar la relevancia social y moral de otros derechos, ni olvidar que los derechos civiles y políticos sufren constantes transformaciones con el correr de la historia. La distinción entre derechos asociados a la ciudadanía y derechos específicos tiene como función teórica crear un marco de referencia que permita analizar el impacto de la demanda por nuevos derechos -generalmente referidos a grupos sociales específicossobre las condiciones básicas de reproducción del sistema jurídico-político de las sociedades modernas.

Esa perspectiva nos permitiría enfrentar un problema central de las sociedades contemporáneas: el pasaje de los "derechos" al Derecho. Este último no puede ser visto como una sim pie traducción de demandas sociales "reales" en un lenguaje jurídico formal. Para ser efectivo, ese pasaje requiere de un doble movimiento. El primero, que será discutido más adelante, de elaboración tanto política como institucional de los nuevos derechos, de forma tal que sean asumidos efectivamente por el ordenamiento jurídico y por el sistema institucional del Estado después de ser formulados por el sistema partidario y de ser integrados en una agenda política. El segundo movimiento es de integración de los nuevos derechos en el lenguaje y las categorías específicas del Derecho, lo cual implica reconocer, como veremos a continuación en el ejemplo del derecho laboral, que las categorías del derecho no son un simple reflejo de las realidades sociales, que ellas se sustentan en otro tipo de abstracción y de lenguaje discursivo, en particular, en la categoria abstracta de individuo como sujeto legal, sobre el cual se asienta la sociabilidad moderna. 


\section{Capitulo II}

\section{De los derechos laborales al derecho de las minorias}

La contradicción entre derechos-libertades y derechos-créditos recorre la historia política moderna. Durante dos siglos en Europa y un siglo en América Latina, el centro de gravedad del conflicto social en torno a los derechos-créditos fue la integración del obrero — o, en términos más generales, del mundo del trabajo - al orden jurídico y político de la sociedad moderna. Tal integración estuvo asociada a las luchas de los sindicatos, de los movimientos sociales y de los partidos políticos por el acceso de todos los ciudadanos a un conjunto mínimo de bienes; la mayoría de las veces, dicha integración se dio a través de la movilización de símbolos inclusivos, nacionales y aún nacionalistas, o, por veces, dentro de un horizonte de ideas internacionalistas. Como veremos, hoy son otros los grupos sociales, los tipos de reivindicaciones y de símbolos utilizados, distantes de las referencias al Estado nacional y de la utopía socialista, centrada en el movimiento obrero.

Nuestro foco está centrado, por tanto, en el ocaso de ese conflicto, en su forma dominante, durante los siglos XIX Y XX, entre trabajadores y empleadores. Antes de avanzar en la dirección de los procesos contemporáneos, es importante indicar cómo algunas de las tendencias que nos parecen hoy inéditas constituyen una respuesta a problemas heredados con los que, por tanto, tiene continuidad- o son tendencias parcialmente tejidas durante Ia lucha por Ia expansión de los derechos sociales ligados al mundo del trabajo.

\section{El pasaje del contrato de trabajo a los derechos sociales}

Los valores de justicia social son anteriores al discurso de la modernidad, construido en torno a la idea de derechos subjetivos, esto es, conforme a la noción según la cual cada individuo es un sujeto portador de derechos, en un mundo en el que el orden jurídico está totalmente separado de las instituciones religiosas y fundamentado en un acuerdo racional entre los miembros de una comunidad $^{16}$. A diferencia de los modernos derechos individuales, la reivindicación de los "derechos sociales" están presentes a lo largo de la historia humana. En la Biblia y en el Nuevo Testamento no faltam ejemplos de orientaciones ligadas al bienestar de los pobres. Pero si la preocupación por lo "social" no supone derechos individuales, lo contrario es igualmente verdadero, tal como se aprecia incluso en la actualidad. Que las libertades individuales y la justicia social no

\footnotetext{
${ }^{16}$ Ver Mareel Gauchet, La religion dans la démocratie.
} 
son necesariamente convergentes, es un hecho claramente ejemplificado en sociedades asiáticas como Singapur, Talwan o Corea, dominadas durante décadas por regímenes autoritarios, pero en las cuales la desigualdad social es mucho menor que en las sociedades liberales anglosajonas contemporáneas o aún hasta en la Europa continental.

La constitución de mecanismos de justicia social en un mundo de individuos, esto es, en un mundo en que el individuo es el único sujeto legítimo de derechos, relacionado con su prójimo a partir de contratos establecidos libremente, fue una tarea históricamente formidable y altamente compleja. Enfrentar el desafío de mantener la tensión entre los valores de libertad individual y de solidaridad — sin caer en las repuestas autoritarias del comunismo y del fascismo - es lo que hizo posible la humanización del capitalismo y la construcción del Estado de bienestar social.

Como lo muestra Alain Supiot ${ }^{17}$, la contradicción que tuvo que resolver el derecho moderno está referida a un contrato de trabajo en el que individuos libres e iguales aceptan relaciones de subordinación y obediencia. Dicha contradicción plante a la discusión de lo que es el trabajo: ¿un atributo de la persona o una cosa? Lo que está siendo sometido, ¿es el trabajo o el trabajador? Enfrentar tal contradicción implicó fundar y legitimar el espacio de una nueva área de derecho: el derecho laboral.

Supiot muestra cómo las soluciones jurídicas para construir el derecho laboral varían de acuerdo con las diversas tradiciones nacionales. Así, por ejemplo, en el derecho consuetudinario anglosajón, caracterizado por su énfasis en las cuestiones de procedimiento y en las soluciones contextuales, el derecho laboral se constituyó en torno a variadas situaciones y a la definición de diferentes tipos de "servicios" prestados. En la tradición francesa, enralzada en la romana, se procuraron soluciones inclusivas, a partir de una definición abstracta del trabajo y de una clara diferenciación entre individuo y cosa. El énfasis es puesto aquí en la libertad individual de las partes, incluso, en la libertad de negociar su fuerza de trabajo, lo que implica un movimiento de ruptura radical con la tradición medieval. Finalmente, el Derecho germánico, enralzado en la tradición premoderna de reconocimiento de los contratos de trabajo como lazos personales y como obligaciones de protección mutua, acepta la figura de la comunidad, más allá del individuo y del Estado. Mientras la visión centrada en el individuo tiene dificultades para reconocer en el contrato de trabajo algo más que una relación entre hombres libres, en la perspectiva comunitaria el trabajador adquiere una posición estatutaria, como miembro de la comunidad de trabajadores, en la cual el contrato de trabajo individual ocupa un lugar subordinado. Así, el foco de la relación contractual individual es trasladado hacia lIa empresa, hacia una comunidad que une a empleados y

\footnotetext{
${ }^{17}$ Alain Supiot, Critique du droit du travail.
} 
a empleadores.

La historia del derecho laboral, en particular en la tradición individualista difundida en Europa por el código napoleónico, es la historia del proceso de reconocimiento de la particularidad del contrato de trabajo y de la exigencia de una regulación específica, la cual estuvo destinada a limitar la arbitrariedad de dicho contrato al contemplar el hecho de que, aunque se trate de un contrato entre individuos libres, el mismo pone en juego no sólo el trabajo sino también el trabajador. O sea, la "cosa" trabajo no puede ser distinguida de la "persona" trabajador. El contrato de trabajo, por lo tanto, debe contemplar no sólo el objeto en sí -la prestación de un servicio cuya contra partida es una remuneraciónsino también al prestador del servicio. Como bien sabemos, esa historia está íntimamente asociada a la lucha de los movimientos sociales, de los sindicatos y partidos políticos socialistas.

Ese conflicto acarreó una tensión entre el lugar central dado al individuo como categoría fundante del derecho moderno y la integración de categorías sociales colectivas, poseedoras de un status ("trabajador"), a las cuales el liberalismo clásico procuró arrojar al basurero de la historia. El reconocimiento de categorías colectivas transformó al trabajador en una categoría jurídica, lo cual permitió, primero, la legalización de los sindicatos, vistos anteriormente como un monopolio que impedía la libre negociación individual, y finalmente, la integración de diferentes organizaciones colectivas de los trabajadores en las negociaciones de salarios y condiciones de trabajo.

Como consecuencia de esa transformación se modificó la noción de patrimonio - el conjunto indivisible de bienes y obligaciones de una persona- visto hasta entonces como una simple extensión del individuo. ¿Cómo definir el trabajo: como un objeto, un patrimonio de la propia persona, y por tanto una mercadería negociable a discreción de cada persona - cuya consecuencia potencial última sería permitir un contrato de esclavitud -, o como una categoría que remite alos derechos inherentes a la persona? Como indica Supiot "la historia del derecho del trabajo fue la historia del descubrimiento progresivo de la dimensión personal de ese bien, que condujo al primer plano, no al trabajo como bien, sino al trabajador como sujeto de derecho". ${ }^{18}$ Detrás del derecho laboral se encuentra la idea revolucionaria — que fundará posteriormente la legislación de defensa del consumidor - según la cual un contrato sólo puede ser válido cuando es realizado entre dos partes libres y en igualdad de condiciones de negociación.

La integración de esos derechos y el reconocimiento de nuevos actores, como los sindicatos, desdoblaron la persona "trabajador" en sujeto y objeto del contrato de trabajo. Eso

\footnotetext{
${ }^{18}$ Ibid, p.44.
} 
implicó aceptar que el proceso de intercambio de mercaderías (en el caso del contrato de trabajo) incluye valores no patrimoniales, en particular, el sustrato del cuerpo de la persona empleada $^{19}$. Ese proceso fue realizado sin dejar de lado la personalidad jurídica individual como base de la regulación social.

Tal revolución del derecho acarreó una profunda transformación del capitalismo, teorizado por Marx, cabe recordar, bajo la suposición de que el contrato de trabajo puede ser reducido a un intercambio puramente mercantil20. En la sociedad capitalista, sin embargo, el contrato de trabajo pasó a ser mediado por un sistema de regulación social, tendiente a uniformizar las condiciones y los límites dentro de los cuales dicho contrato sería válido y, por tanto, a delimitar las características de un acuerdo contractual mercantil entre dos partes libres. Con el derecho laboral, las relaciones sociales de producción pasaron a ser mediadas por el sistema político-jurídico, mientras que los intereses y los destinos de los asalariados se integraron a la dinámica del sistema democrático.

De esta forma se reconoció que el trabajo no puede ser disociado del trabajador, o en otros términos, se enunció que todo trabajo compromete a un trabajador (lo que, a su vez, significa el reconocimiento de su "materialidad", esto es, si es un nino o un adulto, hombre o mujer, enfermo o embarazada, etc.). Así, la primera preocupación de la legislación laboral se centró en el cuerpo del trabajador, en la necesidad de disociar el uso del trabajo del uso del cuerpo, esto es, de proteger el cuerpo del trabajador de su destrucción por el trabajo o durante el trabajo (la "medicalización" del cuerpo del trabajador estuvo inicialmente asociada a las horas de trabajo - y del sueno- y también alos accidentes de trabajo, que eran epidémicos en la Europa del siglo XIX).

La regulación política y la legislación del trabajo en parte enfrentaron el problema responsabilizando al empresario por las condiciones de trabajo, empleando fundamentalmente el mecanismo del "seguro social" universal. Tal mecanismo, después extendido a la jubilación y alos desempleados, fue la resultante, como muestra François Ewald ${ }^{21}$, del uso de los conocimientos de estadística, en particular, de las técnicas comerciales aplicadas a los seguros, para solucionar problemas sociales. Así, fue posible la socialización de los costos de los accidentes de trabajo y, posteriormente, de la vejez y de subsistencia del desempleado. El derecho al trabajo trajo aparejado, como vimos, una complejización de la idea del contrato, aunque también significó, como muestra Ewald, un cambio radical en la noción de responsabilidad. Mientras en el código civil napoleónico la noción de responsabilidad estaba originariamente asociada a la idea de "falta" y de responsabilidad subjetiva, en el caso del contrato de trabajo el accidente deja de estar vinculado a

\footnotetext{
${ }^{19}$ Ver Ibid, p.66.

${ }^{20}$ Ver Karl Marx, O capital.

${ }^{21}$ François Ewald, Histoire de l'état providence.
} 
una responsabilidad personal del trabajador y pasa a ser considerado responsabilidad "objetiva" o aún responsabilidad del empresario, en la medida en que se reconoce que el trabajador, durante el proceso de trabajo, alienó su libertado

El proceso de afirmación de una identidad jurídica es concomitante a la afirmación identitaria del trabajador como grupo social específico, o sea, de la invención de la categoría moderna de trabajador. Pero lo contrario también es verdadero: el debilitamiento identitario está acompaliado por una transformaciãn de los derechos. Pues si el derecho del trabajo creó la abstracción jurídica del trabajo, también admitió las distinciones profesionales, que, por su parte, reforzarán diversas estrategias, de empleadores y empleados, procurando o bien la división de la categoría, o bien la obtención de ventajas diferenciales para cada grupo. Así, trabajadores manuales y empleados, funcionarios públicos y del sector privado, condiciones de empleos insalubres y las particularidades de la maternidad, por sólo citar algunos ejemplos, vinieron a asociar las diferencias a derechos, fragmentando el mundo del trabajo y fortaleciendo el corporativismo de las categorías profesionales. Posteriormente, se integraron a la legislacián del trabajo categorías de asalariados ligados alos cuadros superiores de la jerarquía de las empresas, y en las últimas décadas, a partir de las nuevas formas de gestián y ilexibilización del empleo, fueron reguladas las más variadas formas de trabajo precario y de auto-empleo.

El derecho laboral engendró un movimiento que terminá por producir una nueva percepción sobre los derechos sociales. Se reconoció que por encima de los derechos específicos asociados al contexto del trabajo se encuentra una persona humana, o más especificamente, un conciudadano, con el derecho a reproducirse, independientemente de tener trabajo o no -incluyendo a aquellos que por alguna razón (por ejemplo, enfermedad o edad), no consiguieran obtener una renta mínima vital. Lo cual derivó, finalmente, en la extensión de los derechos originados en el mundo del trabajo (incluyendo una renta mínima, jubilación y servieios médicos) a todos los ciudadanos, configurando así el estado de bienestar social.

Al crearse un mínimo común de derechos a la seguridad y al bienestar, se afirmaron las tendencias a la fragmentación de los derechos de los trabajadores a partir de categorías y subcategorías específicas. Los empleadores, dada la existeneia de un sistema de proteceión social universal, procuraron, en sus empresas, ilexibilizar e individualizar al máximo los contratos de trabajo y la negoeiación salarial, recuperando parte del espaeio perdido con la expansión del poder sindical.

En ese nuevo contexto, en tanto ios trabajadores más calificados perseguirán estrategias cada vez más individualizadas y otros grupos -en particular los funcionarios estatales- defenderán derechos corporativos, los trabajadores descalificados perderán su capacidad de negociación, la 
dignidad y el reconocimiento social. Retomará así la sensación de que el trabajo es una mercancía desprovista de cualidades subjetivas. El resultado será un creciente debilitamiento de los sindicatos y de la importancia de las negociaciones colectivas así como el desmantelamiento, en última instancia, de las identidades asociadas al mundo del trabajo.

El derecho laboral -y ahí radica su importancia- revolucionó las categorías fundamentales del mundo jurídico, tal como fuera postulado por la democracia liberal, ${ }^{22}$ abriendo las compuertas para una posterior implosión de derechos.

En primer lugar, el derecho laboral redefinió la distinción entre desigualdad y jerarquía. Aunque la jerarquía - es decir, existencia de posiciones diferentes en la cadena de mando — sea ciertamente permitida, incluyendo el reconocimiento de un amplio espacio de indeterminación en el contrato de trabajo, a ser llenado circunstancialmente, ella no podrá dar lugar a un poder que autorice el tratamiento desigual, esto es, la ley no permitirá la discriminación entre trabajadores por criterios externos al mundo del trabajo. Así, el contrato de trabajo instituye la jerarquía entre iguales -relaciones de subordinación y de limitación del ejercicio de la voluntad individual-, pero excluye la discriminación.

En segundó lugar, el derecho laboral generó una fraternidad objetiva asumida por el Estado — por tanto, una responsabilidad solidaria fuera de la esfera privada, en particular, de la familia creando una nueva figura colectiva de la ciudadanía, expresada en la forma de derechos sociales a una seguridad mínima. Con todo, esa figura fraternal será constituida como una estructura racional, a partir del reconocimiento de la interdependencia del sistema social, y no como producto de individuos subjetivamente solidarios. Aún la participación sindical o a nivel de huelgas será, en los códigos liberales del trabajo, un derecho y no una obligación. Esa visión fue cuestionada por el derecho de origen fascista -tendi ente a recrear instancias colectivas intermediarias obligatorias entre el individuo y el Estado- y despreciada por la tradición socialista revolucionaria, que via en esos derechos una nueva forma de dominación y de mistificación de la explotación a la que estaba sometida la clase trabajadora.

El derecho laboral fue un esfuerzo por integrar las dimensiones colectivas y solidarias de la vida social en las categorías jurídicas de la modernidad, fundada en el valor de los derechos individuales universales. Se trató de un proceso altamente complejo, pues, como indica Supiot ${ }^{23}$, el valor jurídico de la igualdad no puede ser confundido con la ideología del igualitarismo social, confusión facilitada por la utilización, en ambos casos, de la noción de igualdad. La introducción de

\footnotetext{
${ }^{22}$ Lo cual incluye la tradición jurídica estadounidense, en la que la Suprema Corte de Justicia, durante anos, intentá oponerse a la legislacián social introducida por Franklin Roosevelt.

${ }^{23}$ Supiot, op.cit, p.135.
} 
valores de igualdad material — implicitamente reconocidos por el derecho laboral y llamados a exigir la intervención reguladora del Estado - tuvo como objetivo restablecer la plena vigencia de la igualdad jurídica, sin dejar de reconocer la tensión entre las dimensiones sociales y jurídicas.

El derecho puede pecar por exceso o por timidez: en el primer caso, al juridicionalizar categorías sociales particulares (como, por ejemplo, los desempleados), provocando la consolidación del status y la estigmatización de ciertos grupos sociales que se pretende promover; en el segundo caso, al permitir la profundización de las desigualdades sociales, afectando en la práctica el funcionamiento efectivo de las categorías jurídicas de igualdad.

El sentido de lo colectivo, instaurado por los derechos sociales, sirvió para crear entre los trabajadores una autonomía que ellos no poseían como individuos frente al empleador, sin por ello negar su condición de personas jurídicas individuales y autónomas. El orden público instaurará así las "libertades individuales de actuar colectivamente". ${ }^{24}$ El objetivo último del derecho laboral es el mismo del derecho civil: "civilizar" las relaciones sociales al interior de la empresa, substituyendo las relaciones de fuerza - tendi entes a poner en riesgo la propia seguridad de los individuos — por relaciones de derecho, promoviendo la transformación del trabajo y de la empresa en objetos de derecho.

La importancia del derecho al trabajo consiste en que reconoce la tensíón entre los "derechos-libertades" y los "derechos-créditos", entre las dimensiones sociológicas y jurídicas de las demandas sociales por derechos, sin confundir las especificidades de las categorías de cada una de esas dimensiones. Como indica Supiot, la racionalidad jurídica no pretende reflejar ni resolver las diversas desigualdades concretas al interior de cada sociedad, sino suministrar los instrumentos jurídicos para alcanzar una resolución pacífica $\mathrm{y}$, en lo posible justa, de los conflictos.

El mundo de las desigualdades materiales se vincula a diversas relaciones de fuerza entre los varios actores sociales, que se encuentran en permanente mutación y sobre las cuales el derecho tiene una limitada capacidad de actuar. Suponer que el derecho pueda dar una respuesta a cada situación concreta de conflicto social implicaría destruir las regIas universales que permiten a cada sujeto poseer su carácter de individuo autónomo. De lo contrario, el derecho se disolvería en la sociedad ("representada" por el Estado en el caso de las sociedades autoritarias), lo que derivaría en el reino de lo arbitrario o en la destrucción de las bases de autonomía del individuo y de las libertades fundamentales. Como indica Supiot, "la legalidad supone un corte entre las reglas de derecho y otras reglas sociales",25.

\footnotetext{
${ }^{24}$ Ibid, p. 140.

${ }^{25}$ Ibid, p. 215.
} 
Debemos siempre recordar que el sujeto jurídico es una construcción abstracta (en la práctica existen personas concretas, cada una con sus características específicas), es una ficción que se reconoce como tal, pero que habilita al conjunto de los individuos a participar de las reglas del derecho, las cuales atribuyen "a cada individuo un lugar, una identidad, esto es, la cualidad de sujeto de derecho"26. La promoción de derechos debe orientarse en el sentido de que representen o modifiquen adecuadamente los marcos jurídicos e institucionales existentes; de lo contrario, se corre el riesgo de caer en ideologías ignorantes de las precondiciones efectivas en que los nuevos derechos de hecho pueden ser operacionalizados.

\section{Desigualdad social, mercado y Estado}

El orden social establecido por el Estado de bienestar reorganizó las bases de la estratificación social. En los países avanzados (aunque también en varios países en desarrollo) entre un tercio y la mitad del Producto Bruto Interno es apropiado por el Estado y distribuido a través de servicios públicos. Al tomarse la distribución de rentas como medida de la calidad de vida debe considerarse tanto la renta individual (que sigue siendo empleada como criterio de estratificación económica) como el costo de los bienes públicos alos cuales los ciudadanos tienen acceso (por ejemplo, educación, salud, seguridad, justicia, transporte subsidiado).

Tenemos, pues, una doble estratificación: una determinada por la renta individual y otra por el usufructo de bienes públicos. En principio, la estratificación por la renta individual tiende a ser mucho más desigual que la producida por la distribución desigual de bienes públicos, la cual aspira en términos ideales a ser no sólo igualitaria sino también compensadora de la estratificación determinada por el mercado. El impacto de los bienes públicos en la compensación de la desigualdad social no siempre es efectivo, y algunos de esos bienes, en especial, la educación, favorecen particularmente a las clases medias. En Brasil, por ejemplo, los grupos más pobres de la población son, en general, los menos beneficiados por los servicios públicos, y en ciertos casos, como en el de los policias corruptos o brutales, su presencia puede llegar a ser un gravamen para la población de los barrios populares.

Aunque hoy existe un movimiento tendi ente a separar las políticas sociales de las políticas de regulación del mercado, los derechos sociales y los servicios públicos siempre afectaron el mercado de trabajo y la organización de la producción. ¿En qué medida es posible desarrollar de forma efectiva políticas sociales orientadas por un principio de justicia distributiva y al mismo tiempo desregular el mercado de trabajo en la dirección de un "contractualismo"? Si, por un lado, la

\footnotetext{
${ }^{26}$ Ibid, p. 220 .
} 
incapacidad creciente de los sindicatos de mantener y generar derechos sociales contiene potencialmente un factor de liberalización de las políticas sociales anteriormente asociadas alos intereses corporativos de grupos de asalariados con mayor capacidad de negociación, por otro lado, es dudoso que, sin presiones sociales, el Estado se oriente por políticas "éticas" de expansión de servicios públicos con objetivos igualitarios.

En el siglo XX, por lo menos en los países desarrollados, la solidaridad interpersonal fue sustituida en buena medida (aunque nunca del todo, pues la familia, la amistad y la filantropía continuaron jugando un papel solidario importante) por técnicas sociales fundadas en una responsabilidad pública y jurídicamente regulada. La transferencia de responsabilidades significó una transformación del ideal liberal, el cual, aún reconociendo la importancia de la solidaridad, consideraba que és ta era una responsabilidad moral de los miembros de la "sociedad civil", extrafla por tanto a la tarea de gobernar.

El derecho laboral se originó en la lucha de los trabajadores y en los diagnósticos de los propios organismos del Estado y de los intelectuales sobre las razones de la pobreza generada por el nuevo mundo industrial, diagnósticos que indicaban la necesidad de una intervención pública. Así, se desnaturalizó la cuestión de la desigualdad social, esto es, la misma ya no podía ser atribuida a un designio divino ni explicada como el producto de un orden natural del mundo. La pobreza pasó a ser diagnosticada como una disfunción del sistema, susceptible de ser corregida a través de una ingeniería (o de la revolución) social.

La principal técnica para resolver la cuestión social fue la obligatoriedad del seguro social. Como indicamos, la aplicación de la tecnología estadística del control del riesgo es el fundamento de la moderna seguridad social. El camino de aplicación de la tecnología del seguro universal obligatorio estuvo asociado a dos fórmulas aplicadas de modo diferente en cada país, pero siempre combinando cotizaciones de los trabajadores y patrones y/o impuestos directos.

A través de un largo camino -en el cualla gran crisis de 1929, las dos guerras mundiales y la expansión comunista fueron factores fundamentales- se consolidó una nueva esfera de acción estatal: la esfera social. El Estado capitalista pasó a ser un Estado de bienestar (welfare state) y creó lo que Roberto Castels denomina la "propiedad social"27, una serie de bienes colectivos considerados como un substituto funcional de la propiedad individual, tendientes a asegurarles alos individuos el acceso a los soportes necesarios para que participen del mercado de trabajo, de las formas de consumo y de la sociabilidad modernas. Por sus propios orígenes, asociado a la voluntad de integrar las clases populares alos sentimientos patrióticos, el Estado de bienestar social fue un

\footnotetext{
${ }^{27}$ Robert Castels e Claudine Haroche, Proprieté privée, proprieté sociale e proprieté se soi.
} 
proyecto de integración de la sociedad en torno al Estado Nacional.

A partir de los afios 70, el Estado de bienestar entró en crisis, aunque es importante sefialar que continúa siendo hasta hoy el fundamento de la integración social de las sociedades capitalistas avanzadas. Inicialmente, la crisis fue diagnostica da como una crisis fiscal, ligada a transformaciones demográficas (al aumento de la longevidad y a la disminución de la tasa de natalidad, con la consecuente modificación de la pirámide etaria, de forma que el sistema providencial, según el cual la generación más joven asume los costos de la más vieja, quedó inviabilizado), además del crecimiento exponencial de los gastos en salud pública y del aumento del nivel de desempleo.

La crisis del Estado de bienestar es producto de un largo proceso por el cuallos "derechos sociales", originados en torno a la figura del trabajador, pasaron a ser generalizados y, en buena medida, desconectados del sistema de seguros obligatorios que los financiaba. A medida que nuevos sectores fueron acoplándose al Estado de bienestar, los costos fueron transferidos a los grupos "pagadores", esto es, a trabajadores y patrones, o al Estado, que a su vez se financiaba a través de impuestos o de políticas inflacionarias. El nuevo contexto creó las condiciones para las llamadas políticas neoliberales, apoyadas por amplios segmentos sociales que se sentían perjudicados con la dinámica de financiamiento de los crecientes costos de mantenimiento del sistema o afectados por la inflación ${ }^{28}$.

Una enorme bibliografia vino a sefialar que parte importante de los recursos que debían asignarse alos sectores más necesitados permanecía en las clases medias y que, en lugar de ser un instrumento de integración, las políticas sociales reforzaban la estigmatización y la reproducción de los grupos exclui dos. El Estado de bienestar sufrió, por tanto, una doble erosión: en lo alto, en razón de los problemas de gobernabilidad, y en la base, debido al distanciamiento creciente de las clases medias de las ideologías solidarias. Hasta intelectuales de izquierda pasaron a ver en as crecientes sistemas de control del Estado una intromisión indebida y autoritaria en la vida privada ${ }^{29}$.

El esfuerzo por manejar el presupuesto público con vistas a disminuir el déficit fiscal, a partir de las afias 70, o con el fin de adecuarse a las exigencias de una inserción competitiva en el mercado internacional, a partir de las afias 80, implicó una serie de reformas del Estado, privatizaciones y cambias en la legislación social, al tiempo que produjo una enorme bibliografía en tomo al tema de la gobernabilidad y de la buena gobernanza pública, concepto que vino a indicar la necesidad de contar con instrumentos apropiados para asegurar la transparencia, medir y evaluar la eficiencia en la alocación de las recursos públicos. Pese a las reformas del Estado de bienestar -

\footnotetext{
${ }^{28}$ Sobre el impacto social de la inflación en Brasil ver Bernardo Sorj, A nova sociedade brasileira, cap. 3. 29 Ver Pierre Rosanvallon, La nouvelle question sociale.
} 
todavía en curso en Europa y en la mayoría de las países de América Latina - en las que algunos derechos laborales y de previsión social fueron modificados o eliminados, las gastos de las Estados capitalistas en materia social se mantienen constantes, o ineluso han aumentado, así como la participación del presupuesto estatal en el total del producto interno bruto ${ }^{30}$. Por lo tanto, no debe olvidarse, que el Estado de bienestar continúa siendo el fundamento de la solidaridad social y de las expectativas de derechos básicos en las Estados capitalistas avanzados. La cuestión central que se impone en la actualidad está por tanto referida a la capacidad del Estado para compensar las desigualdades crecientes generadas por el mercado y limitar las efectos nocivos de la desregulación de las relaciones de trabajo producida por la contra-revolución contractualista sobre la salud física y mental de los asalariados.

Si el desmonte de las estructuras corporativistas elimina, por un lado, ciertos privilegias claramente insustentables de acuerdo al clima reinante en estas nuevos tiempos, también corroe, por otro lado, la ética profesional asociada a ciertas actividades que exigen una dedicación a valores colectivos, como en el caso de las servicios públicos.

Es más; más aliá de las problemas administrativos y fiscales, la crisis del Estado de bienestar social refleja una transformación social de fondo, llamada a cuestionar su legitimidad, en razón del distanciamiento creciente entre, de un lado, la base social de las políticas públicas aneladas en las relaciones de producción y en la ideología igualitaria asociada a la clase obrera y, de otro, las nuevas tendencias de la sociabilidad moderna. Como sostiene Robert Castels, a partir de mediados de los afios 70 se produjo una "precarización de las pertenencias colectivas, o incluso una fragilización de las categorías homogéneas que constituían la sociedad salarial" ${ }^{31}$.

Como vimos, el mundo del trabajo se fue fragmentando incluso como expresión del propio suceso de las negociaciones de los diferentes grupos de asalariados. Pero, a partir de los afios 70, se aceleró la transformación interna de la clase trabajadora bajo el impacto de múltiples factores. La disminución creciente del peso del sector industrial y el crecimiento del sector de servicios llevaron a una retracción, en términos tanto relativos como absolutos, del número de trabajadores manuales — que eran los principales portadores de la tradición sindical y de la ideología igualitaria — en el conjunto de los asalariados. A su vez, las nuevas técnicas de administración de empresas, la terciarización, la flexibilización y la disminución del contingente de mano de obra empleada afectaron aún más los cimientos de los sindicatos y de las estrategias ocupacionales asociadas a la expectativa de estabilidad del empleo. Finalmente, la onda ideológica neoliberal y el fin del

\footnotetext{
${ }^{30} \mathrm{Si}$ bien en la mayorla de los países parte cada vez mayor del financiamiento del gasto público fue transferido de los impuestos directos (sobre la renta) para impuestos indirectos (sobre el consumo), socialmente regresivos.

${ }^{31}$ Robert Castel, op. cit., p. 108.
} 
comunismo debilitaron todavía más los actores comprometidos en la lucha por una sociedad más igualitaria.

\section{De la dominación anónima a la fragmentación de los derechos}

La "crisis de la clase obrera" -y de las utopías sociales a ella ligadas- es al mismo tiempo causa y efecto del proceso de creciente individuación de los valores y de las relaciones sociales que atraviesa la sociedad moderna. Tal proceso desembocó en una realidad que algunos sociólogos consideran como una nueva fase de la modernidad (denominada por algunos "pos-modernidad" y por otros "alta modernidad"), ${ }^{32}$ cuya figura central es el individuo sin fundamento en creencias trascendentales ni tradición, condenado a una acción reflexiva permanente, esto es, a un mundo subjetivo constantemente construido y reconstruido.

El individuo contemporáneo no dispondría de un sistema rígido de identificaciones colectivas o ideológicas y estaría fragmentado en múltiples y mutantes redes y grupos de referencia. A diferencia del período moderno anterior, en el que todavía funcionaba un sistema de valores relativamente sólido en torno a instituciones tales como el matrimonio, la profesión, la educación, el partido y las ideologías, capaces de ofrecer, por lo menos en líneas generales, un sentido secular de la vida (en torno a valores como el trabajo, la patria, el progreso, la historia, el socialismo), el individuo moderno se habría transformado en un universo auto-referido, lleno de agujeros negros y de galaxias inconexas, envuelto en una intensa sensación de incertidumbre respecto a su lugar en el mundo y a su futuro.

El proceso actual de desinstitucionalización del individuo, sea hombre, mujer o nifio, trajo aparejado el debilitamiento de los mecanismos y los lazos que relacionaban al individuo con la sociedad y con el sistema cultural ${ }^{33}$. Los valores sobre los cuales se construyeron la escuela, el mundo del trabajo yel Estado entraron, si no en colapso, por lo menos en claro retroceso. Las nuevas identidades se constituyen hoy en torno al suceso monetario y al consumo asociado a estilos de vida cada vez más personalizados ${ }^{34}$.

Períodos de transformación histórica producen un "dislocamiento" entre la subjetividad de los afios formativos y los valores y exigencias de los nuevos tiempos, entre los individuos y la sociedad. Ese dislocamiento es vivido como una crisis personal y es fuente además de

\footnotetext{
${ }^{32}$ Ver entre otros Anthony Giddens y Scott Lash, Reflexive Modernization.

33 Ver Danilo Martuccelli, Dominations ordinales.

${ }^{34}$ Sobre la sociologia del consumo ver, entre otros, Daniel Miller (org.), Acknowledging Consumption; Yiannis Gabriel y Tim Lang, The Unmanageable Consumer; Don Slater, Consumer, Culture \& Posmodernism; Pekka Sulkunen John Holmwood, Hilary Radnery Gerhard Schulze (orgs.), Constructing the New Consumer Society; Jean Baudrillard, Le systéme des objets; Mary Douglas y Baron Isherwood, The World of Goods; Arjun Appadural, The Social Life of Things; y Zygmunt Bauman, Life in Fragments: Intimations of Posmodernity; El malestar de la posmodernidad.
} 
resentimiento, de frustración, de angustia y de depresión. A partir de una cierta edad, es cada vez más difícil "identificarse" con el "mundo exterior", lo que genera una profunda crisis existencial y un desencanto con la vida. Esta situación, común a toda transformación histórica, adquirió un carácter crónico e intermitente en la sociedad capitalista contemporánea.

Viviendo simultáneamente en el espacio físico, donde está situado, y en el espacio global, al cual está conectado, asociado a una temporalidad instantánea que destruye el sentido de la historia, sin tener a quién responsabilizar por su sufrimiento sino a sí mismo, el individuo reflexivo descubre que su subjetividad, en vez de espado de libertad, representa una fuente de angustia, a la que deben aplicársele constantemente técnicas de autoayuda, cuando no productos químicos, a fin de mantener la motivación necesaria para que el individuo sea un empresario de sí mismo y soportar el constante cambio e incertidumbre del mundo actual.

El individuo estaría condenado a vivir el sentimiento de un permanente distanciamiento del sentido inmediato del mundo social; a habitar un mundo fluido y en constante cambio, para el cual no está "preparado" (lo que crea un nuevo nicho de "educación continua"). El individuo se veria forzado a justificar cada uno de sus actos a partir de varias racionalidades y valores posibles; a negociar cada acción en el mundo afectivo; a sentirse fragmentado en múltiples deseos que no encuentran más valores estructurantes. En suma, estaría condenado a vivir, como en el emblemático título del libro de Ehrenberg "el cansancio de ser sí mismo"35. El individuo no sufriría más la presión del super-yo, y sus energías estarían dedicadas a administrar sus deseos, ahora abiertamente asumidos, pero imposibles en su mayoría de ser realizados; estaría condenado a convivir con sus múltiples egos y posibilidades de rescribir su historia de vida, transformando cada acto de sociabilidad en una negociación con otro o consigo mismo, produciendo una cultura en la que los dramas de la subjetividad sustituyen los dramas del espacio público o, parafraseando el título de otro libro, produciendo una cultura narcisista del "ego mínimo"36, centrada en aspiraciones privadas y en la construcción permanente, mas nunca acabada, de una auto-imagen ${ }^{37}$.

Responsabilizado por su destino, ya que tendría la libertad de rehacer su historia de vida a cada momento, el individuo sería también responsable de sus fracasos y problemas: por no haberse esforzado lo suficiente para tener un buen empleo, por no haberse alimentado adecuadamente y, por ende, por haber adquirido problemas de salud, o por no haber hecho bastante ejercicio y, por ello, haber envejecido. El individuo contemporáneo continúa sintiéndose oprimido y dominado, pero esa dominación es anónima, no tiene sujeto ni dirección cierta. Mientras en las antiguas luchas obreras

\footnotetext{
${ }^{35}$ Alain Ehrenberg, La fatigue d'être soi.

36 Christopher Lasch, The Minimal Self.

${ }^{37}$ Ver Marcel Gauchet, " Essal de psychologie contemporaine".
} 
el enemigo tenía un rostro definido, el patrón, y el origen de la dominación era claramente identificada, el capitalismo, el individuo reflexivo no consigue definir a quién culpar de sus males, lo que produce el síndrome cada vez más común de depresión y de sentimiento de fracaso, pues la persona se juzga la única responsable por sus desventuras.

Paradójicamente, la nueva modernidad estaria generando simultáneamente un individuo resignado - demasiado ocupado en administrar sus problemas como para dedicarse a cuestiones colectivas -, y un individuo más igualitario, ya que, destruidas las viejas fronteras y subculturas que separaban a las personas, tales como status social, clases sociales, naciones, ideologias, no quedaria más que la común humanidad, que el drama de la condición humana, en la cual todos los individuos pueden reflejarse e identificarse. ${ }^{38}$

El distanciamiento entre subjetividad y estructura social ha dado lugar a una esquizofrenia en la teoria sociológica. O bien se procura reconstruir la dinámica social a partir de una teorización cuya referencia central es el individuo racional y/o reflexivo y sus dramas de inserción social perdiendo de vista las "estructuras" sociales, esto es, el sistema organizado del poder económico, político y cultural —, o bien se elabora una explicación sistémica del funcionamiento de la sociedad (concepto que, de hecho, se abandona en el primer tipo de interpretación), pero distante de la subjetividad y de la autorepresentación de los individuos.

La supervalorización del individuo y del papel liberador del conocimiento, que atraviesa la cultura moderna y que fuera reforzada por el psicoanálisis y por las diversas terapias de autoayuda, encuentra su expresión, en la teoria sociológica, en la escuela de la elección racional, y más recientemente, del individualismo reflexivo. La representación que cierta sociologia hace de la condición del individuo moderno - un ser reflexivo reinventando constantemente su futuro, o un risk taker (un apostador), en las palabras de Giddens - es una idealización cuestionable y caricatural de la vida contemporánea. El individuo moderno más bien se aproxima a otra imagen, igualmente caricatural, de alguien preso en una celda, donde imagina periódicamente nuevas "narrativas de vida", de modo de mantener la ilusión de que está al timón de su biografia.

El idealismo implícito en la supervalorización de la subjetividad, de la capacidad de aprendizaje y del papel del conocimiento en la transformación de si mismo fue recientemente criticada por Danilo Martuccelli ${ }^{39}$ Para este autor el individuo no se sustenta "a partir de adentro", sino desde "soportes" externos estabiliza dores de subjetividad (desde la religión a la familia, desde los amigos al dinero). Si la hipótesis de Martuccelli fuera correcta, como creemos

\footnotetext{
${ }^{38}$ George Simmel, en particular, notá los efectos profundamente igualitarios de la modernizacián del mundo. Ver Philosophy of Money.

${ }^{39}$ Danilo Matuccelli, Grammaires de l'individu.
} 
fundamentalmente que lo es, la investigación sociológica debería analizar el proceso complejo por el cual el conocimiento y la reflexión pueden ser un instrumento de autotransformación, pero solamente en la medida en que se constituyan en un eslabón efectivo de transformación del sistema de soportes.

\section{El nuevo individualismo e identidades colectivas}

El nuevo individualismo subjetivamente "desprotegido" y sometido a dominación anónima no deja de perseguir nuevas formas de pertenencia ni de reivindicar nuevas formas de protección, de solidaridad y de reconocimiento social. Para ciertos autores, ${ }^{40}$ se trata de una radicalización de la democracia. Sin embargo, no nos parece que el análisis de los procesos sociales concretos justifique este optimismo. Más bien creemos, con Mareel Gauchet, ${ }^{41}$ que el individuo pos-moderno tiene una enorme dificultad para integrar la dimensión pública o societaria. En esta nueva realidad social, la lucha por la igualdad es substitui da por la lucha por la diferencia; los individuos ya no intentan construir una utopía socialmente inclusiva y la desigualdad sólo es relevante en relación al propio grupo más que para el conjunto de la sociedad. Incluso, la propia idea de una utopía secular unificadora de la sociedad perdió actualidad, pues ella supone una confianza en verdades y/o valores universales así como un punto de llegada en un futuro común, que ya no es buscado.

La individualización destruye afiliaciones incondicionales y fidelidades a ideologías totalizantes. Los acuerdos sobre temas específicos (issues, en inglés) ya no remiten a visiones abarcativas de los más diversos problemas de la sociedad. Cada individuo se reserva el derecho de adoptar una posición (o de cambiarla) en relación a cada tema particular, y no acepta que cada posición sea reducida a un marco único de interpretación. Aquellos que procuran marcos fundados en una autoridad externa, provistos de explicaciones y respuestas predeterminadas, emigran para visiones religiosas integristas. En sus versiones más moderadas, la pérdida de referencias fijas, el estrés o el sentimiento de falta de valores y sentidos trascendentales han llevado a una demanda creciente de "productos místicos", que van desde prácticas "light" de yoga o otras disciplinas orientales al redescubrimiento de la propia tradición religiosa.

La individualización y el igualitarismo producen una desconfianza creciente frente a las grandes burocracias, cuya opacidad e impersonalidad chocan con los valores de transparencia y de valorización de las necesidades de cada individualidad. Las principales víctimas de ese estado de espíritu son el Estado y los partidos políticos, aunque las grandes empresas son blanco también de la desconfianza pública.

\footnotetext{
${ }^{40}$ En particular Ulrich Beck, What is Globalization? Marcei Gauchet, Op. Cit.

${ }^{41}$ Marcel Gauchet, Op. Cit.
} 
En el mundo contemporáneo, el pasaje de lo individual a lo social puede apreciarse a través de dos construcciones aparentemente contradictorias, pero representativas de la nueva condición del individuo moderno. Para unos, la referencia central es el discurso de los derechos humanos, que, por su carácter altamente abstracto y general ofrece un substrato en torno al cual es posible anelar y comunicar las reivindicaciones particulares. ${ }^{42}$ Para otros, una vez perdida la visión societaria organizada en torno al Estado y al sistema político, se trata de procurar en las religiones el material para la construcción de las identidades colectivas, fuera de las incertidumbres de la sociedad mundana y del la historia.

El nuevo universo de identidades colectivas deja de basarse en vínculos de identificación socio-económica y en procesos históricos, hoy ciertamente frágiles y en permanente mutación. Dichas identidades procuran una solidez que las ampare de las transformaciones sociales y del propio individualismo; ellas se organizan o bien en torno a grupos de afinidad por identificación inmediata, relacionados con problemas específicos (vida del barrio, escuela), o bien - y ese es realmente un fenómeno nuevo - en torno a entidades (vividas como) naturales o trascendentaleso $^{43}$. Así, género, opción sexual, características físicas, grupos étnicos, religiones, regionalismos y la propia naturaleza son valores en torno alos cuales los nuevos actores colectivos elaboran hoy sus identidades ${ }^{44}$.

Las nuevas identidades funcionan como filtros capaces de delimitar los efectos relativizantes y las incertidumbres del individualismo reflexivo; ofrecen un menú de lo que es cierto o falso, además de la posibilidad de identificar un enemigo externo sobre quien descargar por lo menos parte de Ilas responsabilidades por el destino personal. Pero esas identidades no están al abrigo del individualismo contemporáneo, particularmente en el caso de las elites de esos nuevos actores sociales, para las cuales esas identidades son también estrategias individuales para negociar, en el sistema político, posiciones de poder y recursos para consolidar su ascenso social.

A pesar de las diferencias registradas entre las nuevas identidades, ellas comparten por lo menos varios de los siguientes trazos, que las distinguen profundamente del mundo del trabajo y las oponen, en cierta forma, a las reivindicaciones de este último.

\footnotetext{
42 Sobre el papel del discurso de los derechos humanos, ver Marcel Gauchet,"Quand les droits de l'homme deviennent une politique".

${ }^{43}$ El nazismo y el racismo moderno fueron precursores en esa forma de construcción de identidad, como un modo reaccionario de enfrentar la modernidad y los derechos humanos.

44 Michael J. Piore llama la atención respecto al hecho de que para la sociedad norteamerícana, con su individualismo y su dificultad para convivir con la ambigüedad, seria difícil creat identidades colectivas a no ser através de características innatas o naturalizadas (raza, sexo, trazos físicos etc.). El análisis de Piore, que no incluye la religión o el ecologismo, se aplica hoy, con las debidas adaptaciones, a todas las sociedades modernas. Ver Beyond Individualism.
} 
1) Los grupos se presentan como víctimas del sistema, o descendi entes de las visitas, razón por la cual deben ser indemnizados, aunque los responsables por el sufrimiento (p.e., esclavitud, persecuciones, expulsión de sus tierras) sean dificilmente identificables actualmente. La victimización y las compensaciones se refieren no sólo al momento actual sino a historias pasadas de opresión ${ }^{45}$.

2) Los grupos no procuran la similitud. Afirman la diferencia y el particularismo, son antiuniversalistas o ven en el universalismo un mecanismo de dominación. Esa crítica se sitúa en una relación compleja con el discurso de los derechos humanos, que pasa a ser redefinido como aceptación del derecho a la diferencia, derecho que incrementa las antinomias internas de los derechos humanos y de los ordenamientos jurídicos organizados en torno a comunidades culturales nacionales.

3) Dado que las nuevas identidades colectivas son construi das sobre la base de características "trascendentales", permanentes, se trata muchas veces de obtener una discriminación permanente, en lugar de una igualación de condiciones. En paralelo con las políticas de acción afirmativa, orientadas a igualar las oportunidades de vida, las elites de los nuevos grupos identitarios proponen políticas de discriminación positiva en el sentido de consolidar y fortalecer las identidades y subculturas particulares.

4) Las nuevas identidades colectivas enfatizan las dimensiones simbólicas de la dominación y de la opresión, aún cuando planteen reivindicaciones de orden económico. Ellas no se organizan a partir del contexto económico o productivo, por lo que no poseen parámetros de referencia objetiva sobre la "parte que les corresponde" en el mundo de la economía ${ }^{46}$.

5) Su constitución social es interclasista, aunque en la práctica dichas identidades puedan formarse mayoritariamente por un único estrato social.

6) Las nuevas identidades se definen fuera de los parámetros clásicos de derecha/izquierda y, aunque puedan estar atravesadas por las lealtades ideológicas de sus miembros, son fundamentalmente transversales en relación al sistema partidario.

Como indicamos al inicio de este libro, la ciudadanía moderna constituyó simultáneamente la noción de individuos libres e iguales y la idea de comunidad nacional. La creciente fragmentación simbólica - causada por la invasión del espacio público por dimensiones

\footnotetext{
${ }^{45}$ A este respecto, Michael Walzer comenta: "En la política cultural es una ventaja ser ofendido. Toda ofensa, todo acto de discriminación o de trato irrespetuoso, toda palabra maliciosa o de envidia confiere un derecho político, una indemnización o por lo menos un reconocimiento (de la ofensa)". Cf. "Mu/ticu/turalism and the Politics of the Interest".

${ }^{46}$ Para Michael J. Piore, "...como los grupos son definidos independientemente de la estructura económica, no existe ningún camino directo para que sus miembros comprendan cómo los recursos económicos delimitan la atención de sus demandas". Cf. Op. Cit. p.22.
} 
anteriormente asociadas a la "vida privada", por la valorización de culturas étnicas y/o religiosas, que consideran sus lealtades y sus valores grupales como prioritarios y no negociables -, pone en jaque la noción republicana del espacio público y del bien común.

Aunque esa dinámica haya producido una reacción ideológica, intelectual y política, en particular en Europa, en tomo a la defensa de los valores "nacionales" o republicanos, extendida de derecha a izquierda, es difícil creer que pueda haber un retomo al pasado. Nos encontramos en un universo muy distante del de la tradición laborista y socialista. En lugar de un valor societario común, el trabajo, tenemos una afirmación de valores diversos e inconmensurables entre sí; en vez de una radicalización de la similitud o de la igualdad, la radicalización de la diferencia; en lugar de la exploración, la dominación simbólica y la victimización; sustituyéndose, en definitiva, una utopía universal por utopías particulares; en vez de confianza en la acción humana, en el futuro y la historia, una incertidumbre y una desconfianza en la política.

La creación de puentes entre lo privado y lo público, promovida en particular por el feminismo, desempenó un importante papellibertario, pues pus o en el debate público ciertas dimensiones de la vida social que, en nombre del respeto a la intimidad de la vida privada, protegían sistemas de dominación y opresión. Pero, en la medida en que se pasa a un continuum entre lo público y lo privado, se elimina la tensión dinámica entre el individuo, el grupo y la sociedad nacional - tensión que alimentó la producción de utopías, cuyo horizonte necesariamente debe ir más allá del propio ombligo. Si la separación entre lo público y lo privado permitió formas de dominación que deben ser criticadas y superadas, ella representa la principal protección contra las tendencias autoritarias y totalitarias, sea del Estado o de la propia sociedad, y constituye un instrumento central de defensa de la libertad individual.

En tanto grupos que procuran el reconocimiento simbólico, las nuevas identidades tienen el efecto de democratizar los sistemas de valores y la vida cultural. Pero, una vez disociadas de la lucha por la igualdad a nivel del conjunto de la sociedad, ellas tienen un efecto limitado en la distribución de la riqueza. En el mejor de los casos, el resultado es la modificación de la posición relativa de los grupos identitarios al interior de un sistema de distribución de la riqueza social, el cual, en su conjunto, es poco afectado. ${ }^{47}$ Ellas tienen el potencial de normalizar la estructura de clases en el interior del grupo identitario, permitiendo el ascenso social de ciertas camadas: las nuevas identidades son un trampolín para nuevas elites que usan el tema identitario como recurso de negociación para tener acceso a mejores posiciones en el mercado de trabajo y a recursos públicos,

\footnotetext{
${ }^{47}$ Nancy Fraser discute los límites de la capacidad distributiva de los nuevos movimientos sociales centrados en el tema del reconocimiento identitario, suponiendo que una síntesis entre las antiguas formas de lucha contra la explotación económica sea posible. Se trata de una petición de principio sin demostración de viabilidad sociológica. Ver ¿De la distribución al reconocimiento?Dilemas de la justicia en la era pos-socialista.
} 
distribuidos de forma desigual al interior del grupo.

Así, las nuevas luchas sociales afectan ellugar relativo que los nuevos actores colectivos ocupan en el interior del mercado o en la alícuota de recursos públicos que les son otorgados, sin afectar necesariamente la distribución desigual de la riqueza en el conjunto de la sociedad. La desigualdad social hoy es vivida de forma múltiple, y las reivindicaciones, ya no son lanzadas contra las clases propietarias, sino contra las políticas públicas y los mecanismos de regulación del mercado de trabajo para grupos específicos.

El impacto de esas nuevas identidades sobre el proceso de democratización de las relaciones sociales es contradictorio. Por un lado, ellas renuevan la vida democrática, pues expresan grupos sociales (ia mujer, las minorías sexuales, los grupos étnicos) oprimidos en el proceso de construcción del Estado moderno. Por otro lado, esas identidades no sólo producen un impacto limitado en la distribución de la riqueza, como limitan las condiciones de existencia de un debate sobre la igualdad en el conjunto de la sociedad, ya que muchas veces están asociadas a un discurso y a prácticas institucionales construidas en torno a identidades colectivas impermeables.

De la misma forma que la demanda por derechos sociales que ignoran a los valores de respeto a la individualidad y a la libertad se transformó en totalitarismo, las nuevas reivindicaciones, asociadas a las llamadas "políticas de identidad" y al multiculturalismo, pueden transformarse en nuevas formas de racismo pos-moderno, como lo muestran los recientes ejemplos de la ideología de la nueva derecha en Holanda y Dinamarca y de los grupos fundamentalistas. En nombre de la diferencia, identifica da aquí con la cultura nacional, se pasa a excluir del acceso a la ciudadanía a aquellos que no comparten el mismo sistema de valores y de creencias.

La nueva onda de derechos, denominados generalmente "simbólicos", crea una contradicción entre democratización y democracia, de difícil resolución. En la medida en que la democratización de las relaciones sociales se realiza mediante la afirmación de identidades que corroen los sentimientos de comunidad - esto es, los sentimientos de ser parte del mismo mundo, de compartir problemas y valores -, se destruye, hasta cierto punto, una de las bases fundamentales de la ciudadanía: el sentimiento de pertenecer a un mundo de personas "iguales".

Las identidades colectivas centradas en el tema de la diferencia implosionan la posibilidad de contar con un marco sociológico unificado para el estudio de la desigualdad social, la cual hoy está referida cada vez más a la posición relativa de los grupos específicos dentro de la sociedad (mujeres, negros, latinos, emigrantes, homosexuales, en una progresión que podría ir a lo infinito). Esa forma de sensibilidad ante la desigualdad social propicia el desmembramiento del sentido de "sociedad", que deja de ser pensada y vivida como un conjunto de ciudadanos iguales y en la que el problema distributivo pasa a ser apreciado en términos de lo que "mi grupo" recibe en la 
"distribución de la torta". En caso de que la demanda de derechos a cargo de las nuevas identidades colectivas venga asociada a reivindicaciones distributivas, se presenta el riesgo de despolitización y de erosión del espacio público pues esas identidades cuestionan la política como producción de una utopía común y transforman el sistema de representación en un proceso de agregación de intereses entre diversos fragmentos sociales, imagen que se revela de manera ejemplar en el caso de los Estados Unidos ${ }^{48}$.

La noción de desigualdad social pasa a ser múltiple, de forma que un individuo concreto puede estar insertado en posiciones diferentes, dependiendo del grupo de referencia. Así, por ejemplo, desde el puno de vista del empleo o de la renta, puede encontrarse en la parte superior de la pirámide, pero su identificación con un grupo racial, étnico o de género, puede situarlo en posiciones inferiores. Las múltiples desigualdades han erosionado las nociones de clase social como base para crear identidades sociales sólidas.

La visión cada vez más globalizada de la estratificación social radicaliza la percepción de múltiples desigualdades sociales en términos de expectativas de acceso a la riqueza social dentro de una cultura de consumo globalizada. La identificación con un padrón de renta y de consumo global crea un problema político de difícil resolución, ya que las sociedades nacionales continúan siendo el principal locus de generación y de distribución de bienes.

La multiplicación de los derechos — particularmente la expansión del programa democrático tendiente a incluir no sólo los valores de libertad y de igualdad, sino también de alteridad (es decir, el derecho a ser diferente) —, impone una enorme presión a los sistemas sociales en los que la democracia aún presenta debilidades en razón de la permanencia histórica de enormes desigualdades sociales. Incluir el "derecho a la alteridad" en sociedades que todavía tienen dificultad para asimilar los valores "clásicos" de igualdad y libertad plantea nuevos riesgos de fragmentación social y de separatismo.

Así, el desarrollo de políticas de reconocimiento de las diferentes identidades étnicas, como la política de empowerment (empoderamiento) de las minorías de América Latina, podrá o bien fortalecer la democracia, o bien acelerar los procesos de desintegración de las sociedades naciona$\operatorname{les}^{49}$. La reconstrucción de identidades oprimidas tanto puede orientarse dentro de una lógica de reconocimiento de las diferencias, en un discurso en el que la clave de reconstrucción de la identidad opere en el sentido de valores compartidos por el resto de la sociedad, como puede

\footnotetext{
48 En este sentido, el análisis de Jürgen Habermas del espacio público, supone identidades colectivas que no tienen una relación instrumental. Ver Jürgen Habermas, "Struggles for Recognition in the Democratic Constitutional State".

49 Ver Cristian Gros, Políticas de la etnicidad. Ver Jürgen Habermas, op.cit.; Oliver Corten y Patricio Nolasco, "Pluralism eulturel, pluralism juridique et démocratie: les ambigúites du discours identitalre zapatiste".
} 
fundamentarse en una narrativa en la cual, en nombre de la opresión a que fuera sometido el grupo, termine creándose una dinámica de creciente alslamiento y rompimiento con la sociedad.

En Europa, la segunda lógica parece prevalecer en varios de sus países, pero no presenta mayores riesgos para la cohesión social, ya que el continente parece dirigirse a alguna forma de federalismo, conforme al cual algunas funciones estatales ya han sido transferi das a una instancia supra-nacional, la Unión Europea. En varios casos, las tendencias separatistas son promovidas por regiones afluentes, y sus reivindicaciones expresan, en cierta medida, un egoísmo colectivo, una "des-solidarización" con otras regiones más pobres.

En el caso latinoamericano, en que las instituciones democráticas y los mecanismos de integración social son mucho más frágiles, la "importación" acrítica de la experiencia norteamericana, construida históricamente a partir de la afirmación de la diversidad étnica, junto al auxilio internacional a grupos oprimidos, ha venido a promover el apoyo, a veces irresponsable, a las exigencias de pluralismo jurídico por parte de grupos indígenas. Como si la desigualdad social pudiese ser compensada con mecanismos simbólicos de autonomía jurídica, que muchas veces representan un retroceso hacia prácticas que no respetan los derechos humanos y conducen al fortalecimiento de oligarquías al interior de las comunidades "nativas".

Los procesos de desagregación de la visión de conjunto de la sociedad y la radicalización de las aspiraciones de derechos disociados de la elaboración política de proyectos societarios permiten la profundización del discurso y de las expectativas de democratización de la sociedad y, simultáneamente, el aumento de la desigualdad económica. Así, la fragmentación de la representación social ha hecho posible la paradoja del mundo contemporáneo: cada vez más democrático y cada vez más desigual.

\section{La crisis de representación política y el papel del Poder Judicial}

La historia de la transformación de los derechos de ciudadanía en las sociedades capitalistas democráticas puede ser interpretada como una transformación de las relaciones entre los Poderes Legislativo, Ejecutivo y Judiciario. En líneas generales y en términos simplificados, el período de oro del Legislativo estaría asociado a la fase de acceso al derecho al voto, mientras que la expansión de los derechos sociales habría significado el fortalecimiento del Poder Ejecutivo. Finalmente, en el período actual, el Poder Judicial ocuparía un lugar central.

Esa modificación de las posiciones ocupadas por los Tres Poderes no significa un simple reacomodo en la esfera del Estado de la influencia de cada poder y de sus posibilidades para actuar como árbitro o aún para imponerse alos otros, sino que está asociada, sobre todo, a la transformación de la representación social de la política y a las transformaciones societarias que han venido 
afectando el contenido y la organización de cada poder.

Lo cual se aprecia claramente, y retrospectivamente, en el cuadro del Estado de bienestar, que marca un período de auge del poder Ejecutivo, de expansión de la máquina estatal y de la tecnocracia, de inclusión sistemática de nuevas áreas bajo su égida (de la salud a la educación, de la ciencia a la tecnología y a las infra-estructuras), llamado a imponer la presencia de dicho poder no sólo sobre los otros poderes sino también sobre la sociedad, de donde extrajo su impulso inicial. Como vimos, tales transformaciones influenciaron igualmente al Poder Judicial, que se vio confrontado a la tarea de integrar nuevos sujetos y a expandir su jurisdicción, aproximando el Derecho a la demanda de derechos sustantivos de grupos específicos.

Si acompaflamos las hipótesis de Marcel Gauchet ${ }^{50}$, el creciente poder del sistema judicial en esta nueva fase estaría relacionado con el proceso de desacralización y de secularización del mundo, con el fin de las utopías sociales — orientadas por la creencia en un sentido de la historia , con el agotamiento del Estado de bienestar, asociado alos límites crecientes de la acción discrecional del Estado, a su vez pautados por las exigencias de inserción en la economía internacional, con el desenvolvimiento del nuevo individualismo ya no orientado por ideologías políticas o por la identificación con el espacio público. Esas transformaciones motivaron el debilitamiento y la pérdida del aura de la política partidaria y del poder político, tanto del Ejecutivo como del Legislativo.

Esos procesos transfirieron la representación de la política hacia al discurso de los derechos humanos. Tallenguaje sería la forma por la cual los actores sociales expresarían sus aspiraciones, lo que vendría a producir la paradoja de que la política no encontraría un lenguaje políticopartidario para expresarse. Mientras el discurso político-partidario exige opciones y supone posiciones diversas y conflictivas y suponen negociaciones y un cierto pragmatismo, el discurso de los derechos humanos es inclusivo y se construye en torno al mundo de valores morales absolutos.

Conforme a este análisis puede afirmarse que ellugar del Poder Judicial cambiá porque su papel en la sociedad se alteró como expresión del dislocamiento de la representación política hacia el discurso de los derechos humanos. Tal cambio fue concomitante con la transformación del propio poder jurídico, en razón de la constitucionalización del sistema político y de la juridicionalización del conflicto social. La constitucionalización del sistema político implica remitir la acción tanto del Poder Ejecutivo como del Poder Legislativo al control de las tribunales constitucionales. La juridicionalización del conflicto social conduce a una transferencia de las expectativas de atención de las demandas y la resolución de conflictos sociales hacia el Poder judicial, que sería el único

\footnotetext{
${ }^{50}$ Ver Marcel Gauchet, "Quand les droits de l'homme deviennent une politique".
} 
garante de la convivencia y el único poder confiable.

La dinámica de juridicionalización de las relaciones sociales propicia la transformación tanto de la política como de las actores sociales que intervienen en el juego político. Lo cual se expresa en la decadencia de las formas de participación político-partidaria y en la fragmentación de la representación social. En la esfera del Poder judicial, la constitucionalización del derecho significó una cierta aproximación de la tradición continental difundida por el código napoleónico con la tradición del derecho consuetudinario anglosajón en la medida en que la referencia creciente a cuestiones constitucionales y la importancia creciente del sistema judicial en la vida social dislocaron el papel tradicional del juez consagrado a aplicar las leyes hacia una posición más bien de intérprete activo de la ley. La propia diferenciación interna del Poder judicial, con la creación o el fortalecimiento de la figura del defensor de la ciudadanía transformado el Poder judicial en un actor político central.

Paradójicamente la juridicionalización de lo social marca un proceso de doble fragilización del Derecho: en el plano institucional, en la medida en que remite toda nueva legislación a sus fundamentos constitucionales e incluso alos derechos humanos; y en el plano de las relaciones cotidianas, en tanto induce una contractualización creciente de las relaciones sociales, en particular, las del trabajo, aunque también las familiares y la de los sistemas de previsión social, de educación y de salud.

Tanto la constitucionalización como la contractualización de las relaciones y expectativas sociales pierden la perspectiva específica de la ley como convención colectivamente compartida y como ordenamiento impositivo, colocándose más bien en el plano tanto de la individualización de los acuerdos y de los arbitrajes como de los derechos universales. En ambos casos, resulta erosionada la capacidad del Poder Ejecutivo y del Poder Legislativo para elaborar soluciones referidas a situaciones conflictivas - internas o externas - que exijan una renuncia, por lo menos parcialmente, de derechos adquiridos. La juridicionalización de las relaciones sociales perjudica, en particular, a las sectores más frágiles, distantes del acceso al sistema judicial.

La contractualización de las relaciones sociales permite, en nombre de la autonomía de las partes, la reintroducción de relaciones de poder y de opresión en el mundo del trabajo, mientras que la constitucionalización conduce a un distanciamiento del ciudadano con las decisiones y compromisos políticos asumidos por gobiernos democráticamente electos. Ambas tendencias presentan aspectos positivos: la primera expresa la individuación creciente de las relaciones sociales y la búsqueda de soluciones personales; la segunda, importa la defensa del ciudadano ante lo que se considera como el poder arbitraria del Estado. Pero tales tendencias contienen, con todo, enormes peligros para la consolidación de la vida democrática. En el primer caso, al construir un vínculo 
social al margen de la sociedad como si fuese un negocio particular; en el segundo caso, al desconocer que a vida política requiere de soluciones de compromiso y que en ella los miembros de la comunidad aceptan distribuir costas y beneficias. Ambos casos son una expresión profunda, en definitiva, de la desidentificación del individuo contemporáneo con una visión de lo social que exige sumisión a normas compartidas y un cierto sacrificio del interés personal en nombre del interés colectivo.

Las nuevas formas de representación colectiva, la pérdida de creencia en la política partidaria y en las ideologias de transformación social y o su sustitución por el discurso de los derechos humanos, debilitaron el papel ideológico y funcional del Estado como elaborador de estrategias capaces de controlar y de regular el proceso de modernización social. La fragmentación de intereses, como vimos, situó la lucha por los derechos humanos en el centro de la vida pública y fortaleció el papel del Poder Judicial.

Poniéndose de espaldas a los Poderes Ejecutivo y Legislativo, los procesos de juridicionalización del conflicto social y la constitución de las identidades colectivas presentan nuevos problemas para la gobernabilidad de la sociedad moderna. Décadas atrás, Samuel Huntington formuló el problema de la gobernabilidad como si se tratara de un (des)ajuste entre el ritmo de expansión de las demandas sociales y la capacidad del sistema politico o de los recursos disponibles por el Estado para procesarlas. ${ }^{51}$ En el actual contexto, la dinámica institucional ocasiona un dislocamiento de las demandas, realizadas directamente al Poder Judicial o elaboradas al margen del sistema político y, muchas veces, a espaldas del Estado (como en el caso de grupos religiosos fundamentalistas y, de forma más amena, de identidades colectivas independientes del sistema político nacional). Mientras en la situación anterior el peligro provenía de la implosión del régimen democrático en paralelo con la incapacidad del Estado para absorber las diferentes demandas sociales, el peligro hoy proviene del abandono moral de la esfera pública estatal, en razón de la pérdida de identificación con el sistema político organizado en tomo al Estado. La nueva crisis de legitimación en América Latina se presenta, en definitiva, no como un desbordamiento del Estado, sino como un vaciamiento del sistema político-partidario, expresado en la despreciable consideración reservada a los políticos, en el descreimiento en las elecciones como mecanismo para cambiar el destino de las sociedades y en la potentcial disposición a apoyar políticos aventureros, sin raíces en el sistema partidario.

\footnotetext{
${ }^{51}$ Samuel Huntington, Political Order in Changing Societies.
} 


\section{Capitulo III}

\section{La "sociedad civil", las ONGs y la globalización de las agendas sociales}

La crisis de las ideologías socialistas y las nuevas formas de gestión empresarial asociadas a transformaciones sociales y tecnológicas que disminuyeran la importancia del proletariado industrial, debilitando el mundo sindical y radicalizando el proceso de individuación — produjeron una "desradicalización" de la política partidaria y del antiguo clivaje izquierda-derecha. Ganar elecciones pasó a depender ahora de la capacidad para aglutinar las más diversas demandas sociales, lo que implicó un movimiento en dirección al centro político y una moderación de los discursos con vistas a no alienar potenciales aliados. Las nuevas técnicas de marketing electoral volvieron aún más inocuas o irrelevantes las cuestiones ideológicas. Las condiciones de administración de la economía, en fin, en un contexto de inserción creciente en la economía global, en conexión con la percepción de la importancia de los recursos externos para sustentar la estabilidad financiera y el crecimiento económico, de limitaron todavía más las opciones de diferenciación de los programas partidarios.

Para ganar las contiendas electorales los partidos tuvieron que moderar sus discursos, transitar entre los más diversos intereses, "desradicalizar", en fin, las expectativas. En lugar de actuar como portadores de utopías, los partidos se transformaron en administradores de presiones. La vida partidaria entró así en una crisis de representación política, pues la representación, al fin y al cabo, más que la expresión de intereses inmediatos debe ser la voz de los valores y de las esperanzas de los diversos sectores de la sociedad.

A medida que los partidos políticos fueron vaciándose o abandonados por falta de sustancia ideológica, la política "tradicional" pasó a ser vista en forma negativa, como un campo en e1 que prevalecen la vanidad y la corrupción, sufriendo así un proceso de desacralización, de modo que, para buena parte de la población, los partidos y los políticos perdieron autoridad, respeto y admiración, abandonando también la esperanza y el mensaje utópico que los acompanaran durante el siglo XX. Los cargos de gobierno perdieron el encanto asociado al ejercicio del poder político, que el Estado nacional supo extraer de las instituciones pasadas cuando el poder se presentaba como expresión de una voluntad divina. ${ }^{52}$

La separación entre la elaboración de las "causas sociales", dotadas de un fuerte ethos moral,

\footnotetext{
${ }^{52}$ Ver Marcel Gauchet, "Quand les droits de l'homme deviennent une politique".
} 
y el mundo de la política partidaria, tiene un doble origen. $\mathrm{Si}$, por un lado, la misma remite alos procesos anteriormente mencionados de "desencantamiento" de la vida político-partidaria (transformada en ejercicio de administración más o menos eficiente de la economía y de asignación de recursos en un abanico bastante limitado de posibilidades), por otro lado, como también vimos, refiere a un proceso paralelo y convergente, tal vez de consecuencias más fundamentales, tendiente a disociar las "grandes causas sociales" de los proyectos societarios inclusivos, distanciándolas de la vida político-partidaria.

Durante varias décadas, la síntesis social-demócrata hizo coincidir un proyecto solidario con una alternativa de política económica (el keynesianismo), uniendo políticas redistributivas y acumulación de capital, permitiendo la convergencia, por cierto conflictiva, entre los intereses de los sectores populares y los de los grupos dominantes de la sociedad capitalista; a lo cual debe sumarse la adecuación entre el progreso económico y el progreso social, así como la conciliación de la innovación tecnológica con la innovación social solidaria. Tal vez haya sido una excepción histórica que, en torno a la clase trabajadora, en un momento determinado del desarrollo capitalista, los grupos subordinados hayan participado de un proyecto societario que beneficiaba los intereses de la mayoría de la población y no entraba en oposición frontal con los intereses de los grupos dominantes. Tal situación habría sido posible, en todo caso, porque los grupos subalternos alcanzaron un enorme poder económico-organizacional (a través de los sindicatos) y el representativo (vía partidos políticos).

\section{La "sociedad civil"}

En la actual fase del capitalismo, observamos una disociación creciente entre Ias exigencias de elaboración de proyectos políticos, capaces de generar un amplio consenso social o de gobernabilidad, y políticas sociales distributivas; o más brevemente dicho, entre progreso económico y solidaridad. Tal disociación es el resultado de la distancia abierta entre ganadores y perdedores (estos últimos representados por todos los transformados en "obsoletos" o "incontratables" por el sistema económico). Los nuevos grupos marginalizados por la dinámica del capitalismo contemporáneo no disponen de poder político ni de capacidad de presión económica, ni tampoco consiguen transformar sus intereses, por lo menos hasta hoy, en un proyecto societario susceptible de integrar sus reivindicaciones a las exigencias de la dinámica económica. Movimientos como el MST en Brasil (Movimiento de los Sin Tierra), o los Zapatistas, en México, si bien lograron convertirse en un símbolo ético, en una espina en la conciencia social, no tienen capacidad para canalizar propuestas de reorganización de la sociedad o de formulación de programas políticos que abarquen a la mayoría de la población. 
La disociación entre política e ideales se tradujo en una disyunción entre la administración del Estado, a la cual se ven sujetos los partidos en el poder, y la producción de ideales morales, tarea que habría recaído en las organizaciones de la "sociedad civil", especializadas en la producción del discurso de protesta moral. A medida que los productores de "causas morales" se asumen como defensores y "representantes" de los sectores marginales, se consolida un proceso de distanciamiento entre la "lógica del sistema", en la que se verían atrapados los partidos parlamentarios, y las reivindicaciones de los grupos excluidos, vehiculadas por organizaciones no-gubernamentales.

Aun cuando ciertos políticos demagógicos procuren asumir una postura mesiánica junto a un discurso moralista, apolítico y distante de la vida partidaria (como en el caso de Collor en Brasil, de Fujimori en Perú o de Hugo Chaves en Venezuela), se trata, en general, de experiencias de corta vida, rápidamente desestabilizadas por la dinámica política y económica. En otros casos, especialmente en los países avanzados, partidos políticos surgidos de movimientos sociales, como los "verdes", viven permanentemente desgarrados entre la lógica de sus bases y sus exigencias "puristas" de estas últimas, y la realidad de su participación en la vida parlamentaria o en las alianzas de gobierno. Incluso, la actual experiencia del PT (Partido de los Trabajadores) en el gobierno federal de Brasil, hasta cierto punto pone en evidencia las contradicciones existentes entre la dinámica de la "sociedad civil" y la de los partidos políticos.

En este nuevo contexto, se han venido expandiendo también los grupos religiosos, deseosos de ocupar un espacio creciente en la esfera pública. Aunque el análisis de tal fenómeno no entre en los objetivos de este ensayo, es importante contemplar a los grupos religiosos entre los nuevos (o renovados) actores del sistema político contemporáneo o al menos considerar su impacto directo e indirecto en la representación política, sobre todo si se tiene en cuenta su cuestionamiento a los valores seculares que sirvieran de base para la construcción de la ciudadanía moderna.

El referido "dislocamiento" de las expectativas relacionadas con la política se expresa asimismo en una pérdida de identificación con las instituciones políticas representativas. Como resultado de ese dislocamiento asistimos a una convivencia entre la apatía o e1 descreimiento en las instituciones con periódicas explosiones contra gobiernos transgresores de principios de carácter legal o moral. En esas explosiones -como la producida en el impeachment a Fernando Collor, en la caída de Fujimori y en los levantamientos en Venezuela - los medios de comunicación, más que los partidos políticos o que los sindicatos, han venido cumpliendo un papel catalizador. 
Sin duda, los partidos políticos continúan siendo los principales procesadores de los intereses y demandas de la mayoría de la sociedad, pero su capacidad para expresar las dimensiones morales de la política o para representar las esperanzas de los sectores más desfavorecidos ha venido disminuyendo. El parlamento, oprimido entre el Poder Ejecutivo que monopoliza los recursos materiales y las capacidades tecno-burocráticas - y el Poder Judicial — que se adjudica la decisión final sobre la legalidad de las leyes — tiende a fragmentarse, viéndose colonizado por los más diversos lobbies económicos y sociales.

De esta forma, el espacio del discurso moral de la sociedad se ha venido desplazando hacia una galaxia de agrupamientos, denominada "sociedad civil". Dichos agrupamientos encuentran un fuerte portavoz en la prensa, la cual significa una valiosa ayuda para sus movilizaciones, para efectivizar sus denuncias, realizadas en nombre de "valores absolutos", contra comportamientos no idóneos de hombres y mujeres o de agencias públicas.

La valorización y la expansión de organizaciones que se autodefinen como "sociedad civil", simboliza y expresa la pérdida de centralidad de la clase obrera, así como la crisis de los partidos políticos, la retracción del Estado de bienestar y las crecientes dificultades de los gobiernos para enfrentar los nuevos desafíos de sociedades simultáneamente fragmentadas y globalizadas. Así, la "sociedad civil" ha pasado a ser considerada, en el imaginario social, como la única institución portadora de virtudes políticas, inclusive por parecer "no política", valorizada como si se tratara de un nuevo agente de transformación histórica y expresión de los deseos libertarios y de justicia social ante la falta de humanidad del mercado y del Estado. El distanciamiento creciente entre las activistas sociales, inspirados en una agenda de defensa de valores absolutos, y los partidos políticos, ha llevado a la caracterización de la "sociedad civil" como siendo la "auténtica" representante de la "sociedad" frente a un sistema político deslegitimado.

Como concepto, la "sociedad civil" transitó por un largo camino, habiendo adquirido los significados más diversos, según el lugar que le fuera asignado por cada sistema de filosofía social. ${ }^{53}$ Pero se trata de significados que hoy no contribuyen a aclarar el sentido específico que la sociedad le atribuye a dicho concepto. En los afios 60 y 70, la presencia del término en las medi os intelectuales estuvo particularmente ligada a su valorización por el marxismo gramsciano, pero su divulgación en un sentido próximo al actual está asociada a las luchas contra los regímenes autoritarios de América Latina y en los países comunistas, como expresión que denominaba a los grupos de resistencia organizada de la sociedad ante el poder

\footnotetext{
${ }^{53}$ Ver Norberto Bobbio, O conceito de sociedade civil.
} 
del Estado. Sin embargo, bajo los regímenes democráticos, las connotaciones de un universo naturalmente ético y de un mundo homogéneo, propias del período de lucha contra los regímenes autoritarios, perdieron actualidad.

En América Latina el debate reciente sobre la "sociedad civil" fue promovido por científicos sociales interesados en introducir una dimensión sociológica en la discusión sobre la democratización, en un debate por cierto más bien centrado en las instituciones políticas formales. El concepto utilizado por esos autores está fundamentalmente inspirado en la obra de Habermas e impregnado de fuertes connotaciones normativas.54 Se trata, en general, de elaboraciones semifilosóficas que, en lugar de promover estudios concretos sobre la "sociedad civil", sobre su diversidad y complejidad, ofrecen "casos" elegidos a dedo (en donde la experiencia brasilefia del presupuesto participativo y el forum Social Mundial suele tener un lugar asegurado), más bien destinados a confirmar las tesis generales.

El enorme prestigio que la "sociedad civil" posee hoy en los medios de comunicación de masas y en prácticamente todos los organismos internacionales han dado lugar con frecuencia a un uso acrítico o apologético de ese concepto por las ciencias sociales. Por lo tanto, se impone un análisis crítico del concepto, que no lo ignore pero que exija una explicación de cómo es construido y del porqué de su lugar en el imaginario y en la práctica social.

Los argumentos de filosofia política que en las últimas décadas han intentado recuperar el concepto de "sociedad civil", apelando a un fuerte contenido normativo, nos parecen, por lo menos desde el punto de vista sociológico, bastante frágiles. En general se trata de construcciones deductivas que culminan con la formulación de un concepto de "sociedad civil" cargado de wishful thinking. Así, Jean Cohen y Andrew Arato ${ }^{55}$, partiendo de la teoría social de Habermas, procuran alargar el horizonte de la práctica democrática, identificando la "sociedad civil" con un espacio público no estatal que conviviría al lado de la esfera de los intereses privados (la economía) y del Estado (en el que aparentemente estaría incluido el sistema político partidario).

De acuerdo a esta visión, la "sociedad civil" estaría formada por actores autónomos, capaces de enfrentar el mercado o el Estado, de generar nuevas formas de participación política y nuevos derechos, limitando de esa forma las tendencias a la privatizaciónlmercantilización y a la burocratización de la vida social. En general, falta claridad en la definición sobre quién formaría parte, concretamente, de la "sociedad civil". Arato y Cohen, por ejemplo, privilegian los movimientos sociales, mientras que Habermas subraya más bien el papel de las asociaciones y

\footnotetext{
${ }^{54}$ Cf. Una síntesis del trayecto de este concepto en Brasil en el libro de Sérgio Costa, As cores de Ercília.

${ }^{55}$ Ver Jean Cohen y Andrew Arato, Civil Society and Political Theory. Arato posteriormente aceptó varias críticas sin dejar de sustentar la relevancia del concepto. Ver "Uma reconstitução hegeliana da sociedade civil". En Brasil esta visión es sostenida por Leo Avritzer, "Além da dicotomía Estado/mercado" y por Sérgio Costa, op. cit.
} 
organizaciones, como las ONGs. En todo caso, más allá de estos problemas de imprecisión conceptual, lo cierto es que esos análisis padecen la dificultad propia del diálogo entre la filosofía social y la sociología, esto es, la de procurar identificar organizaciones sociales concretas a partir de marcos teóricos que definen esferas de acción social deducidas de principios abstractos. Así, las tres formas de racionalidad que orientarían la acción en la sociedad moderna — la administrativoburocrática; la mercantil o monetaria; y la solidaria o dependiente de la acción comunicativa — son identificadas con organizaciones sociales precisas: el Estado, el mercado/empresa y la "sociedad civil". Ahora bien; ninguna de esas esferas funciona a base de una racionalidad única, como lo demuestra, por ejemplo, la bibliografía acumulada por la sociología económica sobre la práctica efectiva de las empresas, ni tampoco las instituciones de la "sociedad civil" permanecen al margen de Ias tendencias a Ia burocratización o a la mercantilización.

En la vida social, las virtudes y las vicias nunca son el mono polia de determinadas instituciones. El espacio del "mundo de vida", que Habermas constantemente pretende delimitar, está presente en las intersticios de todas las organizaciones sociales ${ }^{56}$. A su vez, las organizaciones de la "sociedad civil"están imbricadas, en su mayoría, a las sindicatos, a las partidos, a las iglesias, a las empresarios, o han sido incluso creadas por ellos, además de mantener múltiples vínculos con el Estado.

Las realidades sociológicas de esas organizaciones varían con cada contexto nacional, evidenciando distintas formas de inserción en la sociedad y en el sistema político. La idea de que la "sociedad civil" representa un importante componente en la consolidación de la democracia presupone que los diversos subsistemas, en particular, las instancias representativas partidarias y el sistema judicial, funcionan de forma adecuada. Lo cual permitiría que la "sociedad civil" pudiese desempenar el papel de correa de transmisión entre el espacio público y el sistema político. Con todo, esto no es lo que ocurre en la mayoría de las países latinoamericanos - e incluso en varias países avanzados-, en las cuales la sociedad civil refleja un concepto hipostasiado, tendiente a sustituir la dimensión de la política por el discurso moral o a desconocer, como en el caso de organizaciones religiosas fundamenta listas — integrantes de la galaxia de la "sociedad civil"— las valores democráticos básicos.

La idea de una "sociedad civil" diferenciada y contrapuesta al Estado contiene, en particular en la tradición anglosajona, mayores dificultades de conceptualización, pues la noción misma de Estado es poco habitual, ya que las instituciones políticas no tienen existencia independiente de la sociedad (es sintomático, por ejemplo, que las funcionarias públicos sean llamados civil servants).

\footnotetext{
${ }^{56}$ La búsqueda de una asociación de las agentes de la libertad y de la autonomia social con formas sociales precisas está presente incluso en un autor de gran pertinencia, como Alain Touralne. Ver Critique de la modernité.
} 
Lo cual no significa que en esos países, los procesos anteriormente mencionados de desgaste de la política partidaria no hayan generado una actitud de disociación del sistema político tradicional por parte de los actores sociales. A su vez, en las países de la tradición europea continental, en las que la administración pública heredó una serie de privilegias y de prerrogativas del Estado absolutista, la crítica al Estado aparece más justificada pues encierra un cuestionamiento a los componentes autoritarios y a ia falta de transparencia de las administraciones públicas, aún vigentes en la vida pública.

A medida que la "sociedad civil" tiende a distanciarse del sistema político, en particular del sistema partidario, se reduce la importancia de la dimensión política asociada al parlamento, se intensifican los procesos de fragmentación social y se diluye la capacidad de desenvolvimiento de los proyectos societarios. En última instancia, se crea la ilusión antidemocrática de una "sociedad civil" que podria existir de espaldas al Estado.

En el contexto del debate sobre el neoliberalismo y en su uso mediático, el concepto de "sociedad civil" es vehiculado como una "tercera realidad" frente al Estado y al mercado. Los movimientos asociados a la lucha por la antiglobalización tienden a presentarse, concretamente, como una expresión de la "sociedad civil" y han conseguido imprimirle a ese concepto el poder evocativo de una dimensión social naturalmente buena, inmaculada, no impregnada de los maleficios del Estado o del mercado. En realidad, los partidos políticos -que incluso crean sus propias ONGs — se apropiaron del discurso sobre la "sociedad civil" de la misma manera que se ha vuelto una práctica común la participación de políticos y miembros del gobierno en encuentros del Forum Social Mundial.

El uso del concepto de "sociedad civil" por parte de algunos de sus autoproclamados representantes, equivale a la propia negación del concepto de espacio público. Si la "sociedad civil" es una dimensión de la esfera pública, ella no puede ser "representada" por ningún grupo, pues significaría el abandono de la idea de una esfera abierta. La esfera pública es pública pues constituye un espacio de diálogo, de encuentro de opiniones diferentes, que nadie puede representar o que ningún actor puede apropiarse ya que estaria destruyendo sus propios fundamentos, homogeneizando una realidad cuya condición de existencia es la diversidad ${ }^{57}$.

La auto-representación de la "sociedad civil" como una estructura homogénea favorece esta tendencia. En lugar de presentarse como un partido (esto es, como una parte) contrapuesto a otros, las organizaciones de la "sociedad civil" dificilmente debaten con sus congéneres, ni se constituyen, por lo menos explicitamente, a partir de la crítica a sus pares, sino en contraposición al Estado y al

\footnotetext{
${ }^{57}$ Lo más próximo a una "representación" de la esfera pública es la metáfora estadística del sondeo de "opínión pública", que no puede ser confundido, en ningún caso, con la esfera pública como tal.
} 
mercado.

La tentación por una apropiación monopolística del espacio público, si bien parece ser más fuerte en países con instituciones democráticas frágiles o en regímenes autoritarios, está presente también en el interior de la mayoría de las organizaciones de la "sociedad civil", en las que se pretenden encarnar valores morales absolutos, desvalorizando el sistema político o estatal. De tal forma, dichas organizaciones pueden contribuir a desestabilizar el papel de la esfera pública como espacio de diálogo y de elaboración de alternativas políticas y corroer la propia democracia, que es condición de la existencia de una "sociedad civil" autónoma.

Entretanto, en todos los países en que la sociedad democrática está sólidamente arralgada, no existen mayores cuestionamientos sobre el espacio específico que deben ocupar el Estado y las instituciones de administración pública con relación a las organizaciones cuya vocación pública está inspirada en el derecho civil privado. No es ese el caso de los países latinoamericanos, y menos aún de los países africanos. Cuando los gobiernos gozan de baja legitimidad o no son democráticos, la "sociedad civil" tiende a considerarse "más" legítima que el propio gobierno. En ciertas situaciones, hasta los grupos armados, como las FARC, en Colombia, pasan a reivindicar la representación de la "sociedad civil". Ciertamente, en contextos no democráticos, ese "substitucionismo" político es inevitable, pero en regímenes democráticos representa un retomo a prácticas que pueden desembocar en formas de mesianismo autoritario.

Uno de los principales peligros de la auto-representación de la "sociedad civil" reside en la manipulación política de la ideología de los derechos humanos. Con frecuencia las organizaciones de defensa de los derechos humanos enmascaran agendas políticas bien definidas, manejando un orden de prioridad bien distinto al de la universalidad de los valores preconizados, como se puso de manifiesto en la conferencia contra el racismo en Durban, en 2001. La lógica de esas organizaciones no es diferente a la de los viejos "frentes" promovidos por los comunistas, usando un discurso de denuncias centradas en las situaciones de no respeto alos derechos humanos pero asociadas de hecho a la lucha contra el "enemigo político".

La "sociedad civil", en un sentido laxo, esto es, como conjunto de organizaciones que reivindican una representación moral superior con respecto al gobiemo y a las instituciones públicas, debe ser entonces analizada en sus específicos contextos políticos y sociales. Sus reivindicaciones y utopías pueden ser - y generalmente son - componentes centrales de renovación de la vida democrática, pues crean y defienden nuevos derechos y valores. Con todo, en ciertos casos las organizaciones de la "sociedad civil" pueden defender posturas autoritarias y reaccionarias, tal como lo revela la historia pasada y presente, desde grupos de extrema derecha a religiosos fundamentalistas. El prestigio de a "sociedad civil" tanto refleja su importancia como 
fuente de nuevas prácticas sociales como traduce el malestar de la sociedad con sus instituciones políticas. En la práctica, las relaciones entre los partidos políticos y la "sociedad civil" tienden a ser complementarias y conflictivas. Complementarias, pues las partidos (y los gobiernos) parasitan a la "sociedad civil" con vistas a identificar nuevos temas y causas que les permitan mantener una fuerza moral, después de que ellos mismos evacuaran, en la práctica, las ideologías que alimentaran su creatividad y visión de futuro.

Si las organizaciones de la "sociedad civil" tienden a recortar la legitimidad de los partidos y de los gobiernos constituidos, ellas no constituyen una amenaza para los regímenes democráticos sólidamente constituidos, pero representan un potencial de desmoralización de la vida política en países con democracias menos consolidadas.

Los partidos políticos, durante un largo período, pretendieron ser a la vez la expresión de los individuos y de las grandes causas o de los intereses del conjunto de la sociedad. La convergencia de solidaridad y de individualidad, de valores comunes y del respeto a la autonomía individual está asegurada, en los regímenes democráticos, por los mecanismos electorales, a través de las cuales los ciudadanos delegan a los partidos y a los políticos el poder de defender sus intereses particulares (individuales) y comunes (de grupos o del conjunto de la sociedad).

La separación entre los "portavoces" de los derechos humanos y los representantes políticos electos tanto expresa como genera una crisis de representación de los partidos políticos. Esta contradicción se presenta de forma más dramática cuando la expresión organizada de la "sociedad civil" recae en ONGs, constituidas, en su mayoría, por un número extremadamente pequeno de individuos. Como esas organizaciones no aspiran a tomar el poder, esa situación no presenta mayores riesgos para el sistema político, pero cuando están asociadas, directa o indirectamente, a grupos que objetivan el poder, el discurso de la "sociedad civil" guarda ciertas semejanzas con los antiguos partidos "vanguardistas" revolucionarios, conformados por minorías auto-representadas como encarnación de valores morales absolutos.

\section{El mundo de las ONGs}

Las ONGs corresponden a un conjunto amplio de instituciones, cuya definición es de corte negativo, vale decir, organizaciones privadas que no objetivan el lucro. En la práctica, ese universo incluye desde antiguas organizaciones filantrópicas de carácter religioso - generalmente basadas en el trabajo voluntario - , pasando por fundaciones y asociaciones de barrio, hasta organizaciones más bien de fachada, tanto de políticos, que Ias usan para canalizar recursos públicos, como de empresarios, que encuentran en ese formato una solución más lucrativa de 
gestión empresarial $^{58}$.

A pesar de la continuidad existente entre las antiguas formas de acción filantrópica y las ONGs, la ONG "moderna", expandida enormemente a partir de los aõos 70, es una estructura de un nuevo tipo, tanto en términos político-culturales como organizacionales. La ONG contemporánea representa una institución especializada en la creación, la defensa y la diseminación de derechos humanos al tiempo que tiende a reivindicar el monopolio de esa área en el discurso político. En términos organizacionales las ONGs están formadas, en general, por profesionales dedicados exclusivamente a las "causas sociales".

Existen los más variados tipos de ONGs, la mayoría enanas (muchas veces mono o bipersonales. Una tipología posible se relaciona a la adscripción u origen. Así, pueden ser enumera de as las Pongs (ONGs ligadas a partidos politicos), Bongs (asociadas a "business", esto es, dependientes de empresas), Ronges (ONGs asociadas a grupos religiosos, partidos), Songs (ligadas a sindicatos), ete. Otras divisiones enfatizan: a) el carácter local, nacional o transnacional; b) el carácter voluntario o profesional; c) el área de actuación. Tal clasificación es ilustrativa de la diversidad de orientaciones que pautan estas organizaciones, pero en la práctica, ninguna ONG pertenece a un modelo "puro" de organización o de actuación.

Podemos identificar dos grandes tipos ideales de ONGs: las orientadas a defender causas (en inglés, advocacy) y las que desenvuelven prácticas sociales "ejemplares". El principal objetivo de las primeras es la realización de actividades de impacto mediático, actuando muchas veces en los límites de la ley, como forma de movilizar la opinión pública en torno a sus banderas. Las segundas se dedican a desarrollar, en cambio, proyectos sociales concretos, lo cual no excluye el objetivo de llamar la atención pública respecto a sus blancos de acción.

El mundo de las ONGs no representa una dimensión autónoma de la sociedad, pues mantiene variadas relaciones, muchas de el las de dependencia directa, con otras esferas de la vida social. Esta situación, que en principio es un dato positivo, exige un análisis detallado y concreto respecto al papel de las ONGs en cada contexto social más que su elevación al estatuto de nuevo agente del progreso histórico.

La inserción internacional es un rasgo característico de la mayoría de las ONGs. Tal como lo indica Sérgio Costa,

[ ... ] solamente cuando se toma en consideración el complejo juego de interpenetraciones, de alianzas sociales y alianzas transnacionales se puede entender, por ejemplo, por qué temas como el de medio ambiente, la igualdad de género o la lucha contra la discriminación racial ganaran en la agenda política y

\footnotetext{
${ }^{58}$ Sobre las dimensiones globales de este sector y la representación de algunos casos nacionales, cf. Lester M. Salaman et al., La Sociedad Civil Global: las dimensiones del sector no lucrativo.
} 
académica brasilefia una importancia desproporcional al peso político de los actores sociales que representan en el contexto nacional ${ }^{59}$.

La inserción internacional de las ONGs en los países en desarrollo se construyó a partir de la captación de apoyos financieros marcados por agendas específicas. Así, el mundo de las ONGs reprodujo en cierta forma las desigualdades entre el Norte y el Sur. La agenda de la mayoría de las ONGs (por ejemplo las dedicadas a temas ambientales o a políticas de control de natalidad) expresa preocupaciones, sensibilidades y prioridades más bien definidas en las casas matrices de los países centrales. No siempre los apoyos se expresan en forma impositiva, pero, en general, la dependencia del financiamiento internacional no deja de influenciar la orientación de las ONGs de los países menos desarrollados.

Aunque no existan análisis sistemáticos a escala internacional sobre la composición social y la trayectoria de los dirigentes y participantes de las ONGs, estudios alslados muestran que, más allá de su función como una importante fuente de empleos para líderes locales de barrios pobres o de minorías étnicas, ellas absorben una buena cantidad de egresados del sistema universitario, en particular, de graduados en las disciplinas de las ciencias sociales. Inclusive han comenzado a surgir cursos universitarios orientados a formar futuros operadores de ONGs.

El papel y el peso político de las ONGs en cada sociedad, como ya indicáramos respecto a la "sociedad civil", dependen del contexto societario (así, en la mayoría de los países musulmanes fundamentalistas, en Siria, en China y en Cuba son, en general, prohibidas o "filtradas" por el Estado). En África negra, cuando su funcionamiento está permitido, las ONGs absorben buena parte de los cuadros de la clase media con potencial para dirigir los negocios del Estado. Financiadas en su casi totalidad con recursos externos, ellas ofrecen salarios "internacionales" o de un nivel muy superior alos salarios de los funcionarios públicos, lo que permite que sus miembros mantengan cierta autonomía y distancia crítica con respecto a las prácticas de corrupción diseminadas en la función pública. Los presupuestos que las ONGs manejan son cada vez más voluminosos — incluso una parte significativa del total de los recursos de la cooperación internacional se destina directamente a la "sociedad civil" lo que transforma esas organizaciones en verdaderos centros de poder, capaces de cuestionar, en los forums internacionales, la legitimidad de los gobiernos establecidos.

En América Latina, el peso político de las ONGs es, en general, menor, aunque su influencia ha venido creciendo en forma constante, principalmente al impulso de los procesos de democratización y del aumento de los problemas sociales, tales como la desorganización urbana y la intensificación de la violencia. A su vez, los gobiernos y las instituciones internacionales

\footnotetext{
${ }^{59}$ Ver Sergio Costa, "A construção de razão no Brasil".
} 
procuran apoyarse en las ONGs para realizar acciones puntuales y creativas, valiéndose de ellas para enfrentar la falta de recursos, el empecinamiento y la corrupción de la máquina burocrática.

El universo de las ONGs en América latina se ha diversificado enormemente desde los afios 70, época en que eran financiadas fundamentalmente por fuentes externas, dirigidas a apoyar la resistencia alos regímenes autoritarios. En las últimas décadas, la importancia relativa de los recursos externos ha disminuido, habiendo aumentado, en cambio, la de los recursos públicos, así como también la de las empresas, influenciadas por el discurso de la empresa-ciudadana, cuya participación en proyectos sociales se ha ampliado sensiblemente en países como Brasil.

En Europa, aún siendo importantes como fuentes de empleo, las ONGs tienen un peso político menor, dada la mayor solidez del sistema de servicios sociales ofrecidos por el Estado. En ciertos países, como en Francia, las ONGs funcionan bajo subcontratos del Estado y/o preparan el terreno para la entrada de los servicios públicos en "barrios difíciles". Buena parte de las principales ONGs en los países desarrollados tienen como orientación principal la cooperación internacional.

Aunque el tema de la compleja relación entre los medios de comunicación y la democracia haya inspirado una enorme bibliografía así como un conjunto de debates fuera del alcance de este ensayo, no podemos dejar de indicar la afinidad existente entre los medios de comunicación de masas y los procesos que llevaron al fortalecimiento de la "sociedad civil" y de las ONGs. A pesar de las importantes y obvias diferencias entre los dos actores, hay una fuerte afinidad entre ellos: ambos reproducen y aumentan su radio de influencia gracias a la creciente disyunción entre la opinión pública, la opinión de carácter político-partidaria y el Estado.

Para las ONGs, el acceso a los medios de comunicación de masas es fundamental, ya que ellas no poseen sus propias "bases" sociales y los lazos que las ligan a su potencial público son frágiles o bien activados en función de acontecimientos específicos. Incluso, los propios grupos sociales que ellas procuran representar o expresar están, en general, muy poco estructurados y, la mayoría de las veces, no disponen de recursos como para tener un impacto directo en el sistema económico o político. Por eso, parte de sus actividades tienen como objetivo alcanzar un impacto mediático. Para ellas existir implica capacidad de llamar la atención de la prensa, apelando incluso a acciones sensacionalistas, a menudo desplegadas en ellímite de la legalidad, como en el caso, por ejempIo, de la actuación de ciertos grupos ambientalistas.

En las sociedades democráticas contemporáneas, los medios de comunicación son particularmente sensibles al tipo de mensaje de denuncia moral. O dicho de otra manera, dada su auto-representación como conciencia de la sociedad y su capacidad efectiva de influenciar la opinión pública, los medios de masas tienden a presentarse como la expresión moral de la sociedad. No obstante, aunque cumplan un papel social importante, dichos medios no dejan de ser sucedáneos 
de mecanismos efectivos de participación y de discusión política.

Las ONGs presentan tres grandes desafíos para la dinámica democrática. El primero, es el de la responsabilización, o mejor dicho, de la desresponsabilización social del Estado. Tanto los gobiernos como las instituciones internacionales tienden a transferir hacia las ONGs sus responsabilidades en materia de servicios sociales. Lo cual de alguna manera explica la aparente paradoja del amplio suceso de la "sociedad civil" y de las ONGs como su principal expresión, ya que son promovidas tanto por aquellos que critican el modelo neoliberal como por sus defensores.

La mayoría de las organizaciones que se autodenominan "sociedad civil", como vimos, se posicionan explícitamente contra el neoliberalismo y, en general, contra la globalización. Con todo, las instituciones internacionales y empresariales asociadas al neoliberalismo y a la globalización desenvolvieron en la última década una cruzada contra la ineficiencia y la corrupción del Estado, contra su papel como productor directo de bienes y servicios públicos. Así, la crítica al Estado, impulsada desde la "sociedad civil", es reapropiada por esas instituciones, que se muestran incluso dispuestas a financiar las instituciones de la "sociedad civil" como forma de disminuir el papel del Estado, transfiriendo responsabilidades a las ONGs. De hecho, las ONGs, ante la inercia de la máquina estatal, tienen la ventaja de una enorme flexibilidad y creatividad. Ellas son, además de promotoras de causas sociales, centros de experimentación de nuevas prácticas y de soluciones para los desafíos de un mundo en mutación, confrontado constantemente a nuevos problemas. A la actuación de las ONGs en la dimensión pública, se corresponde, en el campo del mercado, la de las empresas start-ups (pequenas empresas con gran capacidad de innovación tecnológica), pues las grandes corporaciones enfrentan el mismo problema que la máquina del Estado, esto es, el peso de la inercia interna. No obstante, si bien en el caso de las start-ups la dinámica de mercado favorece la absorción de las experiencias exitosas por las grandes empresas, en las relaciones entre las ONGs y el Estado esa dinámica es más compleja. El peligro consiste, en efecto, en que el Estado, habida cuenta de la escasez de recursos y de las prioridades políticas, utilice las ONGs para desentenderse de sus responsabilidades, no asuma las experiencias exitosas o utilice solamente experiencias alsladas como "vitrina publicitaria".

Por tanto, el desafío consiste en relacionar las redes horizontales (representadas por las ONGs con capacidad de movilización local y porosidad social) con las estructuras verticales del Estado, el cual posee recursos y tiene un alcance nacional, así como crear un círculo virtuoso en el que los respectivos espacios sean respetados ${ }^{60}$. De lo contrario, la acción de las ONGs tendrá el efecto paradojal de aumentar la heterogeneidad y la distancia al interior de los sectores más pobres,

\footnotetext{
${ }^{60}$ Cf. Bemardo Sorj, brazi/@ digitaldivide.com: Confronting Inequality in the Information Society (disponible en www.bemardosorj.com).
} 
ya que, en la mayoría de los casos, ellas actúan puntualmente, se concentran en las grandes ciudades y en determinadas áreas poblacionales, en general beneficiadas por la existencia de liderazgos locales emprendedores o por su capacidad para absorber la propia acción de las ONGs. Obviamente, no se trata de negar el valor concreto de esas iniciativas, sino de tener en cuenta que la disminución de la desigualdad social depende fundamentalmente de una acción estatal orientada hacia los sectores sociales con menos condiciones de absorber apoyos externos, de elaborar propu estas y de reivindicar recursos.

El segundo problema suscitado por las ONGs es el de la representación. Ellas no fundamentan su legitimidad, en efecto, a partir de la representación numérica de los ciudadanos, sino en un ethos moral y en el valor intrínseco de las causas que defienden. En la medida que algunas ONGs y otras organizaciones de la "sociedad civil" se proclaman como la expresión de la "sociedad civil organizada", reproducen todos los errores y los defectos de las antiguas organizaciones vanguardistas, ya que suponen que preexiste una "sociedad civil" desorganizada, homogénea y naturalmente virtuosa, a la que sólo falta darle la voz. Las contradicciones de la sociedad se reproducen así a nivel de las ONGs. ¿En virtud de qué criterio una ONG sería más representativa que otra? ¿Cuál es e fundamento de a legitimidad de una ONG y no de otra para "representar" una "causa" en foros internacionales?

Para ciertos autores as ONGs representan el fundamento de una futura "sociedad civil" internacional. Como expresión de una voluntad utópica ${ }^{61}$. Esa visión es legítima. Pero cuando dicha visión se confunde con la realidad concreta, sea por activistas, sea por sociólogos ${ }^{62}$, se vuelve analíticamente insustentable y política mente irresponsable. Ciertos teóricos, compenetrados con la idea de una "sociedad civil" global, descartan expeditivamente al Estado a la hora de preconizar una sociedad cosmopolita, en la cuallas ONGs son vistas como el esqueleto de una "sociedad civil" internacional. Pero, como ya seiíaláramos, ellas mismas reproducen las disimetrías del sistema internacional y la diversidad de cada sociedad.

Finalmente, el tercer problema es el de la asociación de ciertas ONGs con el concepto de empowerment, difundido, en particular, por el movimiento feminista norteamericano y hoy alimentado tanto por fundaciones americanas como por las instituciones internacionales. La propia dificultad de traducir ese concepto a las lenguas latinas, más allá de su origen anglosajón, indica su asociación a una tradición política que toma como punto de partida alos individuos, considerándolos al margen del sistema político y de las ideologías partidarias.

La idea de empowerment, en cierta forma equivale a la versión liberalradical de la

61 Como la expresada, por ejemplo, por Rubem César Fernandes en "Threads af Planetary Citizenship". 62 Por ejemplo, UIrich Beck, op. cit. 
"conciencia de clase" marxista - que define a la clase social como un ente preexistente a la conciencia de sí misma. En ambos casos se supone la preexistencia del grupo dominado, al que bastaría con suministrarle los instrumentos adecuados para que asuma su propio destino. Así, en el caso del empowerment, las mujeres, los negros y los indios serían, por definición, grupos subordinados, susceptibles de ser esclarecidos con vistas a que asuman sus intereses en tanto grupos con identidades específicas.

La ideología del empowerment reproduce los mismos errores que la ideología marxista, o sea, supone que el grupo preexiste a la ideología y que alguien del exterior está en condiciones de conocer la verdadera identidad de los oprimidos. Esa contradicción, inherente a cualquier disposición de intervención social fuera de los límites del propio grupo, incurre en riesgos enormes, los cuales, siendo inevitables, deben ser objeto de una permanente reflexión en los proyectos de acción social. El primero de esos riesgos es el de la colonización externa, debida a la exportación de modelos identitarios surgidos en contextos societarios muy diferentes. El segundo es el de la imposición de una forma de intervención política ajena a las tradiciones locales, llamada a danar todavía más el sistema de representación política de los grupos subalternos, cuando no a desestabilizar el conjunto del sistema político.

El análisis sociológico sobre las ONGs y la "sociedad civil" todavía está dando sus primeros pasos. Serán necesarias investigaciones detalladas de los procesos de encapsulamiento político, de canalización y control de recursos nacionales e internacionales, de los sistemas internos de organización y funcionamiento, en fin, de las relaciones de poder y de las nuevas formas de burocratización por ellas promovidas. El análisis social crítico no puede dejar de cuestionar los procesos por los cuales se constituye el discurso sobre la "sociedad civil" internacional, como las problemáticas discutidas en sus foros y cómo ellas reproducen relaciones de poder que traspasan el conjunto de la sociedad y del sistema internacional. El análisis critico de las ONGs no implica desconocer el papel que ellas tienen como uno de los principales vectores de solidariedad, de innovación social y de las nuevas prácticas democráticas, sea actuando como generadoras de propuestas inéditas de reconstrucción social, sea promoviendo o catalizando auténticos movimientos sociales o realizando acciones humanitarias.

\section{¿La reconstrucción del mundo por los derechos humanos o por el mercado?}

Bajo el rótulo general de "período populista", tiende a caracterizarse un período, extendido durante gran parte del siglo XX, en el que los países latinoamericanos procesaron la integración política y social de los sectores populares dentro de un sistema de derechos 
ciudadanos. Esos procesos de integración divergieron enormemente de país a país. En ciertos casos la integración social — particularmente considerada en términos de acceso a la educación y a la salud —, fue extremadamente amplia y exitosa, como en la Argentina, gracias, en particular, al peso de los sindicatos en una sociedad precozmente urbana y carente de mano de obra. Pero la Argentina fracasó en la consolidación de un sentimiento de comunidad cívica nacional, por la brecha abierta en la cultura política por el peronismo, que, a su vez, se alimentó de la herencia de una elite reaccionaria y de las desventuras del partido radical en los afios 20.

En otros casos, como en Brasil, la extrema desigualdad social y la limitada integración de la población alos servicios públicos fueron parcialmente compensados por un dinamismo económico, por una frontera abierta, así como por una cultura religiosa sincrética, la mezcla racial, la movilidad geográfica y social, el surgimiento de una clase media urbana permeable a la cultura popular y a una industria cultural creadora de espacios virtuales de convivencia intra-clasista. Así, la enorme distancia social y económica no se transformó en distancia cultural, lo que constituye, sin duda, uno de los grandes méritos de la sociedad brasilefia.

El mundo andino presenta, por su parte, rasgos muy diversos. De un lado, Chile, país con un Estado centralizador que, a partir de la Guerra del Pacífico mostró una alta capacidad de integración política y de generación de valores nacionales, pese a sus elevados niveles de desigualdad social. De otro lado, países como Bolivia, Peru y Ecuador, en los que el peso de los grandes latifundios recayó sobre la población indígena, aislándola social y culturalmente del sentimiento de pertenencia a una comunidad nacional de ciudadanos. Finalmente, para poner otro ejemplo más, Uruguay y Costa Rica aparecen como los países que consiguieron el mayor éxito de integración social, política y cultural.

Todos esos modelos de integración social entraron en colapso a partir de los afios 60 y 70 , en razón del agotamiento del padrón de crecimiento econámico y de la imposibilidad de mantener los sistemas tradicionales de cooptación de sectores emergentes mediante el uso de recursos públicos. La explosión urbana, la expansión de las expectativas y de los valores democráticos determinaron la crisis del modelo de crecimiento y del sistema de integración tanto de las clases medias como de parte del mundo del trabajo, crisis que se expresara en una inflación galopante y en la estagnación económica.

La inflación fue el principal síntoma de la incapacidad de los Estados para imponer una disciplina al conflicto distributivo; ella alimentá también alos sectores rentistas y especulativos de la sociedad golpeando duramente alos sectores más pobres de la población. En ese contexto, el principal recetario disponible para enfrentar la inflación y obtener crédito internacional desarrollado por los organismos internacionales de financiamiento y apoyado, en particular, por los 
Estados Unidos - propuso un conjunto de reformas estructurales, tendientes a alivianar los gastos del Estado a través de privatizaciones, de reformas del sistema de previsión social y tributario, de una mayor apertura, en fin, de la economía al exterior y de reformas en la legislación laboral.

Se trata de una agenda destinada a transformar radicalmente el modelo de integración social hasta entonces vigente en América Latina, en el que el Estado ocupaba un lugar central en la cooptación de grupos sociales emergentes. La aplicación de esta agenda fue posible porque el antiguo modelo se había agotado, siendo visto por diversos sectores de la población como un sistema de distribución de privilegios, incapaz de generar crecimiento económico o de ofrecer servicios públicos universales y de calidad. Dicho de otra manera, buena parte de las reformas estructurales, incluyendo las privatizaciones, fueron aceptadas o aún apoyadas por la población, no sólo porque eran presentadas como necesarias para el combate contra la inflación, sino porque el Estado, que desempenara un papel central en el desarrollo de América Latina en el siglo XX, pasó a ser percibido como una fuente de privilegios, de corrupción, de ineficacia y de opresión burocrática.

Ahora bien; aunque el programa de reformas estructurales fue implementado, con mayor o menor profundidad, en todos los países de América Latina, su impacto fue diferente en cada país ${ }^{63}$. Las consecuencias de dichas reformas dependerán tanto de la extensión previa de derechos sociales como de los sectores afectados (así, por ejemplo, no es lo mismo el caso argentino, en donde la mayoría de la población asalariada estaba integrada al sistema de protección social, que el peruano o el brasileno, en que parte considerable de la población urbana se encontraba en el sector "informal"). Las resultantes finales de estos cambios también dependerán de la forma como fueron realizadas las privatizaciones y de como fueron montadas las agencias de regulación de las concesiones de los servicios públicos (en este sentido se advierten claras diferencias entre el asalto organizado a los cofres públicos por parte del gobierno de Menem y la "civilidad" de los gobiernos democráticos del Chile pós-Pinochet o de Fernando Henrique Cardoso en Brasil). A lo cual deben agregarse las diversidad de políticas sociales (así, por ejemplo, mientras la educación pública, primaria y secundaria se expandió en el Brasil de los anos 90, tanto en términos absolutos como relativos, sufrió en cambio un fuerte proceso de privatización en la mayoría de los países del continente) ${ }^{64}$.

De todas maneras, vistas en su conjunto, las reformas estructurales no trajeron mayor igualdad social. Ante esta situación, economistas y organismos internacionales, en particular, el Banco Mundial, comenzaron a promover "políticas focales", esto es, la concentración de los

\footnotetext{
${ }^{63}$ Sobre el proceso de reformas econômicas en América Latina, ver Juan Carlos Torre, El proceso político de las reformas económicas en América Latina.

${ }^{64}$ Ver Bernardo Sorj, "La relación público/privado en el Brasil".
} 
recursos del Estado en "públicos-blanco" bien definidos, dirigidos generalmente alos sectores más pobres de la población o a segmentos específicos (mujeres, grupos étnicos, ete.).

La contraposición entre servicios universales y políticas focales, que hoy informa el debate entre economistas en América Latina, como toda contraposición obscurece, más que ilumina, los problemas en cuestión. En efecto, ninguna sociedad posee solamente servicios universales o "políticas focalizadas". Estados Unidos, país de las "políticas focalizadas" posee servicios universales; a su vez en Europa y en Canadá conviven políticas focalizadas con políticas dominantes de servicios universales. Aunque las comparaciones dejen de lado innumerables factores históricos, los resultados que éstas arrojan, en términos de igualdad social y de eficacia de las inversiones (en particular en el área de salud) favo.recen el modelo de servicio universal, cuyo talón de Aquiles es su sustentabilidad frente al aumento de la longevidad y la disminución de la taza de natalidado Por otro lado, en países como Brasil, políticas aparentemente universales encubren prácticas focales tendientes a favorecer a los grupos sociales más ricos de la población.

Las reformas estructurales, en todo caso, marcan un giro histórico en las sociedades latinoamericanas en el sentido de cuestionar un modelo pautado por el estado-centrismo de las elites y las clases medias. La integración de nuevas generaciones de clases medias en los circuitos internacionales de nego cios y servicios, la orientación de la sociedad hacia expectativas de consumo definidas por padrones globales y la pérdida de legitimidad de la política o de los políticos pusieron en cuestión las relaciones entre el Estado, la sociedad y los diferentes grupos sociales, exigiendo una redefinición de esas relaciones. Ese proceso está en curso y su desenlace parece aún incierto.

Pero si las llamadas reformas estructurales implican un paso en la dirección hacia una mayor disciplina social, ellas no conforman una propu esta de organización de la sociedad. Los organismos internacionales, al observar que las reformas económicas no transformaron las prácticas consuetudinarias de tratamiento de los recursos públicos, ni disminuyeron los problemas sociales, comenzaron a admitir la existencia de una problemática institucional, a ser tenida en cuenta junto con las reformas económicas. Pues bien, si las propuestas de las instituciones financieras internacionales ya presentaban problemas en relación con la economía, debidos a la propensión a aplicar un recetario universal ciego a las especificidades nacionales, al pasar a enfrentar el tema institucional, por naturaleza mucho más ligado a circunstancias históricas locales, las fórmulas propu estas resultarán todavía más lastimosas.

La nueva agenda institucional tuvo como fundamento la movilización de dos tipos de conceptos y propuestas: a) el fortalecimiento de la "sociedad civil" y del "capital social"65,

\footnotetext{
${ }^{65}$ Ver respectivamente www.worldbank.orglcivilsociety y www.worldbank.orglwbplscapital.
} 
empleando en ambos casos conceptos que no interferirían ni en el mercado ni en el sistema de distribución de riqueza y que tendrían la virtud milagrosa de mejorar la sociedad; y b) el uso de modelos institucionales de best practice (mejores prácticas) y benchmark (estándar de referencia) en las áreas de servicios públicos, ya sea de salud, de educación o de justicia; modelos inspirados, en general, en la experiencia estadounidense.

En un retorno a las primeras y más primitivas elaboraciones de la teoría de la modernización de los anos 50 esos conceptos procuran identificar características que tendrían consecuencias virtuosas y universales sobre la sociedad. Así, tal como lo sostiene el texto del site del Banco Mundial $^{66}$, el elixir del "capital social" permitiría:

Crimenlviolencia: Valores y normas compartidas pueden reducir o mantener bajos niveles de violencia en las comunidades. Personas que mantienen relaciones informales con sus vecinos pueden vigilarse entre sí y "policiar" la vecindad.

Economía \&: comercio: Hay evidencias crecientes de que el comercio a nivel macro es influenciado por el capital social - un recurso de propiedad común cuyo valor depende del nivel de interacción entre las personas.

Educación: Evidencias considerables indican que el envolvimiento de la familia, de la comunidad y del Estado con la educación mejora los resultados.

Medio Ambiente: El gerenciamiento de los recursos de propiedad común supone una cooperación con el objetivo de asegurar la sustentabilidad de los recursos para el beneficio de todos los miembros de la comunidad, en el presente y en el futuro.

Finanzas: Un sistema de finanzas estable, seguro y justo es primordial para el crecimiento sustentable.

Salud, nutrición y población: investigaciones recientes muestran que cuanto menor es el nivel de confianza de la población, mayor es el promedio de la taza de mortalidad.

Información tecnológica: [...] tiene el potencial de aumentar el capital social, funcionando, en particular, como un puente entre el capital social capaz de conectar actores con recursos, relaciones e informaciones más allá de su ambiente inmediato.

Pobreza \& Desarrollo Económico: [...] especialistas en desarrollo y crecimiento están descubriendo la importancia de la cohesión social para que las sociedades prosperen económicamente y para que el desarrollo sea sustentable.

Desarrollo Rural: El capital social afecta la capacidad de la población rural para organizarse para el desarrollo. El capital social ayuda alos grupos a realizar actividades claves de manera

\footnotetext{
${ }^{66}$ http://www.worldbank.orglwbp/scapitaVtopid.
} 
efectiva y eficiente en el camino para el desarrollo.

Desarrollo urbano: Las áreas urbanas, con su anonimato y ritmo acelerado, pueden ser poco aptas para la cooperación social. Capital social y confianza son más difíciles de mantener y desarrollar en grandes grupos.

Abastecimiento de Agua \&: Saneamiento: El capital social contribuye a compartir informaciones sobre saneamiento y a la construcción de infra-estructura para la comunidad.

El concepto de capital social fue extraído de un marco teórico concreto, el individualismo metodológico, siendo posteriormente asociado a estudios sobre el norte de Italia, contrapuestos a la realidad del sur de ese país ${ }^{67}$. El concepto de "capital social" es básicamente una elaboración a partir de lo obvio: que una sociedad funciona mejor cuando sus miembros tienen confianza unos en los otros; que el asociativismo dentro de las estructuras horizontales así como la cooperación aumentan la información y las oportunidades sociales; que el respeto a los valores cívicos es un factor de desarrollo. El núcleo central del concepto de capital social enfatiza las formas de sociabilidad cotidiana y las orientaciones culturales en contraposición a las instituciones formales. Utilizado como instrumento de desarrollo económico, apunta a buscar (y a fortalecer) factores virtuosos fuera de las instituciones del Estado.

Transformado en un paradigma universal, disociado de los contextos e instituciones y de las complejas o variadas relaciones de confianza/ desconfianza, igualdad, jerarquía, solidaridad de grupo/desconfianza frente al otro, el concepto de capital social desconoce la rica experiencia de otras culturas, como la de los países asiáticos, donde los sistemas de relacionamiento jerárquico se mostraron altamente eficaces para promover el crecimiento económico y la igualdad social.

Los estudios sobre capital social presuponen que la afiliación a las organizaciones voluntarias constituye una medida universal del nivel de desarrollo de las relaciones horizontales de apertura y confianza entre los miembros de una comunidad. Se trata, sin embargo, de una medida que no considera las razones que pueden conducir a una persona a afiliarse a organizaciones voluntarias. Por ejemplo, en sociedades como la norteamericana, en la que las personas cambian constantemente de lugar de residencia, la afiliación a organizaciones voluntarias constituye un mecanismo para establecer relaciones sociales, lo cual no implica necesariamente niveles de confianza mayores a los registrados en comunidades con baja movilidad espacial, en que las personas no necesitan estar afiliadas a organizaciones formales para mantener altos niveles de confianza entre sí (por ejemplo, en el japón, en Suiza o en Alemania).

Toda sociedad se construye en torno tanto a valores de confianza y desconfianza, ambos

\footnotetext{
${ }^{67}$ Ver James Coleman, Fondations of Social Theory y Robert Putnam, Making Democracy Work.
} 
igualmente necesarios para una vida social, sustentada en padrones dependientes del funcionamiento efectivo de las instituciones $\mathrm{y}$, en última instancia, en la sanción pública. La paradoja es que la falta de confianza en el funcionamiento de las instituciones del estado a menu do favorece la valorización de las relaciones interpersonales, siendo por tanto fuente de capital social, mientras la confianza en el efectivo cumplimiento de la ley permite una baja intensidad subjetiva en las relaciones personales. En contextos de relaciones fundamentalmente anónimos, características de las sociedades contemporáneas, la confianza en los contratos se apoya en la certidumbre de que el cumplimiento es asegurado por las instituciones del estado y que los actos ilegales no permanecerán impunes. En suma, desde el punto de vista teórico y práctico, es imposible deslindar ias superposiciones entre las instituciones del estado y los padrones de conducta, entre confianza entre Ias personas y confianza en el orden publico. Si la utilización de conceptos sin demasiada densidad teórica no va más allá de un fiasco intelectual, la adopción de modelos de servicios públicos extraídos de otros contextos contiene peligros obvios. Pensar que best practices (casos de mejores practicas) y benchmarks (casos de mejores posiciones alcanzadas en un dado sector) pueden ser sustraídos del contexto societario origina rio y transferidos sin más a las realidades locales significa violentar el conocimiento sobre el funcionamiento de las sociedades adquirido durante un siglo por las ciencias sociales. Esto sin mencionar que los benchmarks y best practices en general son modelos altamente simplificados de experiencias complejas, algo así como similar de libros de auto-ayuda, pero para organizaciones.

Más allá de esa violencia intelectual, se trata de una violencia política, ya que los benchmarks son generalmente extraídoas del interior de una sociedad, la estadounidense, que presenta, entre los países desarrollados, altos niveles de desigualdad social así como los peores registros de eficiencia en sus sistemas de salud y de educación.

Tenemos, por cierto, un conocimiento sociológico precario sobre cómo funcionan las instituciones financieras internacionales, lo que hace que resulte dificultoso explicar este primitivismo intelectual. Sabemos que parte del problema se puede atribuir a la influencia política estadounidense, otra parte al hecho de que dichas instituciones son dirigidas por economistas, cuya sensibilidad sociológica es bastante limitada, pero gran parte de la cuestión debe ser adjudicada a una lógica de actuación global en que los conceptos y métodos revisten una aplicación universal. Con todo, al contrario de las lógicas de las empresas multinacionales, que procuran adaptarse a la realidad de los mercados locales bajo el riesgo de ver disminuir sus ventas, en el caso de las instituciones financieras internacionales los costos son absorbidos por los países receptores, que deben aceptar la imposición de las modalidades bajo las cuales podrán recibir financiamiento. Obviamente, esos modelos revelan cíclicamente su inadecuación, lo que a la postre determina que 
las instituciones internacionales encajonen sus "viejos" conceptos y creen otra moda, llamada a habilitar un nuevo ciclo de experiencias.

La tendencia a la generalización de modelos y a la homogeneización de las políticas públicas, promovida por las instituciones internacionales, sólo podrá ser corregida mediante el fortalecimiento del imaginario creativo de los partidos políticos y de la tecnocracia publica y el de sarrollo de sistema creativos de evaluación de la acción del estado y de sus relaciones con otros actores sociales (ONGs, empresas, poder local, universidad, etc.).

\section{La opinión pública global y los Estados Nacionales}

La formación de una opinión global remite a un proceso de larga duración. Desde sus orígenes, en el siglo XVIII, la opinión pública fue un fenómeno transnacional, intra-europeo, con repercusiones en las elites de las colonias. En los siglos XIX y XX, la opinión pública internacional se construyó a partir de las grandes ideologías políticas - liberalismo, nacionalismo, socialismo y comunismo -, canalizadas fundamentalmente por partidos políticos, que eran sus principales vectores de difusión. Por cierto que junto a las estructuras partidarias deben contabilizarse otros movimientos sociales importantes, como fue, en su época, por ejemplo la lucha feminista por el sufragio universal.

Mientras la antigua opinión pública nacional, asociada a los partidos políticos, se expresaba a través de proyectos dotados de propuestas de organización de la sociedad y del Estado nacional, la nueva opinión pública, asociada a la llamada "sociedad civil", se organiza en torno a reivindicaciones al Estado, centradas en temas específicos, generalmente movilizadas a partir de eventos con repercusión mediática. Mientras la antigua opinión pública, constitui da sobre la base de ideologías políticas, reivindicaba el poder y/o la transformación del estado, la opinión pública asociada a la "sociedad civil" se organiza a partir de movilizaciones contra el Estado o de demandas al Estado. Si, por un lado, la nueva opinión pública posee la capacidad de reformar ciertas prácticas del poder público, por otro laso, ella desarrolla un discurso con potencial de despolitizar los ciudadanos y de deslegitimar las instituciones políticas.

La ideología de los derechos humanos disocia lo social del Estado y de la nación, mientras que las nuevas luchas sociales centradas en reivindicaciones de derechos deslegitiman la noción de interés. Sin embargo, las relaciones internacionales continúan estructuradas en torno a Ia noción de intereses nacionales y a la disposición de los Estados a defenderlos ${ }^{68}$.

El Estado continúa manteniendo una legitimidad operacional — es decir, aún se espera de él

\footnotetext{
${ }^{68}$ Incluso mediante la guerra-, teniendo como base la disposición de la opinión pública a aceptar que las ciudadanos "mueran por la patria", esta es, por la representación de un interés colectivo.
} 
que asegure el orden, los servi cios públicos y el crecimiento económico - , pero ha perdido su aureola de legitimidad trascendental, asociada históricamente a su papel de representante de la patria y de la nación, que ya no disfrutan de gran parte de su poder discursivo movilizador. La profesionalización de los ejércitos, verificada prácticamente en todos los - países desarrollados así como el fin de la conscripción obligatoria son los síntomas más obvios del final de un período histórico.

Los derechos humanos y la democracia, o sea, el uso de la negociación como mecanismo de creación de consenso, sólo pueden ser plenamente efectivos al interior de una sociedad democrática, mientras que, en el plano internacional, la lucha por los derechos humanos y por la democracia conviven con realidades que exigen la defensa pragmática de los intereses nacionales.

En los países desarrollados, esa doble realidad de vida política nacional e internacional se expresó históricamente en la convivencia de la democracia en el plano interno con el nacionalismo en el plano externo. En la medida en que el nacionalismo dejó de ser una fuerza motora, la capacidad de los Estados nacionales para actuar de forma efectiva, incluso empleando la fuerza militar, hoy tiende a debilitarse. La "desvinculación" del Estado nacional de la capacidad movilizadora nacionalista es particularmente relevante en los países en los que la fuerza económica podría tener una proyección militar (como japón o la Unión Europea).

Los procesos de desinstitucionalización - conforme alos cuales el Estado pierde su carácter de representante del interés general, capaz de unir a la población en tomo a valores e intereses de la patria y la nación, anteriormente vividos como sagrados y por los cuales se justificaba luchar y morir - están particularmente avanzados en Europa y japón, influenciados por la experiencia traumática de la Segunda Guerra Mundial y de las guerras coloniales.

La construcción europea implicó el abandono de nacionalismos así como de Ia referencia a una historia de guerras que ya no pueden ser presentadas como experiencias gloriosas, pues los enemigos de otrora son los conciudadanos de hoy. No es casual que en la Unión Europea sea el Reino Unido - país que saliera de la Segunda Guerra Mundial con su auto estima nacional reforzada - el que mantiene mayor capacidad militar y un fuerte sentimiento de soberanía nacional. La estrategia francesa, por su parte, ha evidenciado una constante ambigüedad. Desde las guerras napoleónicas, Francia ha vivido una declinación relativa en el concierto internacional en virtud de la pérdida de su peso demográfico yeconómico siendo que después de la segunda guerra mundial procuró una alianza privilegiada con Alemania y buscó afirmar su posición a través del fortalecimiento de Europa, intentando mantener su lugar como nación protagónica. Tal estrategia supone la capacidad de controlar o de liderar la Unión Europea, lo cual es algo cada vez más difícil pues dicha unión está compuesta por 26 naciones bastante dispares. 
La formación del mercado único europeo se construyó en torno a la ideologia de los derechos humanos y del debilitamiento de los nacionalismos o de la soberania nacional. Asi la Unión Europea pasa por enormes dificultades para crear una voluntad política que vaya más allá de los intereses económicos. La parálisis de la voluntad geopolitica que produce esa situación se expresó en la crisis de Yugoslavia, cuando un genocidio en las fronteras de la Unión Europea fue enfrentado recién al entrar en escena la voluntad de los Estados Unidos, que, a través de la OTAN, impuso una intervención militar, fuera del marco de las Naciones Unidas ${ }^{69}$.

Paradójicamente, las chances de un mundo multipolar, principal base para fundar una política internacional multilateral y responsable de una agenda que sustente nuevas formas de gobernanza internacional de carácter más democrático, son reducidas en función de la acción de la "sociedad civil" que, al movilizar la bandera de los derechos humanos, debilita la capacidad de los Estados para justificar el uso de la fuerza militar.

\footnotetext{
${ }^{69}$ Para una comparación entre Europa y las Estados Unidos, a partir de una perspectiva crítica de la posición europea, ver Robert Kagan, Of Paradise and Power.
} 


\section{Capitulo IV}

\section{Transformaciones sociales y juridicionalización del conflicto social en América Latina}

El ejercicio del poder es la capacidad de controlar las fuentes de incertidumbre y de transferir el costo de lo imprevisible hacia otros individuos/grupos sociales. La revolución del derecho moderno consistió en imponer a los grupos dominantes la incertidumbre jurídica, esto es, una forma de distribución de la justicia inmune a la transferencia de poderes económicos o políticos, forzándolos a aceptar una situación de igualdad y de incertidumbre ante el proceso judicial. Para asegurar su carácter universal, la ley, en la visión liberal, debe tratar a todos los sujetos de la misma forma, es decir, no puede permitir que el acceso desigual a recursos de poder de otras esferas (económica, política, cultural) invada la esfera del poder jurídico ${ }^{70}$. Como vimos, la igualdad ante la ley fue perfeccionada a medida que fueron creándose mecanismos compensatorios para las relaciones contractuales entre partes provistas de un poder desigual de negociación.

El debate sobre la ciudadanía en América Latina nos remite a una cuestión que se encuentra en el corazón de la idea de los derechosciudadanos: la capacidad del Estado de proteger a los ciudadanos. La protección tiene un doble sentido: para ser protegido, el individuo tiene que cumplir una serie de obligaciones hacia la comunidad, como su participación en la vida pública o en la defensa de la nación. La consolidación de muchos derechos en Europa y en Estados Unidos como consecuencia de la participación de los sectores populares en guerras patrióticas confirma un tópico central de las relaciones entre el Estado y la sociedad, a saber: la exigencia de participación de los individuos en la protección del estado es recompensada con la protección del individuo por el Estado.

La juridicionalización del conflicto social en América Latina, más allá de los procesos indicados, fue radicalizada por la convergencia de cuatro factores específicos:

1) Las nuevas constituciones, posteriores al ciclo de las dictaduras de los aflos 70 y 80 , fortalecieron el papel de las cortes constitucionales, crearon nuevas instancias de defensa del derecho de ciudadanía y ampliaron los derechos asegurados por la constitución ${ }^{71}$.

2) El carácter coyuntural de las leyes, en función del imperativo económico de lucha contra la inflación y de estabilización monetaria, implicó una ruptura de los contratos por parte del Estado

\footnotetext{
${ }^{70}$ Ver Michael Walzer, Spheres of Justice

${ }^{71}$ Para una visión optimista de los procesos de juridicionalización de la sociedad brasileira, ver Luiz Werneck Vianna et al., Corpo e alma da magistratura brasileira. Una visión crítica del sistema de control constitucional es presentada por Rogério Bastos Arantes en judiciário e política no Brasil.
} 
(trayendo aparejado una inflación de leyes), al tiempo que colocó alos ciudadanos y a las empresas contra los Poderes Legislativo y Ejecutivo, transformando al Poder Judicial en árbitro del conflicto social.

3) Paradójicamente, la juridicionalización del conflicto social se ha venido desarrollando en un momento en que una parte significativa de la población trabajadora del continente vive un sentimiento de pérdida de derechos (tanto laborales como de previsión social). Esa pérdida de derechos -sin duda real- fue acompaflada por una expansión de derechos en otras áreas (como, por ejemplo, en el plano de la mujer, de la infancia, de la cultura o la ecología). Así, tenemos en parte una pérdida de derechos (algunos de los cuales contenían privilegios corporativos), pero también tenemos un dislocamiento de derechos, en un juego no necesariamente de suma cero. Como ya vimos, la creación de nuevos derechos derribó la noción tradicional de desigualdad social, sustentada en una visión unitaria de la sociedado

4) En América Latina, si bien la práctica de la impunidad, más concretamente, el hecho de hacer valer en el campo jurídico el poder emanado de otras esferas de poder (político, económico), pone en duda la universalidad del sistema jurídico.

La juridicionalización del conflicto en América Latina no puede ser evaluada unilateralmente sea como un proceso virtuoso o como algo negativo. Ella es más bien una expresión de la democratización de la sociedad y ocupa el lugar dejado por las instituciones políticas, incapaces de generar respuestas y visiones de futuro que organicen el conflicto social dentro del cuadro político-partidario.

Como vimos, la juridicionalización del conflicto social tiene una limitada eficacia como instrumento de disminución de la desigualdad social, pues delimita la representación de intereses a determinados nichos sociales, sin una visión de conjunto de la sociedad, fragilizando la política partidaria, de alguna manera sustituida por la producción de "utopías parroquiales", por nuevos actores cuyas reivindicaciones tienen, en general, un impacto más simbólico que práctico.

La distancia -que para algunos significa un verdadero abismo- entre el mundo de las leyes y la realidad social, parece entonces restablecer en nuevos términos la vieja dicotomía, enunciada por el político e intelectual argentino Domingo Faustino Sarmiento, según la cual, América Latina estaría condenada a oscilar entre la civilización y la barbarie, entre los valores europeos y la realidad social de masas del continente, entre constituciones liberales y pueblos incapaces de ejercer la democracia (producto, según algunos, de la hostilidad de la vida de las pampas, de la exuberancia de los bosques tropicales o de la opresión a que fueran condenados 
los indígenas o los esclavos, entre otras causas). ${ }^{72}$

La versión contemporánea "progresista" de este enfoque considera que la barbarie sería generada más por la "falta de preparación" del pueblo que por la exclusión social asociada al modelo neoliberal. En principio, los actores colectivos y los movimientos sociales populares serían esencialmente virtuosos, pero las políticas impuestas por las agencias intemacionales, al servicio de determinado modelo de globalización, producirían pobreza, miseria, exclusión social y el crecimiento de la desigualdad social, atentando, en definitiva, contra el funcionamiento de la democracia y generando un potencial de violencia individual y/o colectiva.

Las sociedades latino americanas contemporáneas, sin embargo, han cambiado profundamente, y la visión dicotómica, tendi ente a oponer un mundo social "real" a un mundo jurídico "formal", ha perdido vigencia, como también se ha visto devaluada la visión de una realidad "profunda" y virtuosa, cuyo potencial de realizaciones se vería obstaculizado por la acción de factores extemos ${ }^{73}$.

Desde el momento en que la oposición entre lo real y lo formal dejo de servir como parámetro para entender donde estamos y lo que nos falta para llegar al "punto ideal" — conforme a un paradigma que permitía al sociólogo mostrar la verdadera fase de la sociedad mientras el jurista "positivista" parecía vivir en un castillo sin cimientos sociales- debemos elaborar nuevos modelos de dinámica social que expliquen cómo, pese a que la nueva sociabilidad latinoamericana haya integrado valores igualitarios e individualizantes, ellos no tengan mayor impacto en la disminución de la desigualdad social y la violencia. Así, en vez de acudir a nuevas versiones de la antigua dicotomía entre el mundo jurídico formal y el mundo social real, se trata de desarmar y explicar la paradoja de una sociedad que se desea igualitaria, que reivindica valores liberales y de justicia social, identificándose fuertemente con ellos, pero que continúa generando desigualdades y transgresiones a las normas de convivencia social.

\section{Ciudadania en América Latina: variaciones de la modernidad}

Como vimos en el primer capítulo, la ciudadanía se constituyó en el marco de comunidades nacionales, a partir de valores compartidos, sedimentados a través de la historia de construcción de la nación y referidos, en general, a un mito de origen. La ciudadanía en América latina fue de alguna manera condenada a ser vivida, por cierto bajo las características cambiantes de cada país y

\footnotetext{
${ }^{72}$ Sobre la representación de la historia de Argentina a partir de la obra de Sarmiento, ver Maristella Svampa, El dilema argentino.

${ }^{73}$ La relación paradojal entre democracia y el aumento de la violencia en Brasil es analizada por Angelina Peralva en Violência e democracia.
} 
de cada época, a partir de una oscilación entre la idea de una ciudadanía y una sociedad deseables, de acuerdo a un modelo extranjero, y la búsqueda de una cultura nacional auténtica, a partir de la cual construir una forma de ser propia del colectivo social.

Europa - en mayor medida que los Estados Unidos, por lo menos hasta la segunda mitad del siglo XX - para las elites de América latina fue la principal fuente de inspiración, desde las luchas por la independencia, de los modelos de sociedad que deseable. Las elites se imaginaban a sí mismas viviendo en las sociedades europeas y aspiraban a reproducir en sus países la imagen que tenían de aquellas sociedades. Pero, como sabemos, las enormes diferencias sociales construidas a base de siglos de explotación colonial generó un foso social y cultural entre el pueblo y las elites.

Alcanzar la modernidad significaba, para esas elites, olvidar el pasado indígena o africano y reconstruirlIa comunidad nacional a partir de las ideas europeas ${ }^{74}$. Por cierto, los partidos socialistas y comunistas no modificaron la tendencia a la desvalorización del pasado y a apostar todo al futuro, acudiendo a un discurso en el que la cultura popular debía ser depurada de sus elementos "mistificadores", en particular, de la religión ${ }^{75}$.

Periódicamente se llevaron a cabo en América Latina variados esfuerzos de recuperación del mundo reprimido, así como intentos por repensar la nación a partir de la integración de las culturas de los pueblos oprimidos. Dicha recuperación encontró en el indigenismo hispanoamericano de inicios del siglo XX, su primera expresión importante mientras que el impacto cultural más amplio haya estado asociado a la Revolución Mexicana y a sus diversas manifestaciones artísticas, teorizadas por José Vasconcellos en torno de la idea de una nueva "raza universal".

Pero tales esfuerzos, renovados por los nacionalismo, a veces de inspiración neofascista, como el movimiento Integralista en Brasil, o el revisionismo histórico peronista, no llegaron a modificar las expectativas miméticas depositadas en los países centrales. A partir de los afios 50, en particular de los procesos de urbanización, la tendencia a la identificación con las sociedades desarrolladas se expandió a toda la sociedad. Así, la mayoría de los sectores sociales pasaron a compartir el deseo de querer ser modernos, de ser igual a los países desarrollados, en cualquiera de las versiones o modelos ofrecidos en la época (liberales, socialdemócratas o comunistas).

La vocación imitativa difiere según el país o el momento histórico, de Ia misma manera que la insatisfacción con "lo que somos y por qué somos" tendió a cambiar de foco. Desde la insatisfacción con el "primitivismo" del pueblo -característica de las elites latinoamericanas de la

\footnotetext{
${ }^{74}$ La división esquizofrénica de la elite política latinoamericana, cuya identificación con la cultura europea circulá por andariveles separados de sus brutales prácticas represivas, fue retratada en forma magistral por la literatura, en particular, por El siglo de las luces, de Alejo Carpentier, y por Yo el supremo, de Augusto Roa Bastos.

${ }_{75}$ Ciertos autores marxistas, como el peruano Mariátegui, en los anos 30 fueron a buscar en la experiencia inca la fuente de inspiracián de un comunismo primitivo, pero sin mayores consecuencias para la teoria marxista o para el socialismo latinoamericano.
} 
segunda mitad del siglo XIX, cristalizada en la obra Civilización y Barbarie de Sarmiento - a la insatisfacción con la desigualdad social contemporánea, se fue pasando por un largo proceso de integración de los diversos sectores sociales tanto al sistema político y cultural como al trayecto de construcción del Estado nacional. En ese espacio de insatisfacción, entre lo que somos y lo que desearíamos ser; se instaló la hipertrofia de las expectativas salvadoras de cada nuevo gobierno y el sentimiento de vi vir en una sociedad siempre situada más acá de nuestros deseos.

La constante inclinación a reflejarse en los países avanzados se hizo sentir incluso a nivel de la propia ciencia social, dividida entre una tendencia dominante, inspirada en los autores clásicos del pensamiento social, basados en la experiencia histórica de sus propios países, y una verti ente dispuesta a reconocer en las culturas nacionales sus singulares trazos civilizatorios, no deducibles de una teoría general de la modernización ${ }^{76}$.

La inclinación a reflejarse en la experiencia de los países capitalistas centrales, empleando un prisma idealizante, llevó a distorsionar esa misma experiencia. Eso explica las diferentes visiones de la modernidad sostenidas por la teoría social en América Latina y en Europa. Como indica Martuccelli, en la teoría social clásica la experiencia moderna es vista como una experiencia trágica: la de una condición humana que perdió sus referencias en el mundo junto con los sustentos proporcionados por la fe y la tradición. En la teoría social latinoamericana, en cambio, la modernidad aparece como un ideal a ser alcanzado mientras que la modernización es vista como un camino para alcanzar una mayor armonía y felicidad. En otros términos: en Europa, lo trágico es ser moderno; en América Latina lo trágico es pensar que no conseguimos ser modernos.

En definitiva, los estudios sobre ciudadanía en América Latina están permeados por la visión idealizante de la experiencia moderna y por una mirada que se autodefine por la imagen construida de lo que debe ser la ciudadanía. Aún las versiones más elaboradas de la ciudadanía no consiguen liberarse de esa visión. Consideremos, por ejemplo, el concepto de "ciudadanía regulada" de Wanderley Guilherme dos Santos, según el cual las raíces de la ciudadanía "se encuentran, no en un código de valores políticos, sino en un sistema de estratificación ocupacional [...] definido por una norma legal"77.

El fenómeno central que refiere Wanderley Guilherme dos Santos es el papel fundamental jugado en Brasil durante décadas por la Cedula de Trabajo como mecanismo de acceso alos derechos sociales y como instrumento de reconocimiento simbólico y práctico. El concepto de ciudadanía regulada es construido en contraposición al de ciudadanía "política", de alcances

\footnotetext{
${ }^{76}$ Ver Bemardo Sorj, A construção intelectual do Brasil contemporâneo, segunda parte; Sérgio Costa, As cores de Ercília; José Mauricio Domínguez, "A dialéctica da modemizaçao conservadora e a nova história do Brasil"; e Jessé Souza (org.), O malandro e o protestante.

77 Ver Wanderley Guilherme dos Santos, Cidadania e justicia, p. 75.
} 
universalistas. Ahora bien, la ciudadanía en sus diversas experiencias históricas, pasó por prácticas de regulación fundadas en formas de estratificación social legalmente sancionadas. En la mayoría de los países europeos la ciudadanía fue inicialmente censitaria, esto es, el voto estaba asociado a la propiedad y a la renta. En algunos casos, el factor de exclusión fue la religión, en otros, el género (es impresionante descubrir cuán recientemente las mujeres tuvieron acceso al voto en los países avanzados), cuando no la raza (baste senalar que en los Estados Unidos, hasta hace pocas décadas la segregación racial tenía estatuto legal).

En lo que hace alos derechos sociales, sólo después de la posguerra ellos llegaron a tener en Europa un alcance hasta cierto punto universal. La Cedula de Trabajo fue una invención de la Revolución Francesa, reapropiada luego por el fascismo, mientras que en la Europa de la primera mitad del siglo XX, la distribución de los derechos sociales entre el campo y la ciudad siempre fue desigual, como también lo fue entre los diferentes sectores de trabajadores, sin mencionar el gran número de "indocumentados" que en Europa y en Estados Unidos hoy trabajan sin acceso alos derechos sociales y con miedo de ser extraditados en cualquier momento.

En consecuencia, la cuestión no es tratar la experiencia brasilena como un caso de ciudadanía regulada frente a un modelo de ciudadanía normal, universalista, sino más bien reconstruir el propio concepto de ciudadanía a partir de la experiencia brasilena, como una de las variantes posibles del problema universal de regulación de la ciudadanía, esto es, de los ritmos diferenciales y de los criterios diversos que llevan a varios sectores de la población a usufructuar de los derechos-ciudadanos.

Marcelo Neves, autor que presenta trabajos originales de sociología jurídica, también cae en una tendencia a construir oposiciones frontales entre países centrales y países periféricos, cuando de lo que se trata es más bien de una graduación o de una diferencia de grado. En sus últimos trabajos, se nota una profundización de la tendencia a generalizar excesivamente la experiencia brasilena o a trasladarIa al conjunto de los países "de la periferia del sistema mundial contemporáneo"78. Partiendo del modelo luhmanniano, conforme al cual el sistema jurídico presenta un cierre operacional, fundado en la oposición legal/ilegal, Neves argumenta que los países periféricos no logran mantener la autonomía del sistema jurídico en la medida en que és te es invadido por otros códigos sociales. Así, principios de orientación de conducta como poder/no poder o amigo/enemigo terminan colonizando el campo jurídico, no permitiendo su funcionamiento como subsistem a autónomo y destruyendo los mecanismos internos de auto-reproducción del sistema judicial. La consecuencia de todo esto es una práctica social que promueve la intervención constante en el

78 Ver Marcelo Neves, “Et si le deuzième chameau venalt à manquer?”. 
proceso jurídico de elementos extra fios al sistema autoreferencial, susceptibles de usurpar el lugar de la legalidad y de los principios constitucionales.

Para Neves la invasión constante de intereses privados en el sistema judicial conduce a la inconsistencia jurídica y a la destrucción de las relaciones de continuidad entre regla y decisión jurídica, no permitiendo, en suma, la consolidación del subsistema jurídico, constantemente desestabilizado por la penetración de fuerzas externas, en particular, por el poder del dinero y la política, lo cual alienta la producción caótica de normas y regulaciones no contempladas en los textos jurídicos. En ese contexto, el papel de la Constitución como domesticadora de la política pierde eficacia, transformándose más bien en un sistema simbólico desprovisto de consecuencias normativas, utilizado de forma aleatoria para legitimar medidas ad hoc. Así, pues, la sociabilidad del mundo pos-tradicional en los países periféricos estaría condenada a un alto grado de imprevisivilidad, ya que se encontraría en un contexto de "inseguridad jurídica incontrolable"79.

Paradójicamente, el texto de Neves comenta un trabajo póstumo de Luhmann ${ }^{80}$, en el que és te reconoce la existencia de una tendencia creciente en los países avanzados a sabotear los códigos que orientan los diversos subsistemas sociales, inclusive el jurídico. La invasión cada vez mayor del sistema jurídico por el poder económico no es, por tanto, un privilegio de los países periféricos, como no lo es tampoco la tendencia a la privatización de los sistemas de seguridad o la transferencia a manos privadas del uso de la fuerza fuera de los marcos de controllegal.

La imagen de un Poder Judicial bloqueado, tal como lo percibe Marcelo Neves, tomada literalmente, nos coloca ante sociedades caóticas, incapaces de hacer funcionar el propio mercado capitalista. Pero no es este el caso. En las sociedades periféricas - sin olvidar la enorme variedad de si tu aciones nacionales- si bien los subsistem as sociales presentan grandes fragilidades y problemas, no dejan por ello de funcionar. Más bien lo que observamos son graduaciones en lugar de oposiciones que llevan a idealizar una de las partes y a demonizar a la otra. El análisis de la experiencia histórica revelaría, en todo caso, un constante movimiento de invasión de los subsistemas sociales y de reacción contra tal invasión ${ }^{81}$, lo cual rige igualmente para los países centrales. El caso italiano es un ejemplo revelador de un sistema político con partidos corruptos, cuestionado por la Operación Manos Limpias, a la cualle siguió una contra-reacción de los grupos afectados.

\footnotetext{
${ }^{79}$ Ibid, p. 118.

${ }^{80}$ Ver Niklas Luhmann, "La restitución de douiziéme chameau".

${ }^{81}$ Como lo muestra Albert Hirschman en Saída, voz e lealdade.
} 


\section{Individualismo a la latinoamericana}

De acuerdo a la dinámica de la modernidad, las personas se individualizan y la sociedad se complejiza, al tiempo que se entrelazan cada vez más los destinos individuales y sociales, exigiendo una creciente intervención del Estado. El programa mínimo liberal, conforme al cual el Estado debe limítarse a proteger las libertades individuales, siempre fue una quimera y hoy no tiene mayor relevancia frente a la intensificación de la complejidad de las sociedades modernas. La defensa de la moneda y las políticas de intervención en el ciclo económico, la oferta y la regulación de los servicios públicos, el control de calidad, la normalización técnica, la investigación científica fundamental, constituyen actividades, entre muchas otras, integradas al repertorio del Estado moderno, que ninguna ideología política contemporánea hoy cuestiona. Lo que sí se cuestiona, en todo caso, es lo que debe ser protegido o regulado, cómo y de qué forma.

Pero pese a todo, el sentimiento del individuo contemporáneo es de creciente abandono, incertidumbre y desprotección. ${ }^{82}$ Tradicionalmente, la protección era asegurada por sistemas de dominación o de subordinación a dispositivos político-religiosos, llamados a ofrecer una compensación simbólica y una resignación ante el sufrimiento, ante lo arbitrario o las incertidumbres de la vida terrena. En las sociedades contemporáneas, la representación y la práctica de la protección fueron transformadas por la acción de tres procesos correlacionados: a) la erosión de las referencias religiosas y la consiguiente dilución de los valores absolutos de las grandes ideologías de la modernidad, fuente de debilitamiento de los sentimientos de seguridad ontológica; b) la individualización creciente, ligada a la crisis de los sistemas tradicionales de dominación tendientes a asegurar mecanismos de seguridad ciertamente opresivos (como el casamiento bajo dominación masculina, el trabajo bajo explotación patronal, la filiación con dominación paternal); y c) las transformaciones tecnológicas y la globalización de los procesos sociales, proclives a aumentar la sensación de impotencia e incertidumbre respecto al futuro.

En el vacío social y existencial producido por la modernidad contemporánea, los individuos se ven condenados a la incertidumbre y a la desprotección existencial. Si bien los individuos pueden tejer en todo momento nuevos lazos de solidaridad - en la amistad, en la familia o en el amor (quimera moderna por la cual se espera alcanzar certezas absolutas, la trascendencia proveniente de una fusión de identidades, el encantamiento del mundo y una protección práctica) —, pueden buscar ganar dinero, experimentar religiones o buscar el apoyo de especialistas (psicólogos de la mas variadas tendencias), no pueden prescindir del Estado para asegurar un mínimo de seguridad frente

\footnotetext{
${ }^{82}$ La distancia entre el individuo alslado y un Estado cada vez más poderoso produjo una enorme bibliografia, a partir, en particular, de las investigaciones sobre el origen del totalitarismo. Ver sobre el tema el clásico trabajo de Erich Fromm, Escape from Freedom.
} 
a la inestabilidad del mercado de trabajo y de la vejez, frente al costo creciente de la salud y la educación, ante el poder de las grandes empresas, el caos urbano o la deterioración del medio ambiente. Incluso el tema de la violencia, en apariencia monopolio de los países periféricos, se ha vuelto un problema relevante en la agenda política de los países centrales.

Cada sociedad nacional presenta sus propios sistemas de protección del ciudadano, dotados de características propias, historica mente perfiladas. De todas maneras, como ya indicamos, la crisis del Estado de bienestar social no ha significado una disminución de la centralidad del Estado en las sociedades modernas de este nuevo milenio.

En América Latina, la protección estatal se desarrolló de manera bastante diferente. En términos generales, el primer eje de integración ciudadana giró en torno a la oposición campociudad. Hasta los años 60, en la mayoría de los países del continente, la población rural permaneció al margen de las políticas sociales, padeciendo un limitado, cuando no inexistente, acceso a las instituciones de la ciudadanía civil y política. En el medio urbano, la protección del Estado tendió a polarizarse entre sectores sociales que usufructuaban de los servicios públicos y segmentos de la población que permanecían en la periferia de la distribución de la riqueza canalizada por el Estado.

El acceso alos bienes distribuidos por el Estado estuvo pautado, en general, por un fuerte componente patrimonialista o corporativista ${ }^{83}$. Las clases dominantes, gracias a la influencia de su poder político y económico, mantuvieron cierta impunidad frente a la ley y tendieron a ver al Estado como a un botín, como a un despojo a ser asaltado. A medida que el Estado se fue modernizando, integró en sus aparatos y en las empresas públicas a sectores de clase media que pasaron a adquirir una serie de derechos sociales, que asociados a un fuerte corporativismo, les permitió disfrutar de ciertos derechos/privilegios frente al resto de la población y consumir gran parte de los gastos sociales del presupuesto nacional. Finalmente, los segmentos asalariados, en particular los encuadrados en las empresas de gran tamafio, fueron integrados a las políticas públicas, ya sea directamente, a través de beneficios sociales, ya sea indirectamente, mediante acuerdos laborales que permitieron el acceso alos servicios ofrecidos por las empresas estatales. El resto de la población urbana y rural permaneció excluido de los recursos públicos del Estado, siendo así percibido por este segmento social con un rostro más bien represor o al servicio de los grupos dominantes.

Con todo, tal visión debe ser matizada. Países como Argentina, Uruguay, Costa Rica y en menor medida Chile - cuyas poblaciones estuvieron constituidas mayoritariamente por inmigrantes europeos, sin pasado esclavista ni relaciones de sometimiento servil de las poblaciones

\footnotetext{
${ }^{83}$ Ver Bernardo Sorj, A nova sociedade brasileira.
} 
rurales indígenas - se urbanizaron precozmente, integraron gran parte de la población al sistema salarial formal y garantizaron el acceso alos servicios públicos urbanos así como a Ia educación básica. Argentina, Uruguay, Costa Rica, y en menor medida Chile, alcanzaron a desarrollar, ya a mediados del siglo XX, una estructura social con una sólida clase media y menores niveles de desigualdad social que los del resto del continente.

En la América latina contemporánea la ampliación del Estado tuvo una doble característica: por un lado expandió los instrumentos de intervención racional en la economía - modernizando parte de sus aparatos, incrementando su participación en la actividad productiva, en la creación de infra-estructura y de un sistema educacional, científico y tecnológico - ; por otro lado, mantuvo una enorme permeabilidad a la colonización interna por parte de los grupos dominantes. ${ }^{84}$

En las últimas décadas, la creciente democratización de la cultura y de las expectativas sociales, las transformaciones económicas, la disminución del peso social y político de la clase obrera industrial y las presiones del sistema financiero internacional en el contexto de políticas antiinflacionarias orientadas a una mayor austeridad fiscal, llevaron a una implosión del modelo tradicional de colonización del Estado por los grupos dominantes y por las clases medias.

La disolución de los antiguos vínculos clientelísticos, así como el fin de las formas tradicionales de dominación en las modernas sociedades urbanas de América Latina, no implica necesariamente el surgimiento de un individualismo ajustado a los valores de respeto a la cosa pública, de esfuerzo personal y de trabajo, como suponían las teorías clásicas de la modernización. Dicho de otro modo, el vacío dejado por la desaparición de las antiguas lealtades y de los sistemas jerárquicos no está llamado a producir automáticamente una sociedad liberal. Aun cuando sea posible identificar en el individualismo dominante en Américá Latina muchas de las características descriptas por la bibliografía sociológica acumulada en los países centrales, el mismo presenta ciertas especificidades resultantes del cuadro cultural e institucional local. De manera sumaria y teniendo como referencia, en particular, la situación brasilefia, indicamos a continuación algunos trazos específicos de los procesos de individualización en el continente:

1) La primera característica es la hiper-reflexibilidad. Mientras en los países centrales el campo de la reflexibilidad y, por extensión, de incertidumbre en las relaciones sociales, es vivido en el ámbito de las orientaciones intersubjetivas privadas o del mercado, el individuo latinoamericano debe orientar su acción suponiendo la incertidumbre, incluso en la interacción con las instituciones del Estado. O sea, el mundo institucional público está incluido en el ámbito de la acción reflexiva y de incertidumbre. Así, por ejemplo, frente al policía que le está poniendo una multa, el ciudadano

\footnotetext{
${ }^{84}$ Ver ibid, cap. 1.
} 
puede decidir pagarla o intentar corromperlo; ante una fiscalización impositiva, deberá evaluar si vale la pena pagar los impuestos o dar propina al fiscal; en el caso de que sea robado, el ciudadano deberá evaluar si debe o no presentar la denuncia en la policía, pues ello puede atraer la atención de ladrones o secuestradores asociados a las "fuerzas del orden"; deberá ponderar también si vale la pena llevar adelante un litigio jurídico, considerando que la otra parte podrá anteponer su poder económico en el sistema judicial; y si desarrolla actividades económicas, en fin, podrá realizarlas al margen de los controles públicos o no, enfrentando cada reglamentación estatal o cada ley teniendo en cuenta la posibilidad de escapar a la norma legal ${ }^{85}$.

2) La segunda característica es que se trata de una sociabilidad que amalgama el individualismo con la desigualdad social, alimentando la desresponsabilización hacia el espacio público. Junto con los nuevos mecanismos de dominación anónima, aún persisten formas de dominación ligadas a relaciones de poder personal, lo cual significa, para los grupos poderosos (concepto genérico en el que puede incluirse, según el contexto, la polida) la posibilidad de imponer su voluntad sin contemplar las prescripciones legales, y para los grupos populares, la aceptación de situaciones de sumisión y de pérdida de autonomía. En ambos casos, se fomenta la irresponsabilidad: en el grupo dominante, al incentivar su impunidad, y en el grupo dominado, al estimular su auto-representación como víctima. Si la desigualdad social informa y transforma los procesos de individualización en todas las sociedades modernas, en los países periféricos la situación es más fácilmente discernible habida cuenta de los extremos de desigualdad social. Un caso paradigmático reside, por ejemplo, en la presencia de la empleada doméstica en las relaciones familiares, presencia que reorganiza las posiciones relativas al interior de la familia y produce relaciones tanto de explotación como de sumisión dentro del género femenino ${ }^{86}$.

El hecho de que la mayoría de las feministas en América latina hayan general mente dejado de lado, en sus elaboraciones teóricas y en sus investigaciones, la centralidad del trabajo doméstico en la constitución de relaciones de género y de familia, indica los límites de la transferencia de los marcos teóricos y de las luchas por los derechos elaborados en los países centrales.

3) En tercer lugar en América latina, el "presentismo" individualista de la condición moderna, esto es, la acción orientada a una gratificación inmediata y la pérdida del sentido de la historia como una construcción colectiva dotada de un pasado y un futuro común, no elimina el "futurismo" colectivo, la esperanza de que "algo" o "alguien" tralga una respuesta a los problemas

85 Obviamente, esta situación no es monopolio de los países periféricos. En los países centrales, el universalismo nunca es total; en particular los grupos dominantes nunca dejan de utilizar su influencia para obtener una mayor impunidad. 86 Lo que no significa, obviamente, que los hombres no se beneficien igualmente con los servicios de la empleada doméstica. Con todo, como un indicio actual de la mayor individuación de los sectores populares y de transformación de los padrones sexuales de las clases medias, baste seiialar, en el caso brasileiro, la cuasi desaparición de la tradicional práctica de iniciación sexual de los adolescentes con las empleadas domésticas. 
de la sociedad. Lo cual se expresa en la hipertrofia de expectativas depositadas en el mundo de la política, en el riesgo continuo de desbordamiento del sistema institucional dadas las expectativas sociales puestas en un "salvador de la patria" y en el sentimiento de refundación de la nación que acompafia cada nueva elección ${ }^{87}$.

4) en cuarto lugar se profundiza el defasaje entre la referencia internacional y la realidad nacional. Como vimos, las elites latino americanas y, en las últimas décadas, las clases medias, vivieron la realidad nacional a través del espejo y la comparación con los países centrales o, en la tradición de izquierda, con los países comunistas. El proceso de globalización de las comunicaciones -a través del acceso generalizado a la radio y a la televisión — trajo aparejado una democratización de las expectativas así como la extensión a prácticamente toda la población del sentimiento de privación relativa, producto de la comparación de la realidad personal y nacional con la de los países más avanzados.

5) En quinto lugar la limitada autonomía de los subsistem as sociales determina la centralidad de las redes personales a la hora de movilizar apoyos frente a situaciones de arbitrio institucional, la permanencia de relaciones de dependencia personal construidas en torno a la desigualdad económica y el sentimiento de formar parte de una sociedad por default, esto es, de compartir un conjunto enmarafiado de problemas (violencia, desigualdad, corrupción), limitan los procesos de alienación social en el sentido de disminuir las tendencias al distanciamiento, característico de la sociedad moderna, entre el individuo, la sociedad y la cultura. En otros términos, la fuerte interpenetración de los subsistemas sociales y el sentimiento de "caos" societario afectan la autonomización de los individuos, limitando también la inmersión en una subjetividad personal trágica, alslada del mundo ${ }^{88}$.

\footnotetext{
${ }^{87}$ Para Giorgio Alberti, el rasgo característico de la política latinoamericana, que él denomina "movimientismo", se revela en las expectativas irrealistas depositadas en la política, que ya no responden tanto a una perspectiva de intereses colectivos sino más bien a intereses individuales. Ver "Democracy by Default; Economic Crisis, Movimientism and Social Anomia en latin America".

$88 \mathrm{Tal}$ vez no sea casual que el sentimiento de individualización trágica en la literatura latinoamericana tenga su mayor expresión en la obra de Juan Carlos Onetti, autor cuyo país de origen, Uruguay, presenta características socioculturales muy próximas a los países centrales.
} 


\section{Conclusiones}

\section{¿Política sin moral y moral sin política?}

Vivimos en un período en que las categorías sociales consideradas como centrales en la historia contemporánea se encuentran en rápida mutación. La oposición trabajadores/pueblo versus capitalistas/elites, sobre la cual se construyeran las identidades y conflictos sociales en el capitalismo industrial, se está diluyendo o está siendo substituida por identidades/oposiciones fragmentadas y fragmentadoras de la vida social. Etnias, género y religiones son algunas de las múltiples identidades a partir de las cuales se constituye hoy la percepción de sí mismo y del otro, cuyas reivindicaciones no remiten a la reconstrucción de la sociedad sino a la defensa de mundos específicos.

Las clases sociales - ciertamente los actores colectivos fundamentales del siglo XX perdieron su centralidad. O sea, la lucha de clases y las ideologías a ella asociadas entraron en declinación, y nada parece indicar un renacimiento de esas categorías sociales. Sin embargo, la política continúa y el desafio de las ciencias sociales es descifrar su lógica.

Como vimos al inicio de este libro, la ciudadanía moderna construyó simultáneamente la noción de individuos libres e iguales y de com unidad nacional. La ciudadanía supuso individuos vinculados por valores comunes y por proyectos trazados para el conjunto de la sociedad, más allá de que estos últimos pudieran ser diferentes y conflictivos. Sin embargo, el individualismo y la creciente fragmentación simbólica causada por la valorización de culturas étnicas y/o religiosas, tendi entes a considerar las lealtades y los valores personales y/o grupales como prioritarios y no negociables, ponen en jaque la noción republicana de espacio público y bien común.

Esta mutación implica una transformación del lenguaje y de las organizaciones políticas. En lugar de partidos políticos consagrados a expresar visiones inclusivas de la sociedad, tenemos una fragmentación de la representación social, acompanada de una fragmentación de las identidades. Los nuevos portavoces de valores y mini-utopías son las ONGs, cuya multiplicación acompana la desintegración de las grandes ideologías. Los partidos políticos, aunque insustituibles todavía como mecanismo político-institucional de representación, parecen condenados a transformarse en conglomerados amorfos sin densidad moral, encuadrados por el movimiento de un mundo social cuyos parámetros y dinámica ya no comprenden.

El discurso de los derechos humanos es hoy la lengua franca de la globalización. Sus constructores son ONGs e instituciones internacionales (en particular el sistema de las Naciones 
Unidas) y sus más importantes fuentes de financiación son agencias internacionales, fundaciones norteamericanas, instituciones filantrópicas y gobiernos europeos. Los intelectuales de esa nueva ideología constituyen una mezcla de activistas sociales y de tecnócratas que se mueven a escala internacional, apoyados por periodistas y personalidades mediáticas. En este contexto, los ideólogos de los partidos políticos nacionales se transformaron en intelectuales provincianos, responsables de la administración del pequeno mundo local y de su adaptación a las realidades de la globalización.

La paradoja democrática se manifiesta en el debilitamiento de la democracia política, no por un déficit de valores democráticos, sino, al contrario, por la profundización de las expectativas igualitarias. Los valores democráticos de una sociedad que procura ser transparente e igualitaria producen desconfianza respecto a la moralidad de los políticos y a la opacidad del Estado, junto a una creciente frustración con respecto a los partidos políticos y a un sentimiento de que los gobiernos democráticos son incapaces de enfrentar los problemas de igualdad social o de la violencia. En otras palabras, el conflicto entre las expectativas producidas por la cultura democrática y la realidad político-institucional se manifiesta a través de una pérdida de confianza en la propia democracia como régimen político.

Mientras en el período anterior, las innovaciones sociales eran traducidas e incorporadas dentro de los grandes marcos ideológicos, los derechos humanos funcionan, en cambio, mediante fragmentación y expansión permanente. Cada nuevo grupo o cada nueva percepción de la sociedad se asocia a la defensa de un nuevo derecho (derecho de la mujer, de los ninos, de los negros, de las minorías, de las animales; derecho a la salud, a la información, al desarrollo; derecho ambiental, entre otros).

Si los derechos humanos todo lo absorben, el conflicto social pasa a girar en torno a la interpretación de esos derechos, terreno en el cual hoy se confrontan dos grandes versiones. La primera, ciertamente asociada a una visión etnocéntrica, reivindica un núeleo esencial de derechos humanos (fundamentalmente los derechos que aseguran la libertad individual), en tanto portadores de una visión superior del mundo, anelados en el núcleo sagrado de la "cultura occidental". Tal perspectiva está profundamente enralzada en el mundo anglosajón y es hoy dominante en los Estados Unidos. La segunda visión, asociada a la experiencia del trauma pos-colonial, diseminada en las últimas décadas por Europa continental, incluye entre los derechos la diversidad cultural, lo que implica enfatizar la tolerancia hacia los grupos sociales, los cuales por cierto no practican - o aún discrepan con - los valores asociados alos derechos humanos.

Ambas perspectivas, como acontece en general con todas las visiones del mundo, se ven enfrentadas a los problemas teóricos de inclusividad y coherencia. Asi, la visión etnocéntrica corre el riesgo constante de deshumanizar todo lo que no se someta a su percepción de la humanidad, 
mientras que la perspectiva multicultural de los derechos humanos termina igualando todas las culturas, disminuyendo la capacidad de autodefensa y de lucha por los valores propios.

\section{Los desafios a la democracia}

La modernidad rompe con todas las formas de sociedad que la antecedieron al dejar de percibir en el orden social un destino predeterminado por una fuerza trascendental y exterior a la voluntad de los hombres. En el mundo moderno, el individuo y la sociedad están condenados a autoproducirse, a inventar el futuro. Sólo en la modernidad el individuo y la sociedad vinieron a autorepresentarse como entes autónomos frente a otras esferas de la vida social (en particular la religión), lo que permitió el surgimiento de nuevas disciplinas cognitivas, como la sociologia y la psicologia.

La autoproducción del individuo y de la sociedad dio lugar a una serie de derechos, de instituciones y de ideologias, que contribuyeron a que los modernos se volvieran productores de su futuro. Las ideologias políticas fueron, durante los siglos XIX y XX, el vector por el cual el destino colectivo de la "sociedad" fue proyectado hacia el futuro. Esas ideologias políticas entraron en crisis en razón del descreimiento en el progreso, en la posibilidad de prever el futuro de la sociedad o en la probabilidad de que ella pueda ser modelada por proyectos políticos realizados desde el poder del Estado.

El desencuentro entre la política y la sociedad llevó alos activistas sociales e intelectuales a procurar nuevos marcos conceptuales y formas de organización que permitan actuar y pensar las nuevas formas de autoproducción de la sociedad. Lo cual ha generado, como ya vimos, la valorización de categorías como la "sociedad civil" y el desarrollo de ONGs, cuyo principal efecto ha sido la disociación entre política y moral, entendida la política como participación en la esfera pública con el objetivo de gobernar y/o transformar el Estado. El discurso de los derechos humanos disoció además los nuevos discursos transnacionales de las estructuras de sustentación institucional de la sociedad, aún encuadradas en los estados nacionales ${ }^{89}$. Tal disociación afecta en particular a los partidos políticos, transformados en productores de cuadros administrativos, cuya fuente de legitimidad remite fundamentalmente a la capacidad de producir estabilidad financiera $\mathrm{y}$ crecimiento económico.

La nueva ideología política dejó de auto-presentarse como política ${ }^{90}$. Ella se vislumbra como una visión moral, sustentada en valores extraídos del discurso de los derechos humanos o de

\footnotetext{
${ }^{89}$ Ver el libro de Michaellgnatieff, Human Rights as Politics and Indolatry, que analiza los derechos humanos en la esfera de las relaciones intemacionales. 90 Ver Richard Rorty, Achieving our Country.
} 
la religión. La disociación entre moral y política, en razón de la pérdida creciente de legitimidad del Estado como fuente generadora de valores, así como el dislocamiento del conflicto social hacia el Poder judicial han llevado a los pensadores sociales contemporáneos a transferir el foco de reflexión sobre la sociedad, desviando el análisis del poder del Estado hacia la producción de derechos.

En un mundo en que el individualismo triunfante está acompaflado por una creciente desigualdad social y por síntomas de desintegración de los lazos de solidaridad social, el debate en el seno de la tradición liberal se dislocó, en particular, hacia la cuestión de la justicia en una sociedad individualista (la obra de Rawls ocupa en este sentido un lugar central), hacia el papel del Poder Judicial (en donde sobresalen los trabajos de Ronald Dworkin) y hacia las posibilidades de manutención de formas comunitarias de organización social en un orden libera ${ }^{91}$.

En la tradición socialista, por razones obvias, la crisis es mucho más profunda, pues és ta sufre dos grandes dislocamientos: por un lado, el fin de la creencia en la centralidad de la clase obrera y de su potencial para crear una nueva sociedad; por otr.o, los sectores que hoy aparecen como las principales "víctimas" del capitalismo no son los explotados por el sistema sino los excluidos del mismo, los desempleados crónicos, los "inempleables".

Para los partidos socialistas de masas el desafío pasó a ser el de presentar programas capaces de incluir los nuevos sectores medios y los valores de las nuevas formas de gestión de la administración pública, originados en el sector privado - como eficiencia, competitividad, disciplina fiscal - expresando una mayor sensibilidad ante los problemas de desigualdad social. La respuesta intelectualmente más elaborada a ese desafio ha sido la llamada "tercera vía", la cual enfatiza la utilización de políticas públicas para asegurar un mínimo de servidos sociales que limiten la exclusión social y la degradación de los sectores más pobres de la población ${ }^{92}$. Pero si la "tercera vía" reconoce que corresponde al Estado intervenir de forma compensatoria, concuerda en que se debe disminuir, en lo posible, toda intervención reguladora en el mercado de trabajo. Esta postura es particularmente sensible a las reivindicaciones identitarias, espacio en el que sería posible el desarrollo de políticas de reconocimiento simbólico sin mayores costos económicos ni perjuicios relevantes al funcionamiento del mercado.

La "tercera vía" fue presentada, hasta ahora, como la única propu esta capaz de ser una alternativa viable de izquierda en el contexto del nuevo capitalismo globalizado, capaz de apostar al mundo de los "ganadores" sin abandonar completamente los valores de solidaridad y de justicia social, esto es, sin dejar de atender la situación de los "perdedores". En qué medida es posible, sin

\footnotetext{
91 Ver, en particular, John Rawls, A Theory of Justice; Ronald Dworkin, Los derechos en serio. En la extensa bibliografia sobre el comunitarismo puede consultarse una sintesis de los debates en Amy Gutmann, Multiculturalism; Amital Etzioni, New Communitarian Thinking; Nathan Glazer, Affirmative Discrimination. 92 Ver Anthony Giddens, Para além da esquerda e da direita.
} 
embargo, mantener al Estado como un instrumento compensador de justicia social, mientras se permite al "mercado" aumentar la desigualdad social o destruir derechos sociales adquiridos (como, entre otros, la limitación del horario de trabajo, las vacaciones, la jubilación, el derechomaternidad), es una cuestión, por decir lo menos, aún abierta.

En confrontación con la tercera vía, se han venido desplegando esfuerzos, todavía embrionarios, de reconstitución de la teoría revolucionaria extraparlamentaria, asociados alos nuevos foros de lucha antiglobalización. Sefial de los tiempos: la reflexión se ha venido orientando en dirección a un análisis crítico del orden jurídico. En este sentido sobresale, en particular, la obra de Antonio Negri, ${ }^{93}$ orientada a revertir los límites del orden social acudiendo a la valorización del poder constituyente frente a las formas legales que procuran domesticado o disciplinarlo. A su vez, otras tendencias han pretendido criticar el orden social mediante la valorización del pluralismo jurídico ${ }^{94}$, invocando la fragmentación creciente del orden jurídico en términos supra y subnacionales, enfatizando la constitución de nuevos espacios de solidaridad orientados por valores alternativos ${ }^{95}$.

Nada indica que los caminos apuntados representen una salida convincente para la reconstitución del orden social. El ejercicio permanente del "poder constituyente" de Negri va en contra de todo el conocimiento sociológico respecto a la tendencia de las sociedades a organizar y ordenar la vida social, y se fundamenta en una visión bastante personal del autor sobre Ia condición humana y la libertado En cuanto a la valorización del "pluralismo jurídico" desconoce que buena parte de las nuevas formas de regulación legal extra-estatal es realizada por criminales o es el producto de una carencia de servicios estatales adecuados más que la expresión de formas superiores de ordenamiento jurídico (como ocurre, por ejemplo, en las favelas).

Ciertamente, estas perspectivas expresan un fenómeno real: la crisis de la ciudadanía, tal como se cristalizara en el siglo XX. La ciudadanía es el mecanismo institucional por el cual, en las sociedades democráticas modernas, el orden jurídico articula las relaciones entre ella misma, la sociedad y el Estado. Sin embargo, los componentes de esa ecuación registran hoy enormes modificaciones. La "sociedad", en cuanto conjunto humano identificable empírica y subjetivamente con una población delimitada por las fronteras nacionales, ha perdido densidad - ya sea por los procesos de globalización, ya sea por las nuevas identidades colectivas que no tienen como referencia el marco nacional. El Estado, pese a mantener una función central en la regulación social, ha visto disminuida su legitimidad debido al debilitamiento de la representación partidaria o de la

\footnotetext{
${ }^{93}$ Antonio Negri, O poder constituinte.

94 Sobre el pluralismo juridico existe una amplia bibliografia; ver Jean Carbonier, Sociologie juridique. Para el debate sobre la utilización del caso brasileño, ver Eliane Botelho Junqueira, A sociologia do dereito no Brasil. 95 Ver en particular Boaventura de Souza Santos, Toward a New Common Sense.
} 
lealtad a la patria/nación/pueblo, sin contar el sentimiento reinante de que gobernar se transformó en una práctica tecnocrática al servicio de las exigencias de los mercados. Finalmente, el propio derecho ha visto afectado su campo de acción tanto por la influencia de la constitucionalización del sistema legal y del impacto de los derechos humanos en la práctica jurídica, como por Ia expansión del campo del derecho a nuevos sujetos y la juridicionalización del conflicto social.

Como principal vector de la participación y la representación política, la ciudadanía entró en crisis, poniendo en evidencia las dificultades crecientes de comunicación entre los diferentes subsistemas sociales y el Estado. Como vimos, las nuevas identidades colectivas y los actores sociales a ellas asociados, cuyas filiaciones remiten a redes que operan en los dominios sub o supraestatal $^{96}$, no pretenden llegar al gobiemo y sus agendas son, en general, transnacionales. En la medida que el sistema judicial absorbe esa nueva realidad, debe aceptar el desacoplamiento entre el orden estatal nacional y el orden jurídico, lo que implica, en última instancia, una disociación entre ciudadanía y orden jurídico nacional. Igualmente, la construcción de nuevos actores sociales en tomo a identidades sociales que esencializan sus diferencias importa el riesgo de destrucción del espacio público, el cual supone compartir un sustrato de valores comunes, comenzando por la creencia en que el diálogo establecido en la esfera pública es productivo, es decir, transforma los actores que participan en él, tiene un valor sustantivo y no se reduce a un mero campo de negociación de intereses o visiones particularistas.

Tal vez la principal contradicción de la vida política en el mundo contemporáneo sea la de la globalización de las agendas políticas frente a la persistente realidad del Estado nacional como locus central de generación y distribución de riqueza. La globalización de agendas vale tanto para aquéllos que apoyan las políticas llamadas neoliberales como para los que se oponen a ellas. La diferencia es que, mientras los que asumen la globalización como un hecho positivo sustentan una agenda basada en la promoción dellibre mercado, sus oponentes apoyan la promoción de derechos humanos (cuyo número, como vimos, se expande vertiginosamente).

La tendencia hacia agendas globales y a posiciones orientadas a dar la espalda al Estado, crea un espacio para que aventureros políticos populistas o de extrema derecha reivindiquen la representación y la defensa de la nación. Teniendo en cuenta tales tendencias, este trabajo apunta a la necesidad de ir más allá de las agendas globalizadas y enfatiza la urgencia de elaborar estrategias institucionales nacionales que incorporen, sin reluctancia, el contexto de globalización, actuando sobre él, fortaleciendo el Estado como instrumento democrático de regulación y control del poder económico, reinventando los instrumentos de planificación social y del derecho laboral,

\footnotetext{
${ }^{96}$ Ver Manuel Castells, The Rise of The Network Society.
} 
reunificando, de forma creativa, en fin, los derechos individuales y colectivos, aun cuando esto resulte de la movilización de auto-intereses bien informados, pues es imposible construir paraísos en infiernos sociales. Ese desafío exige el abandono de la actitud de pensar los procesos de globalización como si fuesen un fenómeno esquizofrénico: con un lado malo a ser eliminado y otro bueno a ser cultivado. Más bien debemos tener presente que, en el capitalismo, la lex mercatoria siempre desempeñió un papel de vanguardia, y que corresponde a las fuerzas sociales aprovechar el impulso transformador del capital para que su imperio sea delimitado y su impacto humanizado. 


\section{Anexo}

\section{Nota sobre interdisciplinariedad}

Este libro refleja nuestra plena conciencia en la necesidad y los límites de la interdisciplinariedad, la cual constituye, en cierta forma, una utopia de las ciencias sociales. Existe un cierto consenso en torno a la idea de que para entender la complejidad de la vida social es necesario movilizar los recursos de varias disciplinas, pues cada una de ellas es capaz de reflexionar exclusivamente sobre una dimensión parcial de la sociedad. Con todo, cuando la utópica obra interdisciplinaria se concretiza, las resultados se sitúan más acá de las expectativas, acotándose a una especie de bricolage, en el que las diferentes disciplinas son movilizadas ad hoc para cubrir las lagunas de las otras, obteniéndose, en el mejor de los casos, una obra prima irreproducible pues se trata, en definitiva, del producto único de la capacidad de sintesis o de erudición del autor. Así, si las estudios disciplinarios son, en gran medida, redundantes, pues sus largos argumentos sólo sirven para confirmar las premisas iniciales, los trabajos interdisciplinarios son generalmente entrópicos, es decir, irreproducibles, ya que no poseen consistencia teórica, ni ofrecen efectivas posibilidades de comparación o de acumulación intelectual.

La dificultad de la interdisciplinariedad es doble, pues la especialización es expresión tanto de la realidad de las sociedades modernas, en las cuales los subsistemas sociales están altamente diferenciados, como de la diversidad de disciplinas que estudian los diferentes subsistemas, y que desarrollan teorias, conceptos, problemáticas y - aún más importantesistemas auto referidos de discursos que hacen que el pasaje de un marco disciplinario a otro sea cuestionable.

El problema central de la interdisciplinariedad no reside en que cada disciplina de Ias ciencias sociales posea una vocación imperial y, por tanto, una natural tendencia invasora, irrespetuosa o, como suele ocurrir, insensible a la especificidad de las diferentes lógicas teóricas y prácticas de cada disciplina, sino en el hecho de que, en una sociedad democrática, la autonomía de los subsistemas sociales es la condición del pluralismo intelectual, de la libertad individual y colectiva o bien es el fundamento de un sistema de justicia no sometido a Ia tiranía del poder económico, político, cognitivo o religioso. En este sentido, todo sistema explicativo que procure reducir el Derecho (o cualquier otro subsistema social, como, por ejemplo, la investigación Científica) a causas exógenas, como, por ejemplo, a intereses económicos o a algún otro factor externo, participa, conscientemente o no, de un esfuerzo de deslegitimación de las instituciones democráticas.

En la América Latina contemporánea, el sentimiento de urgencia producido por la 
desigualdad y los enormes problemas sociales continúan induciendo a muchos sectores deseosos de cambios a una voluntad transformadora, desconocedora de los procedimientos legales y de las exigencias propias de la lógica jurídica. De esta forma, tales grupos se aproximan, siguiendo su propio camino, a la tendencia, arralgada en la historia del continente, de violación de la autonomía de las esferas de la justicia, tendencia que ignora que la autonomía de los sujetos en la sociedad moderna sólo puede ser construi da a partir del reconocimiento y el respeto a las reglas propias de cada subsistema social.

Si decidimos emprender el esfuerzo de un análisis interdisciplinario partiendo del reconocimiento de tales dificultades, es porque creemos que la dinámica social impone hoy el diálogo entre las disciplinas. Ese diálogo debe reflejar y operar sobre una realidad en la cuallas fronteras entre el sistema jurídico y los otros subsistemas sociales tienden, si no a difuminarse, por lo menos a dar claras seftales de innumerables rajaduras y tensiones. 


\section{Referencias Bibliográficas}

ALBERTI, Giorgio, "Democracy by default, economic crisis, movimientismo and social anomie in Latin America", Trabajo preparado para presentación en el XV World Congress of the Intemational Political Science Association, Buenos Aires, 1991.

APPADURAL, Arjun, The Social Life of Things, Cambridge, University Press, 1996.

ARANTES, Rogério B., Judiciário e política no Brasil, São Paulo, Sumaré, 1997.

ARATO, Andrew, "Além da dicotomia Estado/Mercado", Novos Estudos CEBRAP, n.36, 1993.

"Uma reconstituição hegeliana da sociedade civil", in AVRITZER, Leo, (ed.), Sociedade civil e democratização, Belo Horizonte, Del Rey, 1994.

BAUDR1LLARD, Jean, Le systême des objets, Paris, Gallimard, 1968.

BAUMAM, Zygmunt, Legislators and Interpreters: on Modernity, Postmodernity, and the Intellectuals, Oxford, Polity Press, 1987.

. Intimations of Postmodernity, London, Routledge, 1992

. Life in Fragments, Oxford, Blackwell, 1995.

. O Mal-estar da pós-modernidade, Rio de Janeiro, Jorge Zahar, 1999.

BECK, Ulrich, What is Globalization?, Oxford, Blackwell, 2000.

BOBBIO, Norberto, O conceito de sociedade civil, Rio de Janeiro, Graal, 1982.

. A era dos direitos, Rio de Janeiro, Campus, 1992.

BOBBIT, Phillip, The Shield of Achilles: War, Peace and the Course of History, London, Penguin, 2002.

BOROUMAND, Ladan, La guerre des principes. Paris, Editions de L École des Hautes Études en Sciences Sociales, 1999.

BULMER, Martin and Anthony M. REES (orgs.), Citizenship Today: the Contemporary Relevance of T. H. Marshall, London, UCL Press, 1996.

CARBONNIER, Jean, Sociologie juridique. Paris, PUF, 1978.

CASTEL, Robert; Claudine HAROCHE, Propriété privée, propriété sociale, propriété de soi, Paris, Fayard, 2001.

CASTELLS, Manuel, The Rise of the Network Society, Oxford, Blackwell, 1996.

COHEN, Jean and Andrew ARATO, Civil Society and Poltical Theory, Cambridge, MIT Press, 1997

COLEMAN, James M., Foundations of Social Theory, Cambridge, Harvard University Press, 1990.

CORTEN, Olivier e Patricio NOLASCO, "Pluralism culturel, pluralism juridique et démocratie: les ambigúites du discours identitalre zapatiste", Les Cahiers du GELA.1S n.1, 2001.

COSTA, Sérgio, "A construção da raça no Brasil", ms.

. As Cores de Ercília. Belo Horizonte, UFMG, 2002.

DEZALAY, Yvez, GARTH, Bryant G., The Internationalization of Palace Wars: Lawyers, Economists, and the Contest to Transform Latin American States, Chicago, The University of Chicago Press, 2002. 
DOMINGUES, José Maurício, "A dialética da modernização conservadora e a nova história do Brasil", DADOS, n.3, v.45, p.459-482, 2002.

DOUGLAS, Mary e Baron ISHERWOOD, The World of Goods, London, Routledge, 1996.

DWORKIN, Ronald, Los derechos en serio, Barcelona, Ariel, 1999.

EHRENBERG, Alain, La fatigue d'être soi, Paris, Odile Jacob, 1998.

ETZIONI, Amital, New Communitarian Thinking, Charlottesville, The University Press of Virginia, 1996.

EWALD, François, Histoire de l'état providence, Paris, Grasset, 1986.

FEATHERSTONE, Mike. Consumer, Culture \& Postmodernism, London, Sage, 1990

FERNANDES, Rubem César, "Threads of Planetary Citizenship", in OLIVEIRA, Miguel D. e Rajesh TANDON (orgs.). Citizens-Strengtheningglobal civil society. Washington, Civicus, 1994.

FERRY, Luc; Alaln RENAUT, Philosophie politique: des droits de l'homme à l'idée républicaine. Paris, PUF, 1985.

FRASER, Nancy, "Da redistribuição ao reconhecimento? Dilemas da justiça na era pós socialista", in SOUZA, J. (org.). Democracia hoje: novos desafios para a teoria democrática contemporánea. Brasília, UnB, 2001.

FROMM, Erich, Scape from freedom, New York, Henry Holt, 1995.

GABRIEL, Yannis and Tim LANG, The Unmanageable Consumer, London, Sage, 1995

GAUCHET, Marcel, "Essal de psychologie contemporalne", Le Débat, n.99 e 100, 1998.

La religion dans la démocratie: parcours de la lalcité. Paris, Gallimard, 1998.

. "Quand les droits de l'homme deviennent une politique", Le Debat, n.110, mal-out, 2000.

GIDDENS, Anthony, Para além da esquerda e da direita, São Paulo, Unesp, 1995.

and Scott LASH. Reflexive Modernization, Stanford, Stanford University Press, 1994

GLAZER, Nathan, Affirmative Discrimination: Ethnic Inequality and Public Policy. Cambridge, Harvard University Press, 1987.

GROS, Christian, Políticas de la etnicidad: identidad, estado y modernidad, Bogotá, ARFO, 2000.

HABERMAS, Jürgen, The Theory of Communicative Action, Boston, Beacon Press,

1989.

"Struggles for Recognition in the Democratic Constitutional State", in GUTMANN, Amy. Multiculturalism, Nova Jérsei, Princeton University Press, 1994.

HIRSCHMAN, Albert, Saída, voz e lealdade. São Paulo, Perspectiva, 1970.

HUNTINGTON, Samuel, Political Order in Changing Societies, London, Yale University Press, 1969.

IGNATIEFF, Michael. Human Rights as Politics and Indolatry, Princeton, Princeton, 2002.

JUNQUEIRA, Eliane B., A sociologia do direito no Brasil, Rio de Janeiro, LumenJuris, 1993.

KAGAN, Robert, Of paradise and power: America and Europe in the new world order, New York, Knof, 2003.

LASCH, Christopher, The Minimal Self: Psychic Survival in Troubled Times, New York, Norton, 
1984.

LEFORT, Claude, l'invention democratique: les limits de la dominiation totalitaire, Paris, Fayard,1981.

LUHMANN, Niklas, "La restitution du douziéme chameau: du sens de'une analyse sociologique du droit", Droit et Societé, n.47, 2001.

MACPHERSON, C. B., The Political Theory of Possessive Individualism, Oxford, Oxford U.O., 1962.

MANN, Michael, "Ruling Class Strategies and Citizenship", Sociology, vol. 21, n. 3, 1987.

MARSHALL, T. H., Citizenship and social dass and other essays. Cambridge, Cambridge University Press, 1950.

MARTUCCELLI, Danilo, "Del espejo opaco alos riesgos de la transparencia invisible:

notas sobre la teoria social", ms., 2002.

. Dominations ordinaries, Paris, Balland, 2002.

. Grammaires de l'individu. Paris, Gallimard, 2002.

MARX, Karl, El Capital, VI, Buenos Aires, Cartago, 1973.

McCRACKEN, Grant. Culture \& consumption, Bloomington, Indiana University Press, 1990.

MILLER, Daniel (org.), Acknowledging Consumption, London, Routledge, 1996.

NEGRI, Antonio, O poder constituinte, Rio de Janeiro, OP\&A, 2002.

NEVES, Marcelo, "Et si le douziéme chameau venalt à manquer? Ou droit expropiateur au droit envahi", Droit et Societé, n.47, 2001.

PERALVA, Angelina, Violência e democracia, São Paulo, Paz e Terra, 2000.

PIORE, Michael P, Beyond Individualism, Cambridge, Harvard University Press, 1995.

PUTNAM, Robert O., Making Democracy Work, New Jersey, Princeton University Press, 1993.

RAWLS, John, A Theory of Justice, Cambridge, Harvard University Press, 1971.

RORTY, Richard, Achieving our country: Leftist thought in twentieth-century America, Cambridge, Harvard University Press, 1998.

ROSANVALLON, Pierre, La crise de l'état-providence. Paris, Seuil, 1984.

. La nouvelle question sociale, Paris, Seuil, 1995.

SALAMAN, Lester M. et al., La Sociedad Civil Global: las dimensiones del sator no lucrativo, Bilbao, Fundación BBVA, 1999.

SANTOS, Boaventura Souza, Toward a New Common Sense, London, Routledge, 1995.

SANTOS, Wanderley Guilherme dos, Cidadania e justiça: a política social na orden brasileira, Rio de Janeiro, Campus, 1979.

SCHNAPPER, Dominique, La communauté des citoyens, Paris, Gallimard, 1994.

SIMMELS, Georg, The Philosophy of Money, London, Routledge, 1991.

SLATER, Don, Consumer, Culture \& Modernity, Cambridge, Polity Press, 1997

SORJ, Bernardo, "Crises e horizontes das ciências socials na América Latina", Novos Estudos 
Cebrap, n.23, p.154-163, 1989.

A nova sociedade brasileira, Rio de Janeiro, Jorge Zahar, 2000.

. A construção intelectual do Brasil contemporâneo, Rio de Janeiro, Jorge Zahar, 2001.

"La relación público/privado en el Brasil", in WOLF, L.; GONZALEZ, P e NAVARRO, J. C., Educación privada y política pública en América Latina. Santiago de Chile, PreallBID, 2002, p.143-184.

. brazil@digitaldivide.com: Confronting Inequality in the Information Society-, Brasília, /UNESCO, 2003.

SOUZA, Jessé (org.), O Malandro e o Protestante. Brasília, UnB, 1999.

SULKUNEN, Pekka, John HOLMWOOD, Hilary RADNER and Gerhard SCHULZE (orgs.), Constructing the New Consumer Society, London, Macmillan, 1997.

SUPIOT, Alain, Critique du droit du travall. Paris, PUF, 1994.

SVAMPA, MaristeIla, El dilema argentino: civilización o barbarie, Buenos Alres, El cielo porasalto, 1994.

TERRADAS, Ignaci, "Familia y ciudadanía en Ia Revolución Francesa". Barcelona, M.S., 1997.

TORRE, Juan Carlos, El processo político de las reformas económicas en América Latina, Buenos Alres, Paídós, 1998.

TOURAINE, Alain, Critique de la modernité. Paris, Fayard, 1992.

. "O campo político de FHC", Tempo Social. V 12, n.1, p.3-22, malo, 2000.

TURNER, Bryan S., "Outline of a Theory of Citizenship", Sociology, v.21, n.3, 1987.

VIANNA, Luiz Werneck et al., Corpo e alma da magistratura brasileira, Rio de Janeiro, Revan/Iuperj, 1997.

WALZER, Michael, Spheres of Justice. Oxford, Martin Robertson, 1983.

"Multiculturalism and the Politics ofInterest", in BIALE, David, Michael GALCHINSKY e Susannah HESCHEL (orgs.), Insider/Outsider, American Jews and multiculturalism, Berkeley, University of California Press, 1998, p.89.

www.worldbank.org/civilsociety

www.worldbank.org/wbp/scapital

www.worldbank.org/wbp/scapital/topic 